\title{
Final Project Report for Material Security and Consolidation Project
}

\section{Project Number: 08-D-702}

May 2013

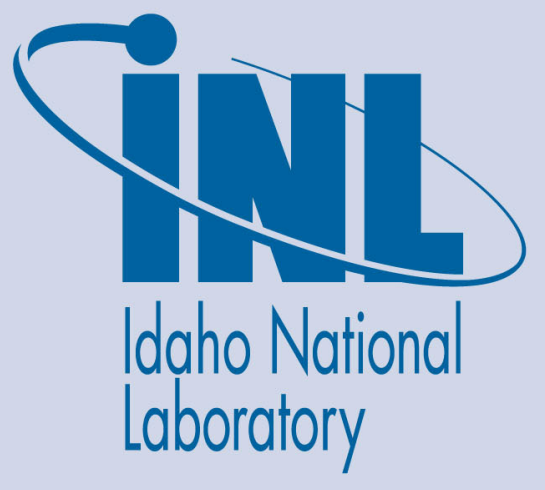

The INL is a U.S. Department of Energy National Laboratory operated by Battelle Energy Alliance 
INL/EXT-13-29125

\section{Final Project Report for Material Security and Consolidation Project}

Project Number: 08-D-702

May 2013

\section{Idaho National Laboratory \\ Idaho Falls, Idaho 83415}

http://www.inl.gov

Prepared for the

U.S. Department of Energy

Office of Nuclear Energy

Under DOE Idaho Operations Office

Contract DE-AC07-05ID14517 


\section{DISCLAIMER}

This information was prepared as an account of work sponsored by an agency of the U.S. Government. Neither the U.S. Government nor any agency thereof, nor any of their employees, makes any warranty, expressed or implied, or assumes any legal liability or responsibility for the accuracy, completeness, or usefulness, of any information, apparatus, product, or process disclosed, or represents that its use would not infringe privately owned rights. References herein to any specific commercial product, process, or service by trade name, trade mark, manufacturer, or otherwise, does not necessarily constitute or imply its endorsement, recommendation, or favoring by the U.S. Government or any agency thereof. The views and opinions of authors expressed herein do not necessarily state or reflect those of the U.S. Government or any agency thereof. 



\section{EXECUTIVE SUMMARY}

The Idaho National Laboratory's missions related to nuclear energy technologies within the Department of Energy's Office of Nuclear Energy continue to grow. Additional onsite storage to support planned disposition activities for sodium-bonded spent fuel is essential to consolidate the Idaho National Laboratory's inventory of spent nuclear fuel as required to support the 1995 Settlement Agreement between the State of Idaho and the Department of Energy.

The Material Security and Consolidation Project has modified and upgraded building CPP-651 at the Idaho Nuclear Technology and Engineering Center to provide storage of low-enriched uranium (LEU), up to and including Hazard Category II quantities of nuclear material. This LEU is disposition product from the processing of sodium-bonded spent fuel. It currently is stored in the Transient Reactor Experiment and Test Facility warehouse.

Modifications to CPP-651 and the surrounding area included installation of a perimeter security fence, additional security features, LEU handling equipment, a new security door, a new crane in the north storage vault, and a new facility entry vestibule. CPP-651 is not a fully occupied facility and has the primary function of being a storage facility for nuclear material. 


\section{CONTENTS}

EXECUTIVE SUMMARY iii

ACRONYMS vii

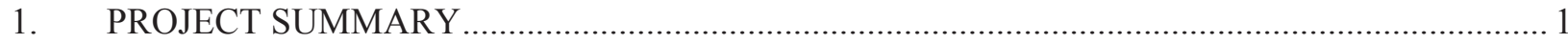

2. SUMMARY OF THE FINAL PROJECT SCOPE AND DELIVERABLES …............................ 1

2.1 Technical, Cost, and Schedule Baseline Accomplishments ............................................... 3

2.2 Significant Changes to the Project Baseline ................................................................... 3

2.3 Identified Opportunities for Related New Business or Technical Transfer .......................... 3

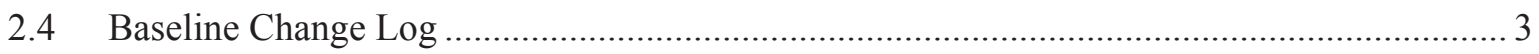

3. OPEN ITEMS REQUIRED IN ORDER TO COMPLETE THE PROJECT …................................ 3

4. PERMITS, LICENSES, ENVIRONMENTAL DOCUMENTATION, WARRANTIES,

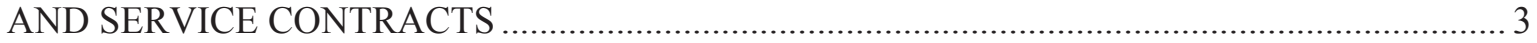

4.1 Permits, Licenses, Environmental Documentation Generated ............................................. 4

4.2 Warranties and Service Contracts Maintained by the Customer/Facility Manager or

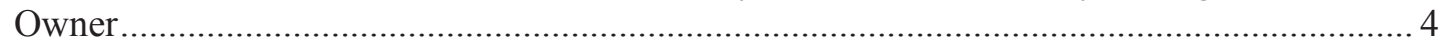

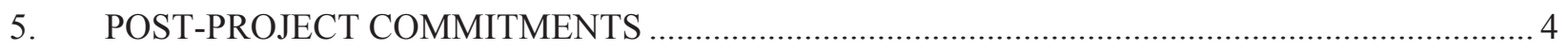

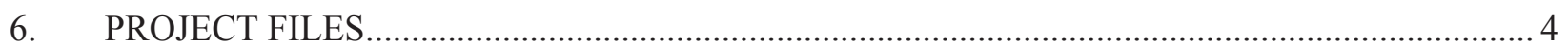

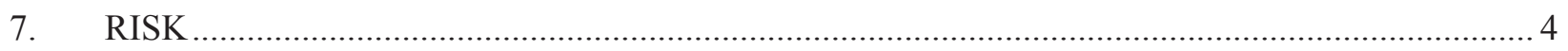

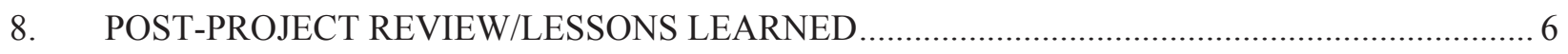

9. FINAL COST REPORT AND FINANCIAL CLOSEOUT STATUS ….................................... 6

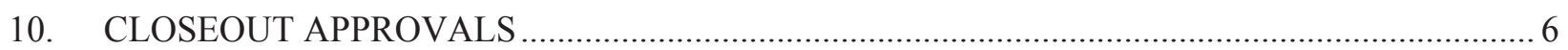

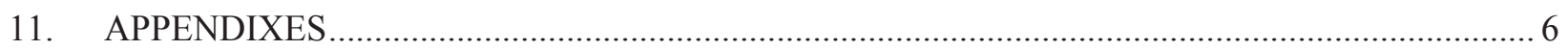

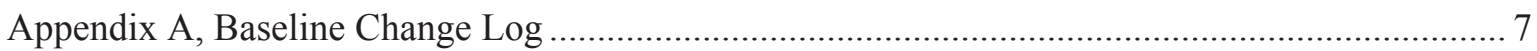

Appendix B, Warranty Information and Service Contracts......................................................... 11

Appendix C, Post Project Review/Lessons Learned Report ..................................................... 23

Appendix D, Design Phase Post-Project Review/ Lessons Learned Report .................................. 33 
Appendix E, Executed Transition to Operations Plan

Appendix F, Cost Closing Statement ..... 


\section{ACRONYMS}

BEA Battelle Energy Alliance, LLC

CD critical decision

DOE Department of Energy

DSA documented safety analysis

INL Idaho National Laboratory

LEU low-enriched uranium

MSCP Material Security and Consolidation Project

UPS uninterruptible power supply 


\section{Final Project Report for Material Security and Consolidation Project}

\section{PROJECT SUMMARY}

As stated in the approved U.S. Department of Energy (DOE) project execution plan, the Idaho National Laboratory's (INL's) missions related to nuclear energy technologies within the DOE Office of Nuclear Energy continue to grow. Additional onsite storage to support planned disposition activities for sodium-bonded spent fuel is now essential to consolidate the site's inventory of spent nuclear fuel as required to support the 1995 Settlement Agreement between the State of Idaho and DOE.

The Material Security and Consolidation Project (MSCP) was the preferred alternative, as approved by Critical Decision (CD)-1, to the specific need for additional onsite storage for sodium-bonded spent fuel disposition, which is considered to be low-enriched uranium (LEU). This project met the mission need for additional storage of the LEU disposition product from processing of sodium-bonded spent fuel to be stored in the CPP-651 facility at the Idaho Nuclear Technology and Engineering Center. This LEU currently is stored in the Transient Reactor Experiment and Test Facility warehouse. Starting in Fiscal Year 2010, the disposition activities increased into production levels. Current INL storage locations were limited to accommodate this increased production without impacting ongoing missions. The refurbishment of CPP-651 supports a nuclear material storage location to accommodate this LEU. Modifications were made to CPP-651 to provide storage of the LEU.

Modifications to CPP-651 and the surrounding area include installation of a perimeter fence, additional security features, LEU handling equipment, a new security door that provides an additional building egress route, new fire protection sprinkler systems and alarms, a new crane and storage racks in the north vault, and a new facility entry vestibule. CPP-651 is not a fully occupied facility and has the primary function of being a storage facility for nuclear material.

\section{SUMMARY OF THE FINAL PROJECT SCOPE AND DELIVERABLES}

The project scope included updating the documented safety analysis (DSA) and completion of construction work, documentation of construction, implementation of the safety basis into operating procedures, completion of readiness assessments, and submittal of project closeout paperwork (CD-4). A summary of the work is provided as follows:

- Updating the DSA:

- $\quad$ The DSA was updated and implemented to be compliant with 10 CFR 830.

- Construction work:

- Modifications to CPP-651 (as described in Section 1) to support handling and storage of the spent fuel treatment product. Modifications included addition of a special nuclear material monitor, metal detector, Argus access panel, and cameras and motion sensors (evaluated and replaced as necessary).

- Additional modifications and equipment installations to support other potential new work, including a new criticality alarm system to allow handling of containers with greater than 700 grams of uranium mass, which is not required for the LEU sodium disposition product in its storage container, and installation of an upgraded heating, ventilating, and air conditioning system into CPP-651 that includes high-efficiency particulate air filtration.

- Installation of an uninterruptible power supply (UPS) into CPP-1674 
- Improvements to the heating, ventilating, and air conditioning system in CPP-1634.

- Documentation of construction:

- Preparation of as-built drawings for building modifications and equipment installations

- Preparation of system design descriptions for active and passive safety systems related to the DSA

- Identification of essential and master facility drawings

- Close out of the applicable engineering jobs (EJ-197 and EJ-1096).

- Implementation of the safety basis into operating procedures:

- Operating procedures for spent fuel treatment product receipt at CPP-651 and storage in the north vault

- Facility emergency response procedures

- Preventive maintenance procedures for all applicable building modifications and installed equipment.

- Completion of readiness assessments:

- Implementation of management self-assessment for DSA implementation

- Preparation for and completion of a Battelle Energy Alliance, LLC (BEA) management self-assessment

- Preparation for and completion of a BEA readiness assessment

- Preparation for and completion of a DOE readiness assessment that evaluates whether the facility can safely and efficiently initiate nuclear materials storage operations:

- 10 CFR 830-compliant DSA

- Operating procedures

- CPP-651 staffing and training of operators

- Equipment operability.

- Completion and submittal of CD-4 paperwork:

- The federal project director prepared a memo to the acquisition executive that verified key performance parameters and the project completion criteria as described in the MSCP project execution plan

- Completion of PLN-4173, "Material Security and Consolidation Project - Transition to Operations Plan"

- Completion of construction, documented by the partial and final project transfer documents

- Implementation of the upgraded 10 CFR 830-compliant DSA

- Issuance of the final safety evaluation report

- Successful completion of a DOE readiness assessment, including a corrective action plan for all pre-start and post-start findings with a schedule to closure

- Successful completion of system operability for all work scope

- Updated code of record to as-built configuration of the project. 


\subsection{Technical, Cost, and Schedule Baseline Accomplishments}

Table 1. Technical, cost, and schedule baseline accomplishments.

\begin{tabular}{lcccc}
\hline \multicolumn{1}{c}{$\begin{array}{c}\text { Critical } \\
\text { Decision }\end{array}$} & Approval Dates & $\begin{array}{c}\text { Operating Cost } \\
(\$)\end{array}$ & $\begin{array}{c}\text { Capital Cost } \\
(\$)\end{array}$ & Total Cost \\
\hline CD-0 & August 4, 2008 & $\$ 572,999$ & $\$ 0$ & $\$ 572,999$ \\
CD-1 & May 5, 2011 & $\$ 1,641,447$ & & $\$ 1,641,447$ \\
CD-2/3 & September 27, 2011 & $\$ 311,380$ & $\$ 1,132,235$ & $\$ 1,443,615$ \\
CD-4 & January 28, 2013 & $\$ 1,581,014$ & $\$ 10,019,762$ & $\$ 11,600,776$ \\
Total & & $\mathbf{\$ 4 , 1 0 6 , 8 4 0}$ & $\mathbf{\$ 1 1 , 1 5 1 , 9 9 7}$ & $\mathbf{\$ 1 5 , 2 5 8 , 8 3 7}$ \\
\hline
\end{tabular}

\subsection{Significant Changes to the Project Baseline}

Several changes were made to the project baseline in response to customer requests and in response to realized risks.

The original mission need scope was defined at CD-0; however, at CD-1, DOE priorities had changed and the scope was changed to align with the defined needs at the time, which resulted in modifications (described in the scope above) for storage of LEU material in CPP-651.

\subsection{Identified Opportunities for Related New Business or Technical Transfer}

Additional capabilities were installed into the building in an effort to accommodate potential future business opportunities. Also, the DSA was written to include some of the potential opportunities (such as drum storage and re-packaging). However, additional work would be required by a new separate project to complete the necessary facility upgrades and modifications, operating procedures, and readiness assessments.

\subsection{Baseline Change Log}

See Appendix A.

\section{OPEN ITEMS REQUIRED IN ORDER TO COMPLETE THE PROJECT}

In order to complete the project, the contract with CH2M-WG Idaho, LLC (CWI) needed to be closed. Work on the CWI contract has been completed and the associated charge numbers have been closed. However, before the contract may be closed, CWI needs to calculate the final general and administrative adders to their labor rate, which occurs at the end of Fiscal Year 2013. As a result, the CWI contract will remain open until the final labor rate adjustments are made during October 2013.

The final cost will be published after the final CWI contract is closed and will be amended to this report. The cost closing information shows total project costs to date. The adjustment for the CWI final contract costs is anticipated to be insignificant.

There are no other open items required to complete MSCP.

\section{PERMITS, LICENSES, ENVIRONMENTAL DOCUMENTATION, WARRANTIES, AND SERVICE CONTRACTS}

No special permits or licenses are required to construct or operate the facility (such as air quality permits or a permit to construct). An environmental checklist, INL-11-003, "Facility Construction and 
modification in Support of the Material Security and Consolidation Project," was performed for the project's work scope, which documents BEA's environmental compliance to environmental laws, rules, and regulations. The specific work activities evaluated in the environmental checklist include the following:

- Facility infrastructure modifications

- Facility security modifications

- Storage of recovered LEU from sodium-bonded fuel treatment.

\subsection{Permits, Licenses, and Environmental Documentation Generated}

Environmental checklist, INL-11-003, was generated for MSCP.

\subsection{Warranties and Service Contracts Maintained by the Customer/Facility Manager or Owner}

The UPS was purchased with a Construction Field Problem that stated, "An additional four (4) years of factory maintenance service shall be bundled with the initial purchase of the UPS." BEA issued a separate subcontract to capture this commitment. The subcontract number is 133960 , dated September 12 , 2012, through September 12, 2017.

All other materials and construction work are warranted under the standard 1-year construction warranty included in the construction subcontract.

\section{POST-PROJECT COMMITMENTS}

The readiness assessment identified several items that must be completed prior to shipping the LEU to CPP-651. This work was not in the scope of MSCP and a separate project will be required to perform the actual shipping of the material to the building.

The project required the subcontractor to supply factory maintenance support for the UPS in CPP-1674 for a period of 4 years. A subcontract was put in place for this warranty work (subcontract number 133960 between BEA and Nash Electrical, Inc.).

\section{PROJECT FILES}

Project records (such as vendor data, correspondence, technical data, plans, and approvals) have been dispositioned and can be located in the eRecords vault under Project Number 30050.

\section{RISK}

The project encountered several risks during execution. A complete list of the risks encountered and the costs incurred were tracked in the project risk register. The most significant risks are summarized in Table 2 .

Table 2. Risks encountered by the Material Security and Consolidation Project.

\begin{tabular}{lcl}
\multicolumn{1}{c}{ Description of Risk Encountered } & Cost Impact & \multicolumn{1}{c}{ How The Risk Was Handled } \\
\hline $\begin{array}{l}\text { Criticality alarm system supplier } \\
\text { unable to meet project schedule }\end{array}$ & $\$ 66,333$ & $\begin{array}{l}\text { Initial cost to bid with an } \\
\text { accelerated schedule }\end{array}$ \\
$\begin{array}{l}\text { Security door supplier unable to } \\
\text { meet project schedule }\end{array}$ & $\$ 158,246$ & $\begin{array}{l}\text { Supplier paid to accelerate schedule } \\
\text { - overtime and incentive }\end{array}$ \\
$\begin{array}{l}\text { Winning construction } \\
\text { subcontractor bid was less than } \\
\text { original baseline }\end{array}$ & $-\$ 500,000$ & $\begin{array}{l}\text { Under bid was removed from the } \\
\text { project baseline }\end{array}$
\end{tabular}


Table 2. (continued).

\begin{tabular}{|c|c|c|}
\hline Description of Risk Encountered & Cost Impact & How The Risk Was Handled \\
\hline $\begin{array}{l}\text { Additional precision work was } \\
\text { required to complete the security } \\
\text { door }\end{array}$ & $\$ 112,100$ & $\begin{array}{l}\text { Supplier paid to complete } \\
\text { unanticipated precision work }\end{array}$ \\
\hline $\begin{array}{l}\text { UPS for facility failed early during } \\
\text { construction }\end{array}$ & $\$ 183,208$ & $\begin{array}{l}\text { Installation of a new UPS system } \\
\text { was added to the baseline }\end{array}$ \\
\hline $\begin{array}{l}\text { Construction contractor paid to } \\
\text { accelerate completion }\end{array}$ & $\$ 136,721$ & $\begin{array}{l}\text { Construction contractor paid to } \\
\text { accelerate schedule - overtime }\end{array}$ \\
\hline $\begin{array}{l}\text { Cost of shielding for forklift was } \\
\text { not included in the original } \\
\text { estimate }\end{array}$ & $\$ 96,745$ & $\begin{array}{l}\text { Fabrication of the shielding was } \\
\text { added to the baseline }\end{array}$ \\
\hline $\begin{array}{l}\text { Installation of the criticality alarm } \\
\text { system was added to the } \\
\text { construction subcontractor scope in } \\
\text { response to a customer request }\end{array}$ & $\$ 74,371$ & $\begin{array}{l}\text { Cost to install the criticality alarm } \\
\text { system was added to the project } \\
\text { baseline }\end{array}$ \\
\hline $\begin{array}{l}\text { Three additional qualified } \\
\text { operators were identified as } \\
\text { necessary by MFC operations to } \\
\text { support the management } \\
\text { self-assessment and readiness } \\
\text { assessments }\end{array}$ & $\$ 131,427$ & $\begin{array}{l}\text { The cost to train the additional } \\
\text { operators was added to the baseline }\end{array}$ \\
\hline $\begin{array}{l}\text { Design work for Phase } 2 \text { scope was } \\
\text { added per customer request }\end{array}$ & $\$ 138,392$ & $\begin{array}{l}\text { Costs for Phase } 2 \text { design scope was } \\
\text { added to the baseline }\end{array}$ \\
\hline $\begin{array}{l}\text { Project integration for Phase } 2 \\
\text { scope was added per customer } \\
\text { request }\end{array}$ & $\$ 58,957$ & $\begin{array}{l}\text { Costs for Phase } 2 \text { project integration } \\
\text { was added to the baseline }\end{array}$ \\
\hline $\begin{array}{l}\text { The DOE readiness assessment did } \\
\text { not complete in parallel as assumed } \\
\text { in the baseline due to a change in } \\
\text { the DOE Order } 425.1 \mathrm{D} \text {, which did } \\
\text { not allow concurrent reviews }\end{array}$ & $\$ 50,484$ & $\begin{array}{l}\text { The baseline was modified to add a } \\
\text { separate activity for the DOE } \\
\text { readiness assessment }\end{array}$ \\
\hline $\begin{array}{l}\text { Sensor heads for the criticality } \\
\text { alarm system failed during system } \\
\text { operability testing in spite of } \\
\text { passing earlier testing at the } \\
\text { factory; replacement heads had to } \\
\text { be installed into the system }\end{array}$ & $\$ 133,395$ & $\begin{array}{l}\text { The baseline was modified to add } \\
\text { the costs for replacement sensor } \\
\text { heads }\end{array}$ \\
\hline $\begin{array}{l}\text { The system operability test for the } \\
\text { criticality alarm system was } \\
\text { repeated to show operability of the } \\
\text { entire system following installation } \\
\text { of replacement of sensor heads }\end{array}$ & $\$ 25,995$ & $\begin{array}{l}\text { The baseline was modified to add } \\
\text { the costs for re-running the } \\
\text { criticality alarm system sensor } \\
\text { heads }\end{array}$ \\
\hline $\begin{array}{l}\text { Total cost of risks encountered by } \\
\text { MSCP }\end{array}$ & $\$ 866,374$ & \\
\hline
\end{tabular}




\section{POST-PROJECT REVIEW/LESSONS LEARNED}

See Appendix C.

\section{FINAL COST REPORT AND FINANCIAL CLOSEOUT STATUS}

The final cost closing statement is included in Appendix E and final costs to-date for the project are shown in Table 3.

Table 3. Final costs to-date for the Material Security and Consolidation Project.

\begin{tabular}{lcccc}
\hline \multicolumn{1}{c}{ MSCP } & Fund Source & Funding & Actuals & Delta \\
\hline Operating & 101430 & $\$ 4,175,708$ & $\$ 4,106,840$ & $\$ 68,868$ \\
Capital & 920124 & $\$ 11,152,122$ & $\$ 11,151,997$ & $\$ 125$ \\
Total & & $\mathbf{\$ 1 5 , 3 2 7 , 8 3 0}$ & $\mathbf{\$ 1 5 , 2 5 8 , 8 3 7}$ & $\mathbf{\$ 6 8 , 9 9 3}$ \\
\hline
\end{tabular}

Note: These costs are costs to-date at the publication of this report, including funding that was returned to DOE after CD-4. The final costs will be completed after 2 months of accounting cost closing verifications. Also, the final costs for the CWI subcontract as discussed in Section 3 may result in incidental adjustments. If incidental adjustments are needed, this report will be appended accordingly.

\section{CLOSEOUT APPROVALS}

The project is hereby closed. All final work scope and documentation have been completed. The final completion is documented in the executed PLN-4173, which includes the final project transfer and all approvals.

\section{APPENDIXES}

Appendix A, Baseline Change Log

Appendix B, Warranty Information and Service Contracts

Appendix C, Lessons Learned Report

Appendix D, Design Phase Post-Project Review/Lessons Learned Report

Appendix E, Executed Transition to Operations Plan Project No.: 30050 Material Security and Consolidation Project

Appendix F, Cost Closing Statement 


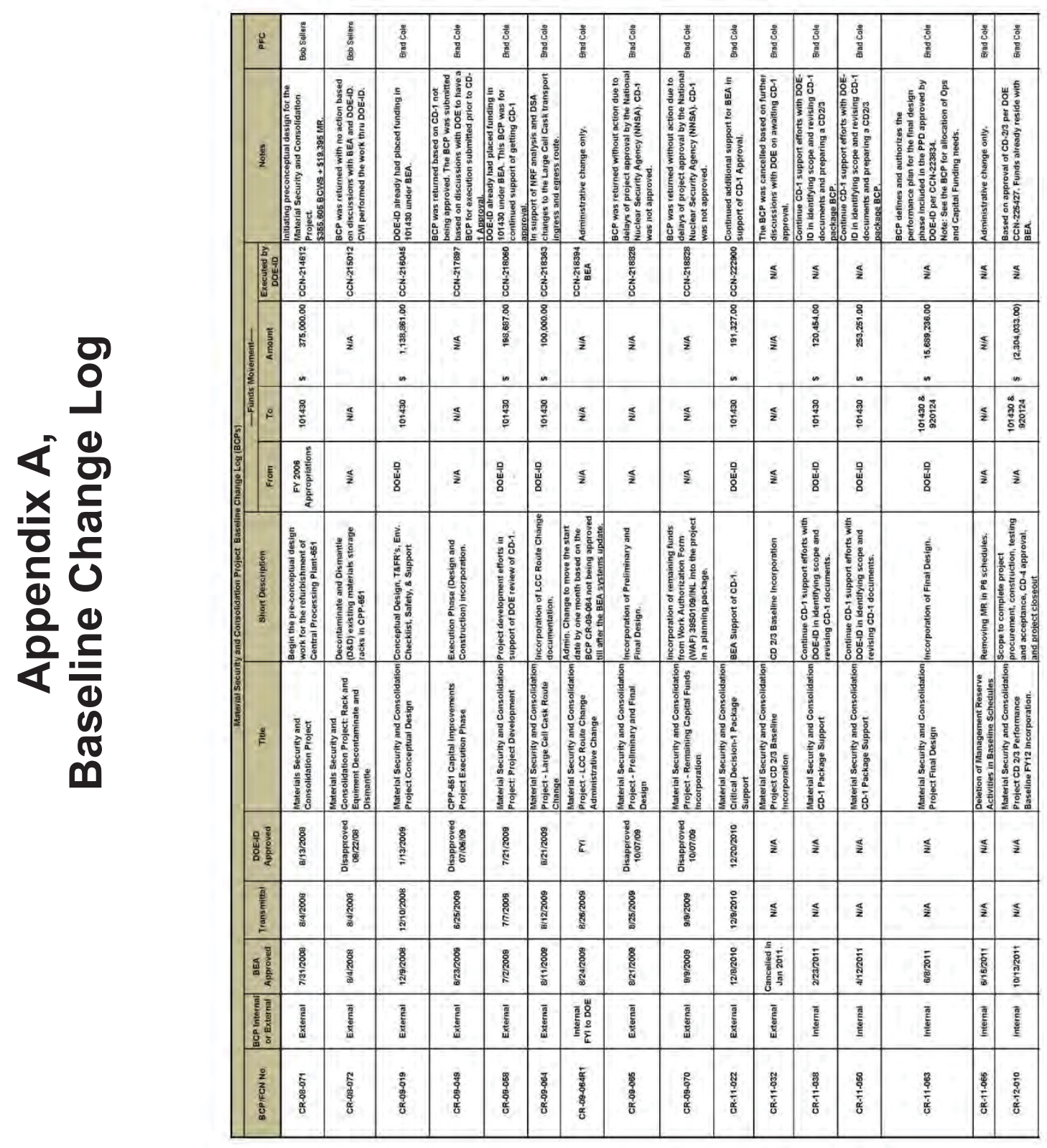




\begin{tabular}{|c|c|c|c|c|c|c|}
\hline$\%$ & 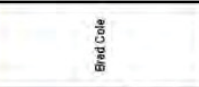 & 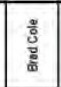 & 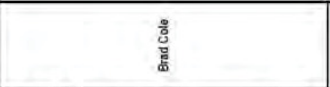 & 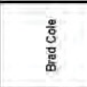 & 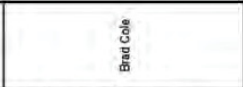 & 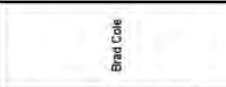 \\
\hline$\frac{2}{\frac{2}{2}}$ & 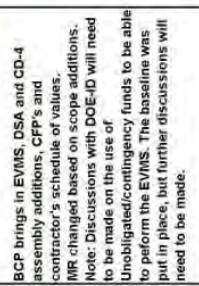 & 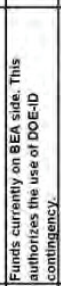 & 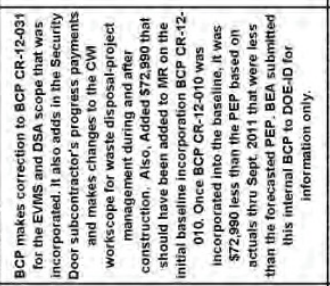 & 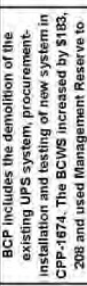 & 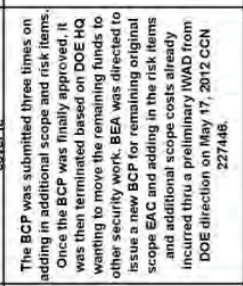 & 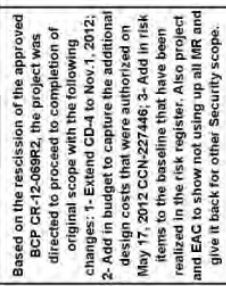 \\
\hline 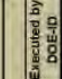 & $\frac{\varsigma}{z}$ & 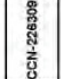 & $\frac{\underline{s}}{2}$ & $\frac{\underline{s}}{\underline{z}}$ & 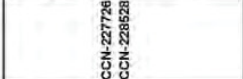 & $\frac{5}{5}$ \\
\hline$\frac{1}{\sqrt{n}}$ & $n$ & 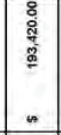 & $\begin{array}{l}8 \\
\frac{8}{80} \\
8 \\
0\end{array}$ & 。 & 。 & 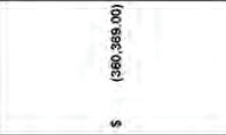 \\
\hline $4:$ & $\frac{\Omega}{2}$ & $\frac{\pi}{8}$ & $\frac{\varsigma}{\Sigma}$ & $\frac{\varrho}{2}$ & $\frac{\widehat{\Lambda}}{2}$ & $\frac{\nwarrow}{z}$ \\
\hline$\frac{5}{2}$ & $\frac{\pi}{2}$ & 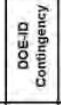 & $\frac{\mathfrak{s}}{\grave{z}}$ & $\frac{\frac{s}{2}}{\frac{1}{2}}$ & $\frac{5}{2}$ & $\frac{\pi}{2}$ \\
\hline$\frac{\delta_{\bar{n}}}{2}$ & 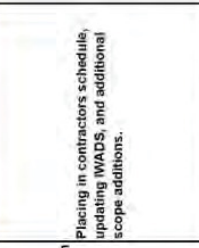 & 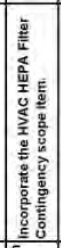 & 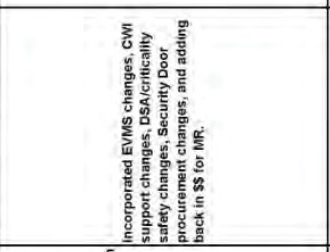 & 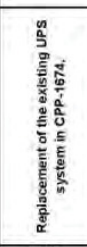 & 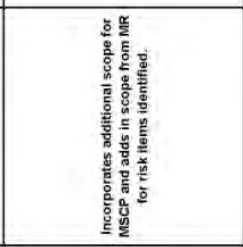 & 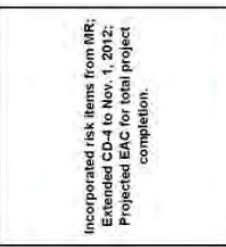 \\
\hline 蛋 & & 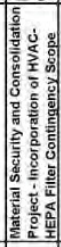 & 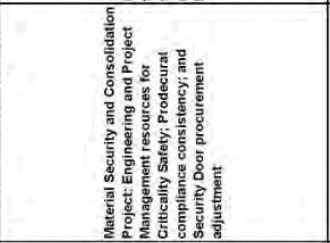 & 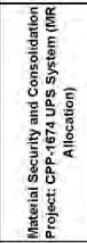 & 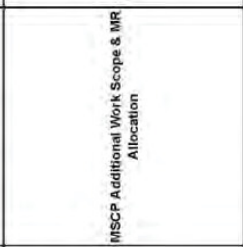 & 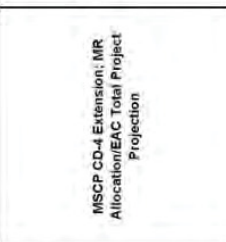 \\
\hline 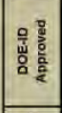 & $\frac{\mathrm{S}}{\mathrm{Z}}$ & 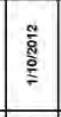 & 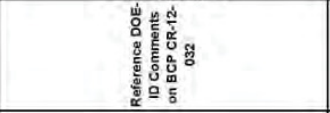 & $\frac{\varsigma}{2}$ & 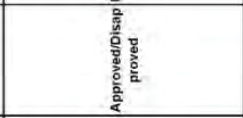 & 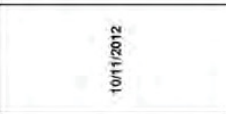 \\
\hline 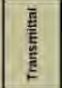 & $\frac{\Omega}{2}$ & 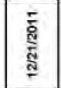 & $\frac{\S}{2}$ & $\frac{\pi}{2}$ & 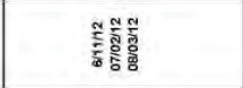 & 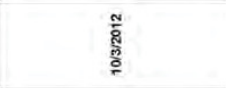 \\
\hline 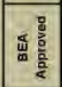 & 言 & 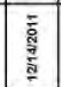 & 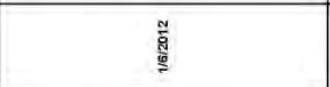 & 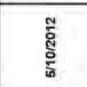 & 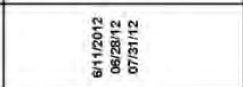 & 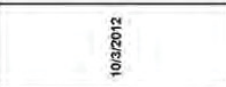 \\
\hline II & $\sqrt{1}$ & \begin{tabular}{|l|l|}
1 \\
\end{tabular} & $\sqrt{1}$ & 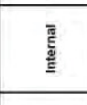 & $\begin{array}{l}\bar{n} \\
\end{array}$ & $\overline{\mathrm{I}}$ \\
\hline 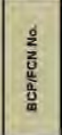 & 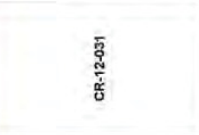 & 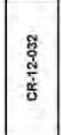 & 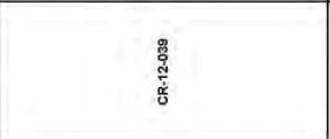 & 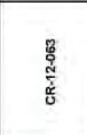 & 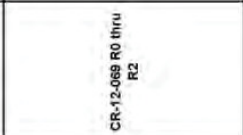 & 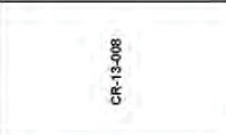 \\
\hline
\end{tabular}




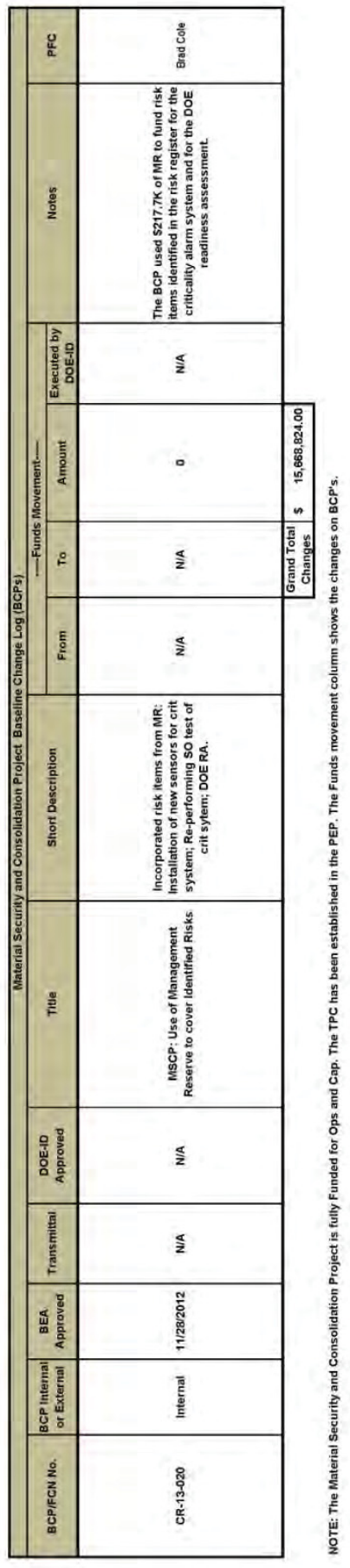

$a$ 


\title{
Appendix B,
}

\section{Warranty Information and Service Contracts}

INI IORM
IDECO-18Y)

osizosiotio

CONTRACT NO. 133960

Nome 1

BATTELLE ENERGY ALLIANCE, LLC (BEA)

2525 I remoni Avetuc. P. O. Bax I625. fdaiso Falls. II) 83415

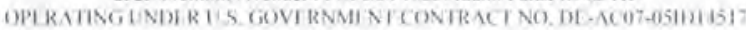

\author{
To: Dash Hectrical. Ine \\ $79 \times 800 \mathrm{~W}$ \\ Black tos (II) $\times 3221$ \\ Hiair Nash Pll: 12081681.5467 \\ Effective Date: $09 / \mid 2 / 2012$ \\ Completion Date: 19122017
}

\section{STATEMENT OF WORK}

1.1. Nash Electricul. Inc. (Subentractor) shall furnish the following services, factory maintenance support for the UPS in CPP-1674 in accordance with the requirements-terms and conditions specified or referenced in this Contract.

2. RESOURCES

2.1. The Subcontractor shall provide all resources, e.g. materials, labor, equipment, facilitics necessary to fulfill the requirements of this Contract. except as otherwise specified

3. APPLICABLE DOCUMENTS the following documents are incorporated into, and become a part of. this Contract:

3.1. INL Site Construction Jurisdictional Procedural Agreement.

3.2. INI. Site Labor Stabilization Agreement

3.3. CFP078RI from Contract 119824 .

3.4. Form 540.37. "Construction Field Problem/Change."

3.5. Site Stabilization Agreement. Appendix A. Wage Rates, dated $0201 / 2013$

3,6. Subcontractor Requirements Manual (Doc. No. 10C-732). Revision 44_dated 12/20/2012. required parts identified as follows

(htips:/inlportal. inl.gov/portal server.pt/community/procurement 346/documents and forms R

3.6.1. PDD-1001 Subcontractor Requirements Program Description

3.6.2. RD-1002 Safeguards and Security Requirements

3.6.3. RD-1003 General Requirements

3.6.4. RD-1004 Motor Vehicle Safety

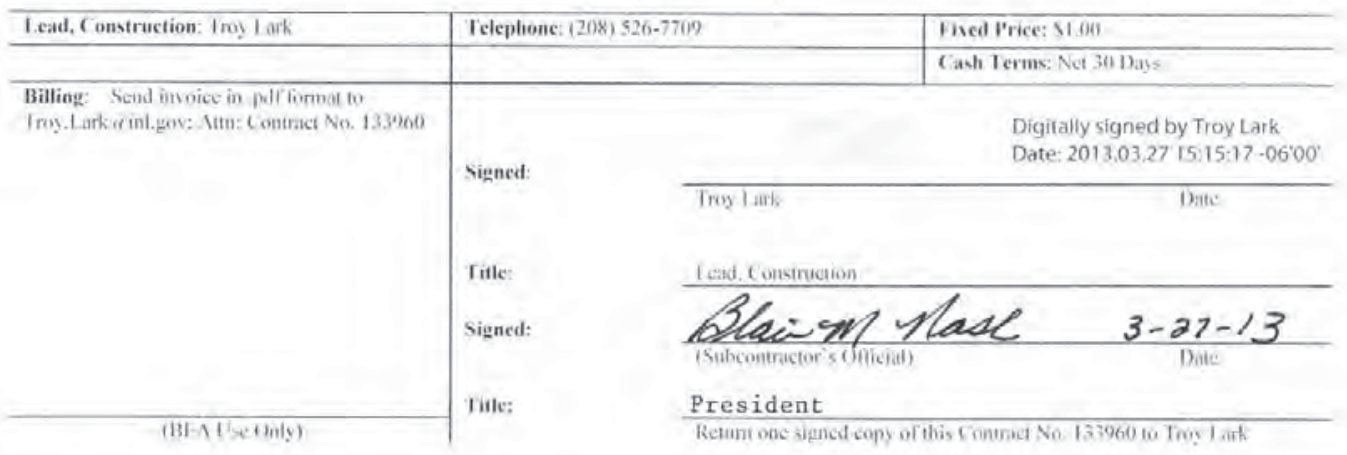


3.6.5. RD-1008 Training and Indoctrination

3.6.6. 2000 Series: Incorporated as applicable to the scope of work

3.6.7. RD-5008 Control of Purchased Items

3.6.8. RD-8000 Environmental Requirements for Subcontractor Equipment and Service

3.7. Form 451.03. "Subcontractor Environmental Requirements Checklist."

3.8. Form PROC-1861. "Occurrence Notification and Reporting by the Supplier."

3.9. DOE F 5484.3, "Individual Accident/Incident Report."

\section{TERMS AND CONDITIONS}

4.1. American Recovery and Reinvestment Act (ARRA). There is potential for work performed under this Contract to be funded by the ARRA. When such occurs, Form PROC-ARRA. General Provisions Supplement for Items/Services Acquired Under the American Recovery and Reinvestment Act, will augment other General Provisions applicable to this Contract.

4.2. General Provisions: The following document is incorporated by reference and hereby forms a part of this action: Form PROC-205. BEA General Provisions for On-Site

Services/Construction Fixed Price/Fixed Rates, dated December 2012. Note: BEA's General Provisions are available at the following Internet address: https://inlportal.inl.gov/portal/server.pt/community/procurement/346/documents and fo rms.

4.3. Subcontractor Requirements Manual: The Subcontractor and all lower-tiers shall perform work in accordance with the Subcontractor Requirements Manual (SRM) to the extent specified in Section 3, APPLICABLE DOCUMENTS. The Lead, Construction shall notify the Subcontractor of changes to the SRM. The Subcontractor shall notify the Lead. Construction within 15 days of the notification if any material impact on cost or schedule results from the SRM change. The notice shall include an assessment of the cost or schedule impact associated with the SRM change. The Lead, Construction shall provide direction to proceed or not proceed with the SRM change. If direction is provided to proceed, the Subcontractor must proceed with the execution of the work as modified by the SRM change and a request for equitable adjustment may be submitted by the Subcontractor consistent with the Changes clause of the General Provisions.

4.4. Certification of Eligibility: Subcontractor, by entering into this Contract, certifies that it is not debarred, or proposed for debarment, by the Federal Government. Disclosure that Subcontractor was debarred. suspended, or proposed for debarment. by the Federal Government on or before the effective date of this Contract shall constitute an additional basis for termination under the Default Article of the General Provisions.

4.5. IRS Forms: Pursuant to U.S. tax law, BEA is required to report certain payments to the Internal Revenue Service (IRS). The Subcontractor agrees to furnish a completed IRS Form W-9, (for U.S. persons). W-8 (for non-U.S. persons) or other applicable IRS form to BEA prior to any request for payment. Forms can be accessed at http:/www.irs,gov/app/picklist/list/formsInstructions.html. (W-9 form can be accessed at: http:/ www.irs.gov/pub/irs-pdf/fw9.pdf?portlet=3) Forms may be submitted electronically to: Vendorinfo $a$ inl.gov or faxed to (208) 526-8240. 
4.6. Sales Tax: Subcontractor's price shall include Idaho sales tax for materials specified under this Contract, if any.

4.7. Tax Reporting: In addition to the Federal, State and Local Tax requirements. contained in the applicable General Provisions. the Subcontractor is reminded of its obligation to comply with tax reporting requirements, including the reporting of assets that may be subject to any personal property or transient personal property tax. Subcontractor should be aware that the geographical boundaries of the INL encompass multiple counties. A map of counties within the INL boundaries is available at

https:/inlportal.inl.gov/portal/server.pt/community/procurement/346/documents_and forms.

4.8. Insurance: During the term of this Contract. Subcontractor shall maintain insurance in accordance with coverage and limits identified in BEA's General Provisions. The insurance certificate shall be endorsed to name "Battelle Energy Alliance, LLC and its successors in interest" and the "U.S. Department of Energy" as additional insured parties.

4.9. Site Stabilization Agreement/Jurisdiction Agreement: These two agreements shall be enforced on this Contract in accordance with agreements set forth between the Construction Trades. DOE. and BEA. The Subcontractor and all lower-tier subcontractors must become signatory to the Site Stabilization Agreement prior to commencement of any on-site construction. During the course of this Contract, at any given period of time, the wage rate (i.e.. Davis Bacon or Site Stabilization) that is higher shall be paid.

4. 10. Worker Safety and Health Program: The scope of this Contract falls under the provisions of 10 C.F.R. Part 851

4.10.1. The Subcontractor shall perform work in accordance with BEA s DOE-approved Worker Safety and Health Program (WSHP), which is implemented by following the Subcontractor Requirements Manual (SRM). The SRM are available for review at: http://inlimages.inl.gov/imageserver/docs/inl/procurement/Subcontractors $\% 20 \mathrm{Req}$ uirements\%20Manual/toc-732.pdf.

4.10.2. The Subcontractor shall ensure that all work performed under this Contract (inclusive of lower-tier subcontractors) is performed in accordance with the Department of Energy's Worker Safety and Health Rule codified at 10 C.F.R. Part 851 . The Subcontractor is subject to all applicable procedures for investigating violations, enforcing compliance with requirements, and assessing civil penalties or fee reductions for violations under the DOE's Worker Safety and Health Rule.

4.10.3. The Subcontractor shall ensure that its employees and those of any lower-tier subcontractor are medically qualified to perform work as required by 10 C.F.R. Part 851 . These Occupational Medicine requirements are further defined in the Contract Requirements Manual, RD-1001. The Subcontractor will have the option to utilize BEA's Occupational Medical Program (OMP) or elect to utilize its own OMP to satisfy the Occupational Medicine requirements. BEA will offer a majority of OMP services to the Subcontractor on a graded approach as defined in RD-1001; however. notwithstanding that BEA may provide the OMP services, the Subcontractor shall be responsible to ensure compliance with all requirements included in 10 C.F.R. Part 85I, including all requirements of Section 8. Occupational Medicine, of Appendix A to the Regulation. Medical certification and surveillance programs are the sole responsibility of the Subcontractor as required by 29 C.F.R. Parts 1910 and 1926. There is no change 
to this requirement: however, if a Subcontractor employee has been to an Occupational Medical provider for one of these certification or surveillance programs and has received a medical evaluation that includes fitness for duty (such as respirator users) this evaluation may satisfy the pre-medical evaluation requirement as outlined in 10 C.F.R. Part 851 and not need duplication. The Subcontractor shall be responsible for maintaining any medical records in accordance with all applicable regulations and as defined in RD-1001.

4.10.4. The Subcontractor assumes full responsibility and shall indemnify, hold harmless, and defend BEA, its directors, officers and employees from any civil liability under 10 C.F.R. Part 851 or related regulations or statutes, arising as a result of work performance by the Subcontractor, its lower-tier subcontractors, suppliers, agents, employees and their officers or directors. The Subcontractor's obligation to indemnify and hold harmless shall expressly include attorney fees and other reasonable costs for defending any action or proceeding instituted under 10 C.F.R. Part 851 or related regulations or statutes.

4.10.5. BEA may inspect the Subcontractor's operation and records, from time to time, for compliance with worker safety and health requirements contained in this Contract. BEA will provide written direction to the Subcontractor relative to necessary corrections commensurate with deficiencies found; however. BEA's failure to find or to provide written direction regarding a deficiency does not relieve Subcontractor of any obligation under the Worker Safety and Health Rule, or otherwise. The Subcontractor shall make these corrections at no additional expense to BEA.

4.10.6. Prior to the performance of onsite work, each Subcontractor employee shall complete Form 340.33, "Comprehensive Medical Questionnaire," and return completed form via U.S. Mail in a sealed envelope labeled - "To Be Opened By Addressee Only" to: Idaho National Laboratory. Attn: Occupational Medicine, P.O. Box 1625, Idaho Falls, ID 83415-3125; or hand deliver Form 340.33 to the Medical Department in the Willow Creek Building, 1955 Fremont Ave., Idaho Falls, ID 83415. (Please ask at the from desk to be escorted to the Medical Department. The Medical Department will have blank forms available for completion). If difficulty is encountered or delays are expected, please address any questions or concerns to the Subcontracted Work Office (SWO) at (208) 526-4667.

4,II. Disposition of Contaminated Construction Equipment. Tools and Material: Work performed under this Contract has the potential for exposure in a Radiological Buffer Area (RBA). For identification of hazards associated with this work, refer to the applicable section(s) of the Contract Special Conditions document.

4.11.1. Subcontractor shall use its own equipment in performing the work. All tools, vehicles, equipment and material will be inspected for radioactive contamination by BEA prior to removal from the RBA.

4.11.2. Should Subcontractor's tools, materials, or equipment become contaminated, they will be decontaminated by BEA prior to removal from the RBA. Subcontractor shall allow a minimum ten (10) work days for BEA to accomplish decontamination.

4.11.3. If decontamination proves impracticable or impossible. the tools, material, or equipment in question will be retained by BEA and a confiscation report will be completed. An equitable adjustment, with an allowance for overhead but no profit. will be negotiated 
with Subcontractor, or at BEA's option, the tools will be replaced by BEA. The tool/equipment reimbursement schedule will be applied as follows:

4.11.3.1. Personal Clothing at $100 \%$ of replacement cost.

4.11.3.2. Tools Equipment valued less than $\$ 1,000.00$ at $95 \%$ of replacement cost.

4.11.3.3. Tools/Equipment valued at $\$ 1,000.00$ or more. if less than one year old or at top of depreciation schedule, at $75 \%$ of replacement cost or if at the bottom of, or off. the depreciation schedule. at $50 \%$ of replacement.

4.12. Subcontractor Apprenticeship Certifications: Prior to using apprentices under this Contract, the Subcontractor shall submit a Davis-Bacon Certification evidencing that the apprentice program and apprentice(s) employed under the Contract are registered with the Office of Apprenticeship, U.S. Department of Labor. The Davis-Bacon Certification shall be obtained from the Office of Apprenticeship. Subcontractor requests for the Certification may be sent to: Employment and Training Administration. Office of Apprenticeship. Idaho State Office. 1150 North Curtis Road. \#204, Boise. ID 83706, Attn: John Cantrell (facsimile number 208321-2978).

4.13. Security Requirements:

4.13.1. Subcontractor personnel performing on-site services under this Contract shall have a Building Access Only (BAO) clearance. Unless otherwise approved by BEA in writing. Subcontractor personnel (including lower-tier Subcontractors) must be U. S. citizens to gain admittance to the site. Subcontractor shall request the number of security packets. from the BEA Lead, Construction, needed for this Contract.

4.13.2. Subcontractor's failure to obtain sufficient BAO clearances to have a crew of sufficient size BAO-cleared in time to meet completion/delivery requirements may result in termination of the Contract for default.

4.13.3. The Subcontractor must obtain a sufficient number of BAO clearances to provide a margin for illnesses, personnel terminations and individuals whose clearances require extended processing time.

4.14. Construction Change Control System: Subcontractor shall request clarification of. or request relief or deviation from. a requirement(s) of this Contract, including BEA-approved. Subcontractor-originated documents, otherwise herein designated as "Vendor Data" or "Supplier Data". Approval to be relieved or to deviate from a requirement(s) of this Contract must be obtained by the Subcontractor prior to start of the affected work. Repair or rework of nonconforming goods or reperformance of on-site services that involve BEA coordination or support is defined as a deviation from the requirements and must be approved, via Change Notice o: Change Order, prior to rework, repair or reperformance. All clarifications of, or deviations from, a requirement(5) of this Contract shall be incorporated into the affected contractual document(s), using red indelible ink. The only acceptable method of incorporating a clarification/deviation into a contractual document is by: 1) drawing a single red line through the affected requirement(s) on the affected document(s);2) "clouding," or otherwise highlighting, the clarified/deviated requirement: 3 ) initialing and dating (by the individual incorporating the clarification deviation); and 4) referencing the request that authorized the clarification/deviation. 
4. 15. Idaho National Laboratory Environmental Policy: Subcontractor shall adhere to the INI. Envirommental Policy found at hitp:/www.inl.gov/environmentalpolicy/.

4.16. Lower-tier Subcontractors: Subcontractor shall not subcontract performance of any porticut of the work being performed at BEA without the advanced written approval of BEA. (excluding material deliveries). Lower-tier subcontracts and purchase orders must include provisions to secure all rights and remedies of BEA and the Government provided under this Contract. and must impose upon the lower-tier subcontractor all of the general duties and obligations required to fulfill this Contract. Subcontractor is responsible for the performance and oversight of all lower-tier subcontractors.

4.17. Suspect/Counterfeit Items ( $\mathrm{S} / \mathrm{Cl}$ ): The Subcontractor shall verify that items do not exhibit any suspect or counterfeit characteristics as defined by RD-5008 Appendix A. General Indicators for Identifying Suspect/Counterfeit Items and RD-5008 Appendix B. Commodity Suspect Indicators List. Subcontractor personnel shall be trained on the identification of suspect/counterfeit characteristics prior to performing this activity. The Subcontractor shail verify that all fasteners $\left(0.25^{-.}\right.$nominal and above) including those components, equipment. and or assemblies do not exhibit headmarks listed in RD-5008 Appendix E. DOF. Headmark list. RD-5008 Appendix D. Fasteners and RD-5008 Appendix F. Refurbished Molded Case Circuit Breakers, provide additional instructions for commodities with suspect or counterfeit history.

\subsection{Toxic Chemical Release Inventory Reporting:}

4.18.1. As used in this clause, "Toxic Chemical Release Inventory Reporting," the Emergency Planning and Community Right to Know Act of 1986 (42 U.S.C. $11001-11050$ ) (EPCRA) and the Pollution Prevention Act of 1990 (42 U.S.C. 13101-13109)(PPA). established programs to protect public health and the environment. Under these Acts. certain businesses are required to submit reports each year on the amounts of toxic chemicals their facilities release into the environment.

4.18.2. The Subcontractor shall comply with its certification entitled, "Certification of Filing Toxic Chemical Release Inventory Reporting Form (Form R)." which was part of its proposal and is expressly incorporated herein by reference.

4.18.3. The Subcontractor shall insert in all first tier subcontracts a clause substantially the same as this clause (without this paragraph).

4.18.4. Remedies. If the Subcontractor inaccurately, incompletely or falsely certified as to a facility's compliance with the reporting requirements of EPCRA section 313 and PPA section 6607. or if any of the Subcontractor's facilities has deliberately not filed a Toxic Chemical Release Form, or deliberately not submitted complete information. BE $\wedge$ may terminate the Subcontract or take other appropriate action.

4.19. Recovered Materials: This Contract includes the acquisition of environmentally-preferable products that are, or can be, made with recovered (recycled) materials. In accordance with Executive Order 13101. entitled "Greening the Government Through Waste Prevention. Recycling, and Federal Acquisition," BEA is committed to purchase items that contain recycled materials, as designated by the Environmental Protection Agency in the Comprehensive Guidelines (CPG). By acceptance of this Contract Subcontractor certifies that 
the percentage of recovered materials and/or post consumer waste content for EPA designated items is at least the amount required by the applicable purchase description/specification. The Subcontractor shall submit a fully executed Form 540.15, Recovered Materials Report for Construction Services, in accordance with the Reports and Data paragraph.

4.20. E-Verify: Subcontractor shall comply with FAR 52.222-54, Employment Eligibility Verification (January 2009). Information on registration for and use of the E-Verify program

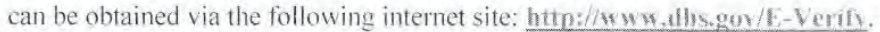

4.21. DOE O 442.2. Differing Professional Opinions for Technical Issues Involving Environment. Safety and Health: Regardless of the performer of the work, the Subcontractor is responsible for complying with the requirements of this clause. The Subcontractor is responsible for flowing down the requirements of this clause to subcontractors at any tier to the extent necessary to ensure the Subcontractor's compliance with the requirements. The Subcontractor must:

4.21.1. Ensure that all personnnel and subcontractor personnel are notified quarterly that they have the right to report environment, safety, and health technical concerns that have not been resolved through routine work processes through the Department of Energy Differing Professional Opinion (DPO) process (the DOE DPO process can be found a http://www.hss.doe.gov/nuclearsafety/qa/dpo.html). The notification must provide points of contact (name, phone number and email addresses of DPO Managers) as listed on the DOE DPO web page, as well as the DOE DPO web page address.

4.21.2. Protect Subcontractor personnel from reprisal or retaliation for reporting a DPO.

4.21.3. Provide Subcontractor employees reasonable time and resources to use the DPO Process.

4.21.4. Assist DOE as requested in the resolution of DPOS.

4.21.5. Report to the DOE when requested on the status of assigned implementation actions resulting from the DPO resolution and on the closure of these implementation actions.

\section{ORDER OF PRECEDENCE}

5.1. In the event of any inconsistency between provisions of this Contract. the inconsistency shall be resolved by giving precedence as follows:

5.1.1. Contract Change documents, if any

5.1.2. Contract

5.1.3. General Provisions

5.I.4. Other provisions of this Contract, whether incorporated by reference or otherwise.

5.2. Subcontractor shall notify BEA prior to performing work based on resolution of an inconsistency by the order of precedence set forth herein.

\section{PRICE}

6.I. The firm-fixed price of this Contract is $\$ 1.00$.

6.2. Mark-up Rates: The following markup rates shall be used for price adjustment under the "Changes" and "Differing Site Conditions" articles of the General Provisions: 
6.2.1. Overhead: This rate shall compensate the performing subcontractor (i.e., could be prime subcontractor or a lower tier subcontractor at any level) for indirect costs allocable to the price adjustment for a change. The amount allowed for overhead shall include. but is not limited to : vehicles, operating costs of vehicles, maintenance of vehicles: office buildings, furniture, office equipment, storm damage and repairs, safety supplies. welder testing, janitorial labor and supplies, cleanup labor, survey signs and barricades: insurance. taxes and legal support: home office general and administrative (G\&A); home office and on-site project management and supervision, including project managers, superintendents. engineers. QA/QC, purchasing, estimating, secretaries, and clerks, small tools and other consumables. The maximum allowable rate is $15 \%$.

6.2.2. Handling: This rate shall provide the only compensation to the supervising subcontractor (any level) for costs/profit incurred in managing the performing subcontractor. The maximum allowable rate is $5 \%$.

6.2.3. Profit: The maximum profit rate(s) for work beyond the initial scope of work shall be allowed in accordance with the following: $10 \%$ if priced prior to starting any work: $7 \%$ if priced during performance of work; and $3^{\circ}$ if priced after work is complete. The basis for profit calculations may be one or more of the following: the Subcontractor price proposal: the Contractor's independent cost estimate; or the negotiated estimated cost. in no event may the final negotiated profit amount be calculated solely as a profit rate applied to actual costs.

6.2.4. Equipment: Hourly rates for Subcontractor-owned equipment shall be at Bluebook Equipment Rental Rates based on applicable monthly, weekly or daily rental rate. All other equipment shall be in accordance with fair market value.

6.2.5. Training Costs: Project specific training costs will be reimbursed as identified on Form 540.37, Construction Field Problem/Change (CFP), and approved by the Construction Field Representative (CFR). Compensable project specific training will be listed in Special Conditions. Mark-up rates do not apply to training cost reimbursements.

6.2.6. Supervision: A reasonable differential from Site Stabilization Agreement (SSA) journeyman rates will be allowed. Supervision costs shall only apply if: 1) the change affects the critical path of the project; and 2) supervision is a direct cost to the project, in accordance with FAR 31.202.

6.2.7. Forward Pricing: The labor and equipment rental rates identified on PROC-1837. Forward Pricing, will be the maximum allowable rates for Subcontractor and lower-tier subcontractors for any change order work submitted under this Contract.

6.2.8. Labor: The minimum allowable rate shall be the current Appendix A rate for the Site Stabilization Agreement (SSA).

6.3. Invoicing:

6.3.1. Submittal of an invoice constitutes Subcontractor's certification that services have been provided, and invoiced amounts are in accordance with the Contract provisions.

6.3.2. Unless otherwise authorized in the Contract, invoices may not be submitted more than once per calendar month.

6.3.3. Invoices shall indicate the cumulative amount invoiced to date. 
6.3.4. Invoices shall be submitted electronically in .pdf format to Troy.Lark at inl.gov.

6.3.5. Subcontractor shall separately identify services performed and billable under this Contract.

6.3.6. Subcontractor shall submit monthly invoices utilizing form PROC-2123, Progress Invoice Request for Construction Subcontracts.

\section{COMPLETION DATE}

7.1. This Contract shall be in effect through 09/12/2017.

\section{REPORTS AND DATA REQUIREMENTS}

8.1. Subcontractor Administrative Submittal Requirements:

\begin{tabular}{|l|l|l|}
\hline \multicolumn{1}{|c|}{ Submittal. } & $\begin{array}{c}\text { When required } \\
\text { (Calendar } \\
\text { Days) }\end{array}$ & \multicolumn{1}{|c|}{ Submit to } \\
\hline Certificate of Insurance & 7 prior to work & SA \\
\hline Recovered Materials Report. form 540.15 & $\begin{array}{l}\text { At completion } \\
\text { of work }\end{array}$ & SA \\
\hline CFP/C.Form 540.37 & $\begin{array}{l}3 \text { diays afier } \\
\text { receipt of } \\
\text { CFP/C if } \\
\text { applicable }\end{array}$ & SA and CTR \\
\hline
\end{tabular}

\section{ADMINISTRATION}

9.1. Subcontractor Administration: The Subcontractor's responsibilities shall be administered by Blair Nash. Subcontractor agrees that Blair Nash will have overall technical direction of the work to be performed by Subcontractor and shall be available at all reasonable times in connection therewith.

9.2. Lower-Tiers: The following lower-tier subcontractor(s) have been authorized by BEA for performance of onsite work under this Contract:

Company Name

Eaton Powerware

9.2.1. These lower-tier subcontractors shall work under the direction of the Subcontractor. Subcontractor shall notify BEA's Subcontract Administrator of any substitution or addition(s) to this authorized list of lower-tier subcontractors at least three (3) days prior to the lower-tier subcontractor's anticipated mobilization onsite. All lower-tier subcontractors must be presented to and authorized, via a written amendment to this Contract. before they will be allowed to work onsite under this Contract. BEA reserves the right to reject any proposed lower-tier subcontractor that cannot demonstrate it has the necessary equipment, organization and expertise to perform the required work. If requested, a proposed lower-tier subcontractor shall furnish references and a list of similar work that it has satisfactorily completed. Subcontractor is fully responsible to 


\begin{abstract}
BEA for the acts and omissions of its lower-tier subcontractors and of all persons either directly or indirectly employed by them just as Subcontractor is responsible for the acls and onissions of persons directly or indirectly employed by it under the Contract. Subcontractor shall examine all lower-tier submittals, such as change price proposals. vendor data submittals or claims, for accuracy and validity prior to submission to BEA. Nothing contained in the Contract shall be construed as creating a contractual relationship between any lower-tier subcontractor and BEA. nor as relieving Subcontractor of its obligations to BEA under the Contract. Subcontractor hereby certifies that all mandatory flow down requirements identified in this Contract (including all applicable documents) have been properly flowed down to the lower-tier subeontractors authorized under this Contract.
\end{abstract}

9.3. Administrative and Legal Jurisdiction. Unless the Subcontractor is otherwise notified in writing. BEA's responsibilities under this action shall be administered by Troy Lark, Lead. Construction, or another authorized Subcontract Administrator named herein or Procurement Manager.

9.4. BEA Work Hours: Unless otherwise stated, authorized work hours for Subcontractors and lower-tiers are: Site: Monday through Thursday, 7:00 am to 5:30 pm; Subcontractor and lower-tiers shall not perform work at the jobsite during other than these hours unless subcontractor has given prior written notification to BEA at least 48 hours in advance and has received approval from the CFR. A request for work during off-normal work hours shall include the type of work to be performed, location of work, date and hours of work and description of any heavy equipment to be used,

\title{
9.5. Technical Representative:
}

9.5.1. The Construction Field Representative (CFR) assigned to this Contract is Lex Strain at (208) 533-4702. BEA's CFR is responsible for technical direction and oversight of the work, during the period of performance. The CFR is solely and exclusively authorized to provide day-to-day technical direction and support in connection with the subcontracted work. Technical direction by the CFR includes, but is not limited to: redirecting the contract effort, shifting work emphasis between locations and/or tasks, responding to Subcontractor inquiries/issues, and providing additional information/detail as may be required; providing documented information concerning scope change or clarification: and providing compliance oversight and interpretation of the Subcontract Requirements Manual.

9.5.2. BEA's CFR has authority to negotiate changes identified on Construction Field Problem/Change (CFP) forms at diftering dollar amounts, but not to exceed $\$ 10,000.00$. The changes identified on the CFP form can only be authorized by the Subcontract Administrator identified in the Contract. Authorized changes will be formally incorporated into the Contract via an amendment.

9.6. Notices: Any notice provided for this action shall be considered as having been given: To BEA, if mailed electronically via e-mail ("Troy.Lark@inl.gov") or fax. or if delivered personally to Troy Lark, or if mailed by U. S. Mail addressed to Troy Lark, Battelle Energy Alliance LLC, 2525 Fremont Avenue, P. O. Box 1625, Idaho Falls, ID 83415: or to the Subcontractor, if delivered personally to its duly authorized representative at the site of work. 
Contract No. 133960

Page 11 of 11

or if mailed electronically via e-mail or fax, or by U. S. Mail addressed to the Subcontractor at 79 S $800 \mathrm{~W}$, Blackfoot, ID 83221. 


\section{Appendix C, Post Project Review/Lessons Learned Report}

This report documents the areas of discussion from the post-project review and also documents lessons learned realized during the post-project review. Therefore, not all discussion represents lessons learned, but is a review of the project execution. The post-project review included the integrated project team.

\section{Mission and Overall Assessment}

The mission of the project was successfully completed and the project team has been commended for their effort and performance. INL now has a renovated, robust facility for storage of nuclear material. This renovated facility provides future capabilities with a new criticality and detection alarm system and a high-efficiency particulate air-filtered heating, ventilating, and air conditioning system. The project mission was successfully completed under budget.

\section{Safety}

Throughout the project life-cycle, work was constructed safely, in spite of challenging/complicated scope in a relatively tight space and working to a very aggressive schedule. This safety record is attributable to the teamwork and communication between all team members, including the construction contractor, BEA construction management, and BEA construction safety. Communication regarding safety from all team members was definitely one of the major contributing factors to the project's success and a positive lesson learned.

The construction team recognized where and when additional attention to safety was needed and voluntarily conducted a safety pause, led by Clayne Hanson of C\&H Construction. This safety pause was conducted voluntarily and concurrently with the Materials and Fuels Complex shutdown that occurred during 2012. During this safety pause, all remaining work scope was reviewed, all job safety analyses were reviewed, and training was verified. This voluntary project team action displays one of BEA's core values: "actively caring for my own and others safety." This core value was flowed down and accepted by all project participants.

The positive lessons learned from this action is to recognize that following the safety pause, the project restarted and all work was accomplished without incident through completion. Projects should not hesitate to stop work and review safety conditions, work processes, or work conditions whenever the team recognizes the need.

\section{Team Work and Communication}

The cohesive project team facilitated communications by keeping team members informed of project progress and issues that needed attention. Teamwork and active communication were essential elements to successful completion of the project. All INL and subcontractor organizations worked together to support a common goal and share in the success of the project. The project team worked diligently to coordinate interface details between all organizations, including the construction subcontractors, specialty fabricators, BEA, and CWI through regular project meetings and formal and informal direct communication.

The project included adequate budget in the baseline to support essential team members through all phases of the project and through completion. As a positive lessons learned, projects should include adequate budget for essential work discipline support during construction, because the support will be needed. If adequate budget for support is not in the baseline, the project will risk going over budget during execution and missing schedule milestones. 
The payoff for ensuring support during construction includes many benefits such as timely resolution of field questions and changes with no schedule delays; quick turnaround of vendor data; and daily, active participation in field activities helped ensure accuracy of the work.

\section{Quality}

For equipment purchased by both BEA and the subcontractor, BEA witnessed factory acceptance tests of specialty equipment by the fabricator prior to shipping. These tests were witnessed by quality, engineering, and operations. Approving the fabrication and testing prior to shipment helped shorten the time required to perform final system operability testing and accept the various equipment systems once they were installed onsite.

This helped ensure that the supplier was in full compliance with the INL and industry quality standards. This support was essential to completing the procurements successfully. In order to ensure the products were fabricated in compliance with the INL quality plan, the quality engineers made trips to the suppliers to first assess their quality plans, second to monitor fabrication, and third witness the final factory system operability testing and release the products for shipping.

As a positive lessons learned, quality should actively participate with the fabricator to ensure compliance prior to and during fabrication, during testing, and should approve the release for shipping. Once equipment has been delivered onsite, rework is expensive; therefore, the benefit to the project is to minimize rework. This approach saves costs and, especially, schedule. If equipment is delivered without being tested first, it may need to be returned to the factory for rework, causing excessive delays to the project schedule.

\section{Construction Procurement Methods and Management}

The project was procured using a pre-bid/pre-qualification process prior to the start of the actual bid process. This helped ensure that the bidders were well versed on the project scope and unique features of the project and the overall laboratory mission and goals for the project. This led the construction subcontractor to select the subtier contractors that they felt were best suited for the project. The general contractor also had the information needed to select familiar subtier contractors based on their working experience, type of work, and their capabilities, even though they may not have been the low bidder.

1. This resulted in a good, hand-picked construction team. The general contractor and the subtier subcontractors all concluded at the end of the project that using quality subcontractors that they were familiar with and accustomed to working with made the project go smoother and all aspects run easier with better coordination and change management.

2. The interview process during procurement/competitive bidding provided a more thorough evaluation of the subcontractor teams. In this case, the best value method was better than basing the selection solely on the lowest bid.

3. The construction subcontractor had interest in doing a good job and in developing future business.

BEA procurement endeavored to process and pay invoices in a timely manner. This practice ensured the best price from subcontractors because they could count on the proper cash flow to support the project work. Bids are naturally higher if the subcontractor believes they are going to need to carry the expense of the project while they wait for payment.

As a positive lessons learned, the project team should be willing to investigate the best procurement method for the particular scope. An open bid may be appropriate in most cases; however, in the case of MSCP, a pre-qualified bid list helped ensure that the project team could gain assurance prior to the bid that the potential subcontractors were qualified for the work, understood the risks, and were prepared to execute the work to meet the project schedule. 


\section{Earned Value Management System}

The project was managed in compliance with Earned Value Management System principles, passing an audit from the DOE Headquarters Office of Engineering and Construction Management for INL's Earned Value Management System certification. Integration of the time schedule, schedule of values, tracking and reporting, and invoicing between BEA and the subcontractor helped keep the project tracking up-to-date and facilitated accurate billings with no disputes or uncertainties.

\section{Risk Management}

- The risk management plan was prepared in conjunction with CD-2/3 approval. The formal risk management plan was utilized throughout the project and proved beneficial in several aspects.

- The plan was used to establish the dollar level for management reserve.

- The risk management plan was reviewed monthly and utilized to identify the cost impacts of risks as they occurred.

- The use of management reserve resulted from realized risks that had been anticipated in the risk management plan. The use of management reserve was then documented with baseline change proposals.

\section{Documented Safety Analysis}

\section{Safety Basis Development}

1. The schedule was aggressive and especially affected safety basis development. Assigning an adequate number of safety analyst resources to the effort early on was crucial to schedule success.

2. Safety analyst involvement in design development and review aided the safety basis development effort by ensuring that the individuals working on the safety basis were up-to-date on the project scope and design. This helped to ensure that the safety basis matched the final design without undue comments or changes during review.

3. Frequent team meetings with safety basis reviewers/approvers minimized issues at the end of the process.

4. Frequent meetings with DOE personnel during comment resolution expedited DOE approval of the safety basis. The willingness of all parties to engage early in the process expedited reviews and approvals.

5. Inclusion of nuclear safety in design facilitated preparation of the safety basis documents and helped the project perform the work as would be done if the project would have been required to meet DOE-STD-1189.

\section{Turnover}

Turnover was accomplished with the use of a turnover and acceptance plan. This plan helped the project team plan for the actions that needed to take place to complete and close out the construction subcontract work.

The turnover took place in phases; as work was completed, the punch list walk down was conducted. Punch list execution was continuously managed and pushed to completion. Project turnovers were well documented and the punch list was completed. Once all punch lists were completed, a final transfer document was prepared.

After turnover from construction, operations performed all remaining final system operability testing, ensuring confidence in the performance of the facility and systems. 
The system engineer, shift supervisor, staff, and nuclear facility manager ensured all maintenance work orders and maintenance vendor data documents were in place. The project hired a dedicated work planner to support preparation of the required work orders.

\section{Startup/Readiness Assessment}

Following construction's substantial completion, the project was verified through the following three actions:

1. A management self-assessment to verify implementation of the DSA was completed.

2. A contractor readiness assessment was conducted that reviewed every aspect of project execution and preparations to operate the facility.

3. A DOE readiness assessment was conducted, which again reviewed every aspect of project execution and verified complete readiness to operate the facility, with the exceptions of the items that were not included in the project baseline.

Use of the management self-assessment and readiness assessments to verify readiness ensured that all aspects of the project were complete. The teams reviewed the documentation for construction completion, red lines and as-built drawings, system operability test results, operating procedures, training and qualifications, periodic maintenance work orders, and in-facility operations.

\section{DOE Readiness Assessment Findings and Lessons Learned}

The following items were identified as part of the readiness review process to be included in the project lessons learned. The responses were entered into the INL Lessons Learned system under the identifier 2013-1127:

\section{CAS.2-PST-2 - Preparation for readiness reviews governed by DOE Order 425.1D requires improvement.}

Corrective Actions

- Develop and issue a lessons learned on the INL lessons learned system. The lessons learned will cover the following:

- The need for projects and operations that are subject to readiness review activities to ensure all applicable core requirements from DOE Order 425.1D are addressed as part of the project planning and execution.

- The need for readiness assessment/operational readiness review readiness-to-proceed declarations to include a corrective action plan and schedule for open items on the manageable list.

Objective evidence - Submitted lessons learned

Performer - Lannie Workman

Due date - 4/29/13

2. CAS.2-OBS-1 - The contractor readiness assessment did not interview any radiological engineers even though the radiological engineers were intimately involved with generation of the project ALARA Review, radiation work permits, and operating procedures.

The following lessons learned were developed to answer these findings:

\section{Lessons Learned for CAS.2-PST-2:}

- The DOE readiness assessment identified a weakness in project/facility planning for readiness review preparations in accordance DOE Order 425.1D, "Verification of Readiness to Startup or Restart Nuclear Facilities." Core Requirement 10 from DOE Order 425.1D 
requires that "an emergency management drill and exercise program have been established and implemented." However, emergency management preparations were included in a future related project and not MSCP. As a lessons learned, the scope of a project subject to readiness review needs to cover all applicable core requirements from DOE Order 425.1D.

- Emergency management preparations were identified as an open (incomplete) item at the start of the contractor readiness assessment. However, DOE Order 425.1D requires that "the prestart issues must have a well-defined schedule for closure to allow the readiness assessment team to review the closure process." A schedule was not provided at the start of the contractor readiness assessment. As a lessons learned, open items at the start of the readiness assessment need a schedule for closure to allow the readiness assessment team to properly evaluate the core requirement.

\section{Lessons Learned for CAS.2-OBS-1:}

- The DOE readiness assessment identified weaknesses in the level of knowledge of select personnel, including radiological engineers. It was noted as an observation that the contractor readiness assessment did not include interviews of the radiological engineers even though they performed key functions with ALARA reviews, radiation work permits, and operating procedures. As a lessons learned, the depth and breadth of the contractor readiness assessment should include evaluation of key support personnel.

\section{Areas Needing Improvement}

\section{Project Schedule}

- The project completion date was determined prior to scoping, planning, estimating, or scheduling the work. No schedule contingency was available and overtime was not able to recover the schedule for all conditions that were encountered on the project. The project had adequate budget, but did not have adequate schedule.

- Communication of MSCP commitments and milestones were not included on the BEA company priority list associated with Materials and Fuels Complex restart. This caused resource and priority issues and delayed the startup activities. Project commitments need to be tracked at the senior management level to ensure priorities and application of resources match the commitments made.

- Multiple commitments cannot be made by the company that all rely on and then compete for the same resources. The Materials and Fuels Complex Support currently has limited depth. Proper sitewide integrated planning should be utilized to assess when more qualified people are required to support the work load for operations and projects.

- Some organizations were not adequately involved in core project team meetings and schedule status updates. For example, Life Safety Systems received the vendor data and as-builts too late to be ready for system operability testing and preparation of periodic maintenance work orders. The project did a good job of communicating and interfacing with the core team; however, projects need to make an extra effort to ensure the groups that only have a small piece of scope receive early notifications and follow-up.

\section{Construction}

- Inaccurate information of existing conditions delayed some work scope. It is recommended that future jobs spend more time and effort walking down the job site before construction work begins to ensure the existing conditions are well understood. This would help keep the schedule moving along smoothly and avoid delays and down time. 


\section{Safety Basis Development}

The safety basis needed to allow partial implementation based on the scope of the project. The criticality detection and alarm system was only installed for future use, not for initial operation. The highefficiency particulate air-filtered exhaust system also was not needed for the initial operation; however, both systems were evaluated during the management self-assessment and readiness assessment for startup.

DSA updates were much more than needed for the project scope. The previous DSA really only needed minor tweaks. However, because the DSA was basically re-written, other issues that may not have been identified otherwise were brought to light. For example, the existing storage containers did not have appropriate configuration management. This issue would not have been discovered if the DSA had not been re-written.

The startup notification report is due to DOE a year ahead of time. The startup notification report was not sent until March 2012, which was approximately 6 months ahead of time. This subject is further discussed in the lessons learned from the Federal Project Director.

The plan of action must be submitted early to ensure DOE is ready for the readiness assessment and $\mathrm{s}$ the scope can be agreed upon sooner. This subject is discussed further in the lessons learned from the Federal Project Director.

\section{Earned Value Management System}

The introduction of the Earned Value Management System into the construction subcontract added scope and added several issues that needed to be worked out with the construction subcontractor:

- Earned Value Management System implementation was not well understood initially. It cost the subcontractor more than anticipated to implement, and the "inflexible" nature of the baseline made tracking construction progress challenging. It is recommended that future Earned Value Management System jobs are planned in more detail to allow better tracking of construction progress.

- Billing problems were encountered when an inflexible method of taking earned value on an activity had been selected (such as 50/50). Some items were purchased and delivered that could not be fully invoiced. This created a situation where the subcontractor had to carry the costs longer than usual, increasing the cost of financing the project. Procurements within the subcontractor's work scope should be planned with an earned value method that allows the subcontractor to be paid when the costs are realized.

- BEA mandated the use of a specified schedule of values in the bid package. It is recommended that for future that projects managed under the Earned Value Management System, the work breakdown schedule and schedule of values be generated by the construction subcontractor and incorporated into the baseline, rather than developed before hand and included in the bid documents.

\section{Closeout}

- The scope associated with project closeout was not well defined and broken down into enough specific activities. The entire closeout process needed to be broken down into lower level activity detail to ensure all items were performed, accurately tracked, and reported.

\section{Significant Lessons Learned}

- The positive lessons learned from using safety pauses when needed is to recognize that following the safety pause, the project restarted and all work was accomplished without incident through completion. Projects should not hesitate to stop work and review safety conditions, work processes, or work conditions whenever the team recognizes such a need, in spite of schedule pressure. 
- As a positive lessons learned, projects should include adequate budget for essential work discipline support during construction, because the support will be needed. If adequate budget for support is not in the baseline, the project will risk going over budget during execution and missing schedule milestones. As a positive lessons learned, the project included adequate baseline funding to ensure each area of work scope was supported through all phases of the project. The project made certain that the cost baseline included funding for support from all disciplines that would be needed.

- As a positive lessons learned, quality actively participated with the fabricators of procured equipment to ensure compliance prior to fabrication, during testing, and approved the release for shipping. Once equipment has been delivered onsite, rework is expensive; therefore, the benefit to the project is to minimize rework. This approach saves costs and, especially, schedule. If equipment is delivered without being tested first, it may need to be returned to the factory for rework, causing excessive delays to the project schedule.

- As an area of improvement, the project completion date was determined prior to scoping, planning, estimating, or scheduling the work. No schedule contingency was available and overtime was not able to recover the schedule for all conditions that were encountered on the project. The project had adequate budget, but did not have adequate schedule. This resulted in additional costs for overtime and, in some cases, resulted in rework caused by trying to perform tasks too early. An example was the red-lined drawing submittals from the subcontractor. Piece meal packages were sent in, but once all work was completed, the packages required rework for final integration.

- As a positive lessons learned, the project team should be willing to investigate the best procurement method for the particular scope. An open bid may be appropriate in most cases; however, in the case of MSCP, a pre-qualified bid list helped ensure that the project team could gain assurance prior to the bid that the potential subcontractors were qualified for the work, understood the risks, and were prepared to execute the work to meet the project schedule

\section{Startup/Readiness Assessment Lessons Learned}

The management self-assessment/readiness assessment lessons learned were developed jointly with the Federal Project Director. The final comments from the Federal Project Director are as follows:

\section{Federal Project Director Key Lessons Learned}

There were several issues in planning and carrying out the readiness reviews for the project that can be great lessons learned for future projects. These issues included the start-up notification report and the process for its approval, development and approval of implementation plans that are tailored for the readiness review, management buy-in and support for readiness reviews, preparations for readiness reviews, and removal of resources prior to readiness reviews.

The start-up notification report is required by DOE Order 425.1D, "Verification of Readiness to Start Up or Restart Nuclear Facilities," to project ahead by 1 year any readiness reviews. The start-up notification report is the first step in the approval process by DOE for the level of readiness review to be required for the activity. For line item capital projects that may take multiple years for initial planning through project completion, this may not be enough time to successfully plan and implement the large project or the activity's readiness reviews. For a line item capital project, the preliminary project execution plan for CD-1 requires the level of readiness review to be preliminarily determined. By CD-2, the completed preliminary project execution plan needs to define the level of review, the resources and schedule for accomplishment need to be included into the cost estimate, and the resource-loaded schedule needs to be in development for approval of the performance measurement baseline and should include the completion of the start-up notification report by CD-2 and the plan of action by CD-3 for line item capital projects. 
In the case of MSCP, the start-up notification report with required level of readiness review was not developed and approved prior to the performance measurement baseline. During development of the preliminary project execution plan for MSCP, the Federal Project Director and BEA Special Nuclear Material Program Manager discussed the level of readiness review required and placed their determination into the preliminary project execution plan. The review for approval of the preliminary project execution plan did not have sufficient operational review to recognize the level of readiness review in the document and start preparing a start-up notification report. During development of the project execution plan and performance measurement baseline, the requirements for the readiness reviews were not fully developed or recognized by operational review of project documents and impacts on schedule and cost were not incorporated into the baseline. The development of the start-up notification report, the follow on development and approval of implementation plans, and preparation for the readiness reviews were not part of the schedule.

The approval process of the start-up notification report by both DOE and BEA needs improvement. The start-up notification report is a way to achieve management buy-in and support of both DOE and BEA management for the project, while developing the performance measurement baseline. The start-up notification report was not created until after the performance measurement baseline was approved and did not afford management buy-in and support. The Federal Project Director is not on distribution of the start-up notification report. The start-up notification report lists the start-up approval authority and the schedule for delivering the implementation plans for approval. The start-up notification report was delivered well after the 1-year requirement from DOE Order 425.1D.

The start-up notification report lists the delivery schedule for the plan of action for the readiness reviews. The plan of action for a line item capital project should be completed by CD-3. The delivery date for the plan of action in the start-up notification report was not met by BEA and was delivered approximately 1 month prior to the scheduled start date for readiness reviews. The Federal Project Director developed a plan of action that met the schedule in the start-up notification report. The development of a plan of action is an opportunity to tailor the requirements for the readiness reviews. Late delivery of the plan of action did not afford the negotiated tailoring of the readiness reviews between project staff, readiness review team leaders, and the Federal Project Director. In addition, the plan of action requires approval by both DOE and BEA management. With the late delivery of the plan of action, management support and buy-in was not acquired until right prior to the readiness review.

For large line item capital projects, the acquisition and training of a readiness review team to perform a tailored review requires significant planning well in advance of the scheduled start date. For MSCP, with late delivery of the plan of action (which is required for development of an implementation plan), the readiness review team leaders did not have adequate time to perform training or develop a tailored implementation plan. For MSCP, BEA provided a combined plan of action and implementation plan. DOE provided a separate plan of action developed by the Federal Project Director and implementation plan developed by the DOE readiness assessment team leader. Approval of a separate BEA implementation plan well in advance of the readiness reviews would have provided another opportunity for BEA management to support and buy into the readiness reviews.

BEA operations managers had determined both resource and funding constraints that would affect MSCP that were not communicated in a timely manner. After approval of readiness review implementation plans, BEA operations managers determined that there was a resource conflict with operational staff. The resource conflict with operational staff should have been determined at an earlier date and communicated to DOE and BEA management to afford them the opportunity to change priorities for the project or operational activities. BEA operations managers decided to not fund operational activities (material movement) after construction completion for starting up the facility until late in Fiscal Year 2013 at the earliest. Because BEA operations managers decided to not perform material movements until significantly after construction completion, several operational activities required for completing 
readiness activities in support of readiness reviews and achieving the start of operations were not performed (e.g., emergency management planning and transportation plans).

The Performance Evaluation Measurement Plan required completion of a DOE readiness assessment and the facility turned over to operations by September 30,2012. BEA operations managers changed their priorities for operations in the facility once construction was complete, without taking into account the Performance Evaluation Measurement Plan requirement or the requirements in the project execution plan.

After development of the performance measurement baseline, DOE management decided to add additional work scope to the project. After several iterations of different work scopes, BEA was directed to develop cost estimates and an updated performance measurement baseline to the additional work scope. The length of time for development of a baseline change proposal is lengthy. While the baseline change proposal was being approved, DOE management decided to use funding for additional work scope for other activities.

\section{Key Lessons Learned}

For line item capital projects or general plant projects that could have significant startup or readiness review requirements, the following are key lessons learned from MSCP:

1. DOE Order 425.1D requires the startup notification report to incorporate planned readiness activities for projects 1 year in advance, which may not be sufficient for large or complex projects or activities to thoroughly plan and prepare for readiness activities.

2. The startup notification report should be drafted by CD-1 and finalized by CD-2 to ensure proper resources and readiness review requirements are incorporated into the project execution plan and into the performance measurement baseline.

3. The plan of action for readiness reviews should be completed by CD-3 to allow time to properly tailor readiness review requirements and plan for resources to complete all activities to be ready.

4. The implementation plan for readiness reviews should be completed shortly after approval of the plan of action to ensure there is time to train and prepare the review teams to the tailored approach for the review.

5. The plan of action and implementation plan for readiness reviews need to be separate and distinct documents.

6. The startup notification report, plan of action, and implementation plan for readiness activities need to be well in advance of the start of readiness review activities to afford contractor and DOE management time to buy-in and support readiness review requirements and assure availability of resources.

7. The Federal Project Director for a project should be on distribution for the startup notification report, plan of action, and implementation plan. 


\section{Appendix D, Design Phase Post-Project Review/ Lessons Learned Report}

\section{Summary}

The MSCP design phase was on a very short time schedule. In order to achieve the schedule, creative ways to complete the work had to be devised. A concept to perform all reviews concurrently was developed, scheduled, and implemented with success. The schedule was met and CD-2/3 approval obtained.

\section{Design Review}

The design review required and provided formal comment resolutions. All resolutions were documented in a final design review report.

There were no "show stopper" comments from the reviewers involved in the design review and all comments were easily resolved. Many comments were resolved real time as the review was progressing. This gave the project team confidence in the final design. Several actions, including the following, by the project team helped lead to this result:

- A value engineering session was held during design, providing confidence that the risks were being adequately considered. Solutions to design questions and challenges were accepted by the project team.

- Integrated project team meetings were held where all personnel from affected disciplines were made cognizant of the project scope, drivers, schedule, and goals.

- The design review schedule was emphasized and followed. The dates for the design review, comment resolution, design review closeout, comment incorporation, and final publishing of the design were calendared ahead of time for the reviewers and the project team. The schedule was met.

- Instructions to the reviewers were clear. They were to review the design against the approved scope, not question the scope, or come up with new approaches. The comments were limited to compliance issues or items driven by orders. This is described by the phrase, "There lots of ways to skin this cat, but all we want is a skinned cat, and we have already defined the way" (Ron Gill).

\section{Concurrent Reviews}

The date for the design review was scheduled in May 2011, when the post CD-1 schedule was published. August 4 was the date established to start the design review. The final design was to be published by August 25 and the CD-2/3 package would be compiled and submitted. In order to publish the design and the CD-2/3 package, several activities needed to be completed, including the following:

- Design review

- The approved for construction cost estimate

- The DOE independent cost estimate

- Technical independent project review

- Independent project review.

In order for these multiple reviews to be accomplished in the short schedule, the reviews had to be held concurrently. All of the above reviews were started with draft documents. This required that the reviewers be flexible and open minded. They had to be willing to perform their reviews using draft 
documents, with the understanding that all comment resolutions would be incorporated into the design at completion of the reviews.

Prior to the review, all reviewers needed to be cognizant of the project scope. The reviews had to begin with the review teams already being familiar with the project scope and design. It was absolutely essential that the project management team made sure that there were no reviewers that would be surprised by the project. The project management team had to be certain that all the individuals from affected disciplines had been educated and informed of the project prior to the start of the reviews.

The schedule for the reviews was made clear to the reviewers. The ability of the reviewers to meet the schedule was enhanced because the project scope and design decisions had been presented in the integrated project team meetings.

The short, but definitive, schedule forced decisions, rather than allowing time for issues to languish and become stagnant.

\section{Other Concepts, Actions Taken, and Discussion}

A lot of what we were able to do was made easier because of the priority placed on this project by DOE Idaho Operations Office and Congressman Simpson's office. Projects compete for resources and priority; having such a high priority helps the project get a better response from managers and performers.

The independent cost estimate performers had the draft CD-1 documents a month ahead of the design review date, allowing them to become familiar with the project and set up their cost estimate templates ahead of time.

The project management team limited the reviews to the essential documents. The reviewers needed to see the essential information and perform the review based on the requirements. Additional information could have been provided, but that could have resulted in extra work and comments, with no substantial value added. The information was controlled to that which was essential in order to keep the review well focused.

The DSA team did onsite walk downs to ensure they were familiar with the scope of the project and to help them better comprehend the overall project. This helped the safety analysts envision the areas they were describing and working on.

Team continuity was essential to the accelerated schedule. The design lead and cost estimator were the same individuals that participated in the conceptual phase of the project. Specific efforts were made to ensure the same individuals would be available.

Independent breakout discussions with various disciplines affected by the project (such as nuclear safety, environmental, construction, procurement, and others) helped ensure that specific concerns from each discipline were identified and resolved prior to the start of the reviews.

\section{Cautions and Risks}

The project needed to be sure to scrub the documents thoroughly to ensure no old information still showed up in the documents. Also, the project needed to avoid replication of the same information in multiple documents. Having information repeated in multiple places creates the possibility of inconsistencies and makes revisions much more difficult.

The accelerated schedule required that the project accept more risk of errors in design, cost estimating, or other areas of the project. The project ensured that adequate management reserve and contingency was available in such cases.

The readiness assessment was defined as early as possible to ensure all activities were captured. A final review of the baseline plan for accomplishing the DSA work was needed to ensure all participants were identified. 


\section{Conclusions}

The accelerated schedule was successfully met through concurrent reviews. The key actions that ensured success were as follows:

- Management support

- Integrated team involvement and cooperation

- Schedule management

- Scope control

- Flexibility.

This method of project execution can be successful and can reduce the overall duration of the project. The key is involvement of the integrated project team with well-defined goals and constant communication. 


\section{Appendix E, Executed Transition to Operations Plan}

Document ID: PLN-4173

Revision ID: 1

Effective Date: $10 / 11 / 2012$

Transition to Operations Plan

Project No.: 30050

Material Security and
Consolidation Project

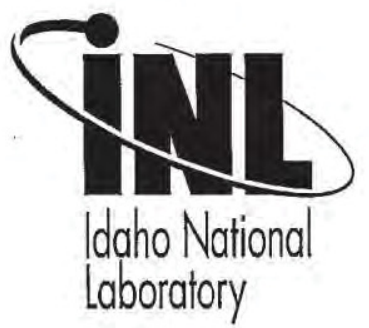

The INL is a U.S. Department of Energy National Laboratory operated by Battelle Energy Alliance.

Laboratory 
REVISION LOG

\begin{tabular}{|c|c|c|l|}
\hline Rey. & Date & Affected Pages & \multicolumn{1}{c|}{ Revision Description } \\
\hline 0 & $6 / 11 / 2012$ & AlI & Newly issued document \\
\hline 1 & $10 / 11 / 2012$ & All & $\begin{array}{l}\text { Revised to include PEP changes to CD-4 } \\
\text { requirements }\end{array}$ \\
\hline & & & \\
\hline & & & \\
\hline & & & \\
\hline & & & \\
\hline & & & \\
\hline & & & \\
\hline & & & \\
\hline
\end{tabular}


Faemulizog (Hev, 10)

Idaho National Laboratory

MATERIAL SECURTYY AND

CONSOLIDATION PROJECT

Identifier. PLN-4173

Revision: 1

Effective Date: 10/11/2012 Page: iv of yiii

Transition to Operations Plan for Material Security and Consolidation Project

Project Number: 30050

Reviewed By:

Nal Russell per imail

Neal Russell

Design Authority

for Lisa Harvego

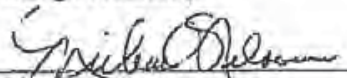

Project Management Review Board

Randy Heyrend per emaif

Randy Ileyrend

Project Engineer

Alan Garvo ser email

Alan Caryo

Program Environmental Lead

Morite Lamb per email

for Lex Strain

Construction Manager

Approved by:

Her Meler for

Lannie Workman

Project Manager

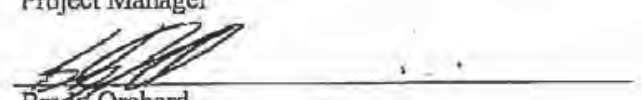

Braff Orchard

$$
\text { er }
$$

$10 / 11 / 12$

Date

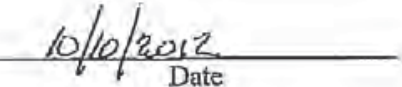

$10 / 11 / 2012$

Date

10/10/20/2

Date

$10 / 10 / 2012$

Date

INL. Program Manager

G wen Borschel per email

Gwen Borschel

Nuclear Facility Manager/Owner

$10 / 10 / \frac{2012}{\text { Date }} 1 / 1 / 12$

Date 


Idaho National Laboratory
\begin{tabular}{|l|lll|}
\hline MATERIAL SECURITY AND & Identifier: & PLN-4173 & \\
CONSOLIDATION PROJECT & Revision: & 1 & \\
Effective Date: & $10 / 11 / 2012$ & Page: v of viii \\
\hline
\end{tabular}
CONTENTS

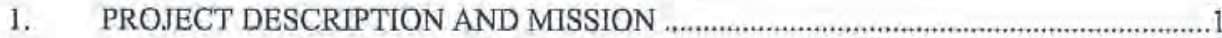

2. PLANNING MANAGEMENT, ORGANIZATION, AND CONTROL ...........................

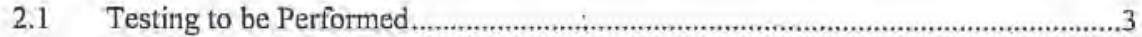

2.2 Beneficial Occupancy/Substantial Completion ..................................................4

2.3 Project Tumover …........................................................................................4

2.4 Startup, Construction Component Testing, System Operability Testing, Management Self Assessment, and Readiness Assessment(s) ...............................5

2.5 Nuclear Facility Checkout, Testing, and Commissioning .................................6

2.6 Operations and Maintenance Manuals/Procedures .............................................6

2.7 Spares Identification and Procurement............................................................... 7

2.8 Operations Staffing, Training, and Readiness ................................................... 7

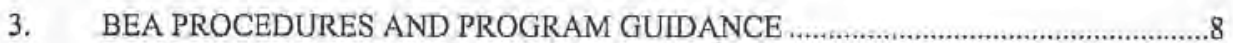

4. KEY TRANSITION PHASE STEPS AND DELIVERABLES .......................................

4.1 Regulatory Agencies and Other Stakeholders Agreements ..................................9

4.2 Transition Phase Deliverables (Include the List of CD-4 Prerequisites) .................9

4.3 Transition Phase Steps and Deliverables ..........................................................

5. ORGANIZATIONS, STAKEHOLDERS, AND PUBLIC INTERFACES ....................9

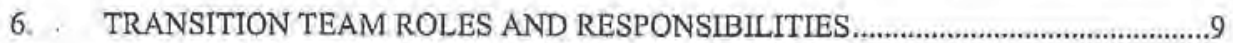

6.1 System Operability Test Engineer …..................................................................

6.2 System Operability Test Leader.................................................................... 10

6.3 System Operability Test Team Members .........................................................10

6.4 Management Self-Assessment Lead.............................................................

6.5 Management Self-Assessment Team Members.................................................10 


\begin{tabular}{|lll|}
\hline Identifier: & PLN-4173 & \\
Revision: & 1 & \\
Effective Date: & $10 / 11 / 2012$ & Page: vi of viii \\
\hline
\end{tabular}

6.6 Contractor Readiness Assessment Lead ..............................................................10

6.7 Readiness Assessment Team Members …...................................................... 10

6.8 DOE Readiness Assessment ….....................................................................

7. OPERATIONS REQUIREMENTS TO SUPPORT TRANSITION FROM THE

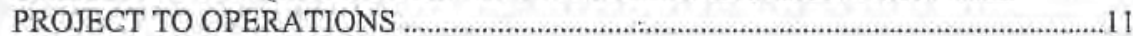

7.1 Integration of Operations Needs into Project Schedule .........................................11

7.2 Prepare an Operations Budget …....................................................................

8. PROIECT KEY PERFORMANCE ELEMENTS AND COMPLETION CRITERIA

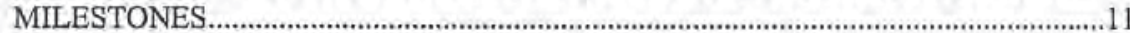

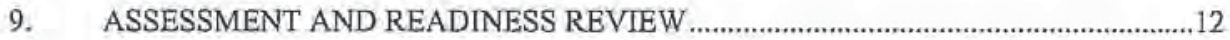

9.1 Facility Hazard Categorization ......................................................................12

9.2 Checkout, Testing, and Conmissioning .........................................................12

10. FACILITY SUPPORT, OPERATIONS, AND MAINTENANCE TRAINING .............13

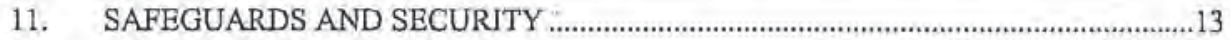

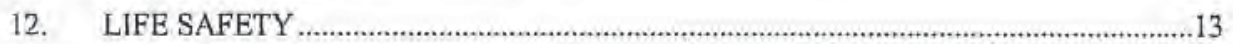

13. EMERGENCY PREPAREDNESS

14. AUTHORIZATION AND NOTIFICATION...............................................................

15. PROJECT ACCEPTANCE, BENEFICIAL OCCUPANCY, AND TRANSFER TO

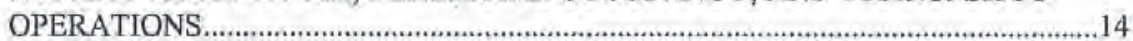

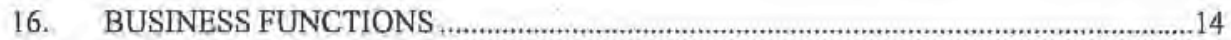

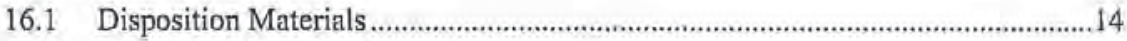

16.2 Project Transfer Form Distribution................................................................. 14

17. PROJECT INFORMATION AND RECORDS TURNOVER ......................................15

18. TRANSITION TO OPERATIONS NOTIFICATION

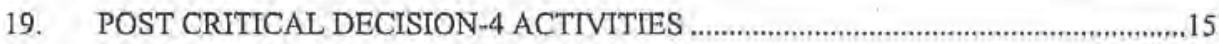




\begin{tabular}{l|lll|} 
MATERIAL SECURITY AND & Identifier: & PLN-4173 & \\
CONSOLIDATION PROJECT & Revision: & 1 & \\
& Effective Date: & $10 / 11 / 2012$ & Page: vii of viii \\
\hline
\end{tabular}

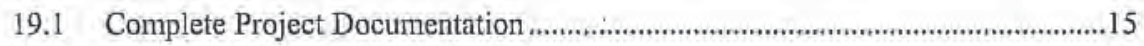

19.2 Support Department of Energy PARS II Reporting ..........................................15

19.3 Prepare the Lessons Learn Document...................................................................15

19.4 Obtain Leadership in Energy and Environmental Design Certification ................16

19.5 Notify 10-Year Site Plan of Project Status ........................................................16

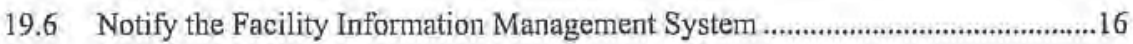

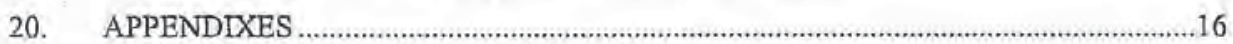

Appendix A, Checklist for Partial Project Transfer........................................................

Appendix B, Checklist for Final Project Transfer .......................................................18

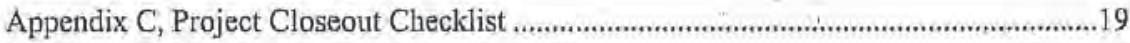


MATERIAL SECURITY AND

Identifier:

Revision:

PLN-4173

CONSOLIDATION PROJECT

Effective Date: $10 / 11 / 2012$

Page: viii of viii

\section{ABSTRACT/SUMMARY}

This transition to operations plan covers transition of the material security and consolidation project from construction to operations. 


Idaho National Laboratory
\begin{tabular}{|l|lll|}
\hline MATERIAL SECURITY AND & Identifier: & PLN-4173 & \\
CONSOLIDATION PROJECT & Revision: & 1 & \\
Effective Date: & $10 / 11 / 2012$ & Page: 1 of 20 \\
\hline
\end{tabular}

\section{PROJECT DESCRIPTION AND MISSION}

As stated in the approved DOE project execution plan, the Idaho National Laboratory's missions (INL) related to nuclear energy technologies with the Department of Energy (DOE) Office of Nuclear Energy continue to grow. Additional onsite storage to support planned disposition activities for sodium-bonded spent fuel is now essential to consolidate the site's inventory of spent nuclear fuel as required to support the 1995 Settlement Agreement between the State of Idaho and DOE.

The Material Security and Consolidation Project (MSCP) is the preferred alternative as approved by critical decision (CD)-1 to the specific need for additional onsite storage for sodium-bonded spent fuel disposition product, which is considered to be low-enriched uranium (LEU). This project will meet the mission need for additional storage of LEU disposition product from the processing of sodium-bonded spent fuel to be stored in the CPP-651 facility at the Idaho Nuclear Technology and Engineering Center (INTEC). This LEU is currently stored in the Transient Reactor Experiment and Test Facility warehouse. Starting in Fiscal Year 2010, the disposition activities increased into production levels. The current INL storage locations are limited to accommodate this increased production without impacting ongoing missions. The refurbishment of CPP-651 will support a nuclear material storage location to accommodate this LEU. Modifications will be made to CPP-651 to provide storage of the LEU, up to and including Hazard Category II quantities of nuclear material.

Modifications to the facility include the installation of perimeter security fence and security features, LEU handling equipment, new security door, installation of a crane in the north storage vault, and facility entry vestibule. TNTEC-651 is not a fully occupied facility and has primary function of being a storage facility for nuclear material.

The approved CD-2/3 establishes the performance measurement baseline for the project. The total project cost, including contractor management reserve and DOE contingency, is $\$ 17,418,774$. The schedule dates for CD-0 through CD-4 are shown in Table 1 .

Table 1. Material Security and Consolidation Project schedule.

\begin{tabular}{|l|l|}
\hline CD-0, Approve mission need & December 14,2010 \\
\hline CD-1, Approve alternative selection and cost range & April 27, 2011 \\
\hline $\begin{array}{l}\text { CD-2/3, Approve performance baseline and start of } \\
\text { construction }\end{array}$ & September 2011 \\
\hline CD-4, DOE Approve Project Completion & November 2012 \\
\hline
\end{tabular}

\section{PLANNING MANAGEMENT, ORGANIZATION, AND CONTROL}

Development of this plan was completed with input from all stakeholders including project/program management, design engineering, safeguards and security, nuclear 


\begin{tabular}{|lll|}
\hline Identifier: & PLN-4173 & \\
Revision: & 1 & \\
Effective Date: & $10 / 11 / 2012$ & Page: 2 of 20 \\
\hline
\end{tabular}

safety/safety analysis, criticality safety, classification, nuclear operations/facility management, operations engineering, maintenance, radiological controls, construction management, environmental support, quality, procurement, environmental safety and health, emergency management, packaging and transportation, records management, communications, information teclinology, life safety systems, fire protection, and the operating company at INTEC, CWI.

The detailed schedule and budget required for construction and transition of the facility to operations is included in the MSCP baseline. The overall approach for transition to operations includes the following major steps:

- Installation of equipment, facility modifications, and applicable construction subcontractor testing completed by a construction subcontractor as described in SPC-1414, "Construction Specification - Material Security and Consolidation Project"

- Partial project turnover from the construction subcontractor to BEA

- Completion of system operability (SO) testing

- Preparation of all necessary operating and maintenance procedures

- Implementation of the approved documented safety analysis (DSA)

- Final Project Transfer of all systems and subsystems needed to support the MSA and RA for low-enriched uranium (LEU)/spent fuel treatment product (SFTP) receipt and storage

- Completion of a BEA management self assessment (MSA) and readiness assessment (RA) for LEU/spent fuel treatment product (SFTP) receipt and storage

- Final Project Transfer of all remaining systems and subsystems

- Completion of a DOE RA

- Submittal of the transition to operations notification

- Assembly and submittal of the CD-4 package to DOE

- DOE approval of project completion

- Project Closeout. 
The key performance elements were identified in the MSCP PEP. They include the following (see Section 8 for additional details):

- Provide storage for nuclear materials that meet applicable DOE safety and security requirements for LEU while maintaining the OESTD-1020, ${ }^{\text {TN}}$ Natural Phenomena Hazards Design and Evaluation Criteria for Department of Energy Facilities," Performance Category-3 structure.

- Install a second egress route/entrance into CPP-651 that meets DOE O 473.3 requirements for protection of CAT-IV special nuclear material (SNM) that does not preclude future upgrades to CAT-I SNM storage with SNM vaults, vault door, wall penetrations, and intrusion detection and assessment systems.

- Install and operate an SNM monitor, metal detector, argus access panel, cameras and motion sensors (evaluated and replaced as necessary)

- Life safety upgrades, including the second egress route that is compliant with the life safety code as approved by the Authority Having Jurisdiction to permit occupancy limits that enable the needed staffing levels to work in the facility during operations.

- Complete a DOE readiness assessment that includes, but is not limited to, evaluation of the following such that the facility can safely and efficiently initiate muclear material storage operations: 10 CFR 830-compliant DSA, operating procedures, CPP-651 staffing and training of operators, equipment operability.

The following sections provide additional details regarding testing to be performed, beneficial occupancy, startup testing, assessments of readiness and other issues to be resolved in support of the transition of the applicable facilities from construction to operations.

\subsection{Testing to be Performed}

Prior to partial project turnover, the installed equipment will be tested by the construction subcontractor as described in SPC-1414, "Construction Specification - Material Security and Consolidation Project (MSCP)." The results of the applicable construction subcontractor equipment testing will be used to demonstrate that the installed equipment and building modifications meet the design criteria.

Following partial project turnover, additional testing will be performed by the Technical Security organization (SO testing of the security systems), and Materials and Fuels Complex (MFC) Nuclear Operations (SO testing of the operations equipment) with the assistance of BEA System Engineering. To the 


\begin{tabular}{|lll|}
\hline Identifier: & PLN-4173 & \\
Revision: & 1 & \\
Effective Date: & $10 / 11 / 2012 \quad$ Page: 4 of 20 \\
\hline
\end{tabular}

extent possible, applicable consiruction subcontractor equipment tests will be used to satisfy system operability and integrated testing requirements.

Additional details related to testing are in section 2.4.

\subsection{Beneficial Occupancy/Substantial Completion}

Beneficial occupancy is completed when the partial project transfer form (form $432.04)$ is executed.

\subsection{Project Turnover}

Project Turnover is turnover of the completed construction of the project, which means transferring care (operating and maintenance responsibility), custody (responsibility for the facility), and control (directing and managing facility operations, maintenance, and programmatic integration with sponsors) from the construction subcontractor to BEA operations. To enable partial and final turnover of the project, the following items need to be accepted.

\subsubsection{Partial Project Turnover}

A project turnover review cormmittee will perform a turnover of each system as the construction work on it is completed. The committee will consist of the following disciplines as needed for each system: project manager, control account manager, nuclear facility manager, facility staff, system engineer, construction manager, quality assurance, ES\&H, and the system engineer for each system as shown in Table 2. The project manager will identify the personnel on the turnover review committee for each partial project turnover.

Table 2. System turnover list.

\begin{tabular}{|ll|}
\hline \multicolumn{1}{|c|}{ System } & \multicolumn{1}{c|}{ System Engineer } \\
\hline Building Fire Protection System & Neal Russell \\
All Other Building Systems Including & Neal Russell \\
Roads and Grounds & \\
Telecommunications & Susan Giliring \\
Life Safety Systems & Scott MoMurtrey \\
Security Systems & David Sommercorn \\
\hline
\end{tabular}

The Project Turnover Review Committee will complete the readiness checklist for partial project transfer (see Appendix A) as facilities and systems are completed to ensure completion of all necessary activities. before approving the partial project turnover. 
Upon completion of the partial project transfer, a punch list will be generated from construction zone walkdown by the turnover review committee (as identified by the project manager for each partial project transfer). The walk down will identify punch-list items and occupancy safety issues. A Project Deficiency Status Report or punch list (Form 423.68) will be generated.

\subsubsection{Final Project Transfer}

Final project transfer from the BEA project to the BEA facility owner will be completed as systems and modified facilities are completed. Final transfer will occur as individual systems and subsystems are completed. Final project transfer will be completed after all work installation, testing, and documentation bave been completed in preparation for the final project transfer. The Facility/System Turnover Review Committee will use a detailed readiness checklist on the project punch list that includes all items that must be completed before final project transfer (see Appendix B). The completed checklist will function as the facility acceptance review report. All items on the checklist will be completed before final project transfer, unless the Facility Manager determines the system or systerns can be accepted with a completion plan in place for items that are deficient.

The completed punch lists including the readiness checklists, signature sheets, and documentation lists will constitute the project turnover committee review and the Project Management Review Board report.

\subsection{Startup, Construction Component Testing, System Operability Testing,} Management Self Assessment, and Readiness Assessment(s)

Completion of startup, applicable construction subcontractor equipment testing, SO testing, MSA, and RAs are described in the following sections.

2.4.1 Startup and construction subcontractor equipment testing will be performed by the construction subcontractor and witnessed (if required) by BEA System Engineers as described in SPC-1414, the applicable construction specification. To the extent possible, applicable construction subcontractor equipment testing will be used to satisfy system operability $(\mathrm{SO})$ testing requirements.

2.4.2 BEA System Engineers/SO Test engineer will complete $\mathrm{SO}$ testing of other equipment identified on the project SO test list (in the project file),

2.4.3 BEA Security will install and perform startup and initial equipment testing (if applicable) for all security-related instrumentation. 


\begin{tabular}{|lll|}
\hline Identifier: & PLN-4173 & \\
Revision: & 1 & \\
Effective Date: & $10 / 11 / 2012$ & Page: 6 of 20 \\
\hline
\end{tabular}

2.4.4 The startup readiness checklist was been completed and submitted to DOE (See letter CCN 226879). In response to the checklist,' DOE indicated that an RA will be performed (Approval OS-QSD-12-020).

2.4.5 The MSA and contractor RA will be completed following completion of all required startup, applicable construction subcontractor equipment testing, and SO testing as described above. The MSA and RA will be conducted as described in the MSA and RA Plans that will be prepared under the direction of the nuclear facility manager.

NOTE: The CPP-651 air exhaust system modifications (also known as the HEPA system), criticality alarm system (CAS), and the uninterruptible power supply (UPS) in CPP-1674 will not be included in the MSA and RA. Completion of these systems will be documented by a final project transfer.

\subsection{Nuclear Facility Checkout, Testing, and Commissioning}

Nuclear facility checkout and testing will include the following tests and assessments:

- Applicable construction subcontractor equipment testing by the construction subcontractor or BEA Security

- $\quad$ SO Testing

- Implement the approved documented safety analysis (SAR/TSR-416)

- $\quad$ MSA by BEA Operations and System Engineering for SFTP receipt and storage

- $\quad$ RA by BEA Operations for SFTP receipt and storage

- RA by DOE-ID.

Commissioning consists of the verification that the installed or modified systems function properly. During SO testing, operability of nuclear systems will be verified with radioactive sources. Final hot testing of the installed or modified equipment installed by the MSCP will be accomplished after CD-4 by nuclear facility operations and is not part of the MSCP work scope.

\subsection{Operations and Maintenance Manuals/Procedures}

Both operations and maintenance manuals and procedures will be required to support facility operations and are included in the MSCP scope. 


\begin{tabular}{|lll|}
\hline Identifier: & PLN-4173 & \\
Revision: & 1 & \\
Effective Date: & $10 / 11 / 2012$ & Page: 7 of 20 \\
\hline
\end{tabular}

\subsubsection{Operations and Maintenance Manuals}

In all cases, operations and maintenance manuals will be supplied by the equipment manufacturer and installed by the construction subcontractor. The manuals are identified in SPC-1414 and are submitted as vendor data. The nuclear facility manager, system engineer, and other appropriate reviewers will comment on the content of the manuals before they are accepted by BEA.

\subsubsection{Operations and Maintenance Procedures}

Several procedures are required to operate the facility. The development of these procedures is included in MSCP scope. The nuclear facility manager will support the project by developing the operations and maintenance procedures.

\subsection{Spares Identification and Procurement}

The construction subcontractor will develop a list of required spares for all installed equipment as deseribed in SPC-1414, The MSCP scope includes procurement of critical spares. Procurement of critical spares will be accomplished by the nuclear facility manager's organization with MSCP-provided funding. Since Phase 2 of this project bas been cancelled, procurement of spare probes for the CAS and other non-critical spares is not MSCP scope.

\subsection{Operations Staffing, Training, and Readiness}

The nuclear facility manager has identified required operations staff. Operations staff bas been included in various phases of design and construction to facilitate final turnover of the facility to operations. Required activities that included in MSCP scope are described in the following sections.

\subsubsection{Operations Staff}

Operations staff required to operate the facility were identified by the facility manager based on previous experience with operating similar facilities.

\subsubsection{Operations Staff Training}

The BEA training organization will assist the nuclear facility manager to develop appropriate training. Operations staff will be trained to operate the equipment in accordance with approved procedures. 


\begin{tabular}{|ll|}
\hline Identifier: & PLN-4173 \\
Revision: & 1 \\
Effective Date: & $10 / 11 / 2012 \quad$ Page: 8 of 20 \\
\hline
\end{tabular}

\subsubsection{Declaration of Operations Personnel Readiness for Project Turnover}

Following successful training and walkthroughs, MFC operations will conduct an internal review of operators. Following the internal teview operating personnel will be qualified as facility custodians. It is anticipated that this will occur when the DSA is implemented (DSA implementation is identified as an activity in the MSCP scope).

\section{BEA PROCEDURES AND PROGRAM GUIDANCE}

DOE/ID PLN-2011, "Project Execution Plan for Material Security and Consolidation Project," Project: 08-D-702, September 2011

Environmental Checklist, EC Document Number INL-11-003, "EC Facility Construction and Modification in Support of the Material Security and Consolidation Project., Jamuary $27,2011$.

Form-415.43, "Project Closeout Checklist"

MCP-7001, "Management of Projects"

LWP-7201, "INL Construction"

LWP-10107, "Engineering Test Control"

MCP-7460, "Project Turnover, Acceptance, and Closeout"

Riley R. Chase letter to Raymond V. Furstenau, Contract No. DE-AC07-05ID14517 Startup and Restart of Nuclear Facilities, Startup Notification Report, Quarterly Update, March 14, 2012, CCN226879

SPC-1414, "Construction Specification Material Security Consolidation Project (MSCP)," Revision 0, August-30, 2011

SAR-416, Safety Analysis Report for the Material Security and Consolidation Project, June, 2012 (in preparation)

TSR-416, Technical Safety Requirements for the Material Security and Consolidation Project, June, 2012 (in preparation)

TFR-578, "Technical and Functional Requirements Material Security and Consolidation Project," Revision 1, August 23, 2011 


\begin{tabular}{|lll|}
\hline Identifier: & PLN-4173 & \\
Revision: & 1 \\
Effective Date: & $10 / 11 / 2012$ & Page: 9 of 20 \\
\hline
\end{tabular}

\section{KEY TRANSITION PHASE STEPS AND DELIVERABLES}

\subsection{Regulatory Agencies and Other Stakeholders Agreements}

No special permits are required to construct or operate the facility (such as air quality permits or a permit to construct.) An environmental checklist, INL-11003, "Facility Construction and modification in Support of the Material Security and Consolidation Project," was performed for the project's work scope, which documents BEA's environmental compliance to environmental laws, rules, and regulations. The specific work activities evaluated in the environmental checklist. include:

- Facility infrastructure modifications

- Facility security modifications

- Storage of recovered LEU from sodium-bonded fuel treatment.

4.2 Transition Phase Deliverables (Inelude the List of CD-4 Prerequisites)

The project will use the checklist in Appendix C to track and complete transition phase deliverables.

\subsection{Transition Phase Steps and Deliverables}

Transition phase steps and deliverables, including preparation of operations and maintenance procedures, training for operators, proposed SO testing, and MSA and RA, are included in the MSCP project scope and are being performed by MFC nuclear facility operations. A summary of the transition phase steps and deliverables are described in Section 2.

\section{ORGANIZATIONS, STAKEHOLDERS, AND PUBLIC INTERFACES}

The project execution plan includes a communications plan. This plan will be used for all interfaces associated with project closeout activities.

\section{TRANSITION TEAM ROLES AND RESPONSIBILITIES}

The MSCP scope includes completion of the following transition team roles and responsibilities.

\subsection{System Operability Test Engineer}

See Table 2, (page 4) for a list of responsible SO test engineers for each system. The test engineer is responsible for preparing the SO test (if required) and completing the test. The testing may be accomplished by the SO test engineer. 


Idaho National Laboratory
\begin{tabular}{|l|lll|}
\hline MATERIAL SECURITY AND & Identifier: & PLN-4173 \\
CONSOLIDATION PROJECT & Revision: & 1 & \\
Effective Date: & $10 / 11 / 2012$ & Page: 10 of 20 \\
\hline
\end{tabular}

witnessing the applicable construction subcontractor equipment testing. Where applicable, testing will be performed by the construction subcontractor and witnessed by the SO test engineer as described in SPC-14I4.

\subsection{System Operability Test Leader}

The SO test engineer is also the SO test leader. See Table 2 for a list of engineers assigned to each system. Those shown in Table 2 are both the system engineer and the SO test engineer.

\subsection{System Operability Test Team Members}

SO test team members will be assigned by the applicable SO test engineer. Team members will generally be individuals with a working knowledge of the system or equipment being tested.

\subsection{Management Self-Assessment Lead}

The assigned nuclear facility manager working with the MFC startup manager will identify an MSA lead. The nuclear facility manager is responsible for coordinating and carrying out the MSA and will prepare an MSA plan to support this work. All work associated with the MSA is covered in the MSCP scope.

\subsection{Management Self-Assessment Team Members}

The MSA team members will be ideritified in the MSA plan, by the MSA lead.

\subsection{Contractor Readiness Assessment Lead}

The assigned nuclear facility manager working with the MFC startup manager will identify a contractor RA lead. The nuclear facility manager is responsible for coordinating and carrying out the RA and will prepare an RA plan to support the work. All work required to complete the RA is covered in the MSCP scope.

\subsection{Readiness Assessment Team Members}

RA team members will be identified and their roles described in the RA Plan by the RA Lead.

\subsection{DOE Readiness Assessment}

Following completion of the BEA MSA and RA, DOE will perform an RA. 


\section{OPERATIONS REQUIREMENTS TO SUPPORT TRANSITION FROM THE PROJECT TO OPERATIONS}

The MSCP scope includes the activities described in this section.

\subsection{Integration of Operations Needs into Project Schedule}

Nuclear Facility Operations resource needs to complete assigned scope have been identified and included in the project scope through all project closeout activities including post-CD -4 activities. This includes staff required to complete the work required to tum over the building and prepare the facility for operation. Following CD-4 approval, MSCP scope is limited to project closeout activities as identified in the PEP.

\subsection{Prepare an Operations Budget}

The operations budget for FY-12 is identified in the MSCP scope and is covered by MSCP operating funds. Funds are provided to complete the activities described in section 2 and 6 of this report. The out year budgets (following MSCP CD-4 approval) are not included in the MSCP scope and will be developed at a later date by operations.

\section{PROJECT KEY PERFORMANCE ELEMENTS AND COMPLETION CRITERIA MULESTONES}

The key performance parameters for MSCP are to provide storage for miclear materials that meet applicable DOE safety and security requirements for LEU, while maintaining the OESTD-1020, "Natural Phenomena Hazards Design and Evaluation Criteria for Department of Energy Facilities," Performance Category-3 structure. The project's key performance parameters are described in the following paragraphs.

The security vestibule to CPP-651 for a second egress route/entrance is constructed so the egress route/entrance and its associated hardened security doors will meet DOE 0473.3 for protection of CAT-IV spent nuclear material (SNM) that does not preclude future upgrades to CAT-I SNM storage with SNM vaults, vault door, wall penetrations, and intrusion detection and assessment systems. The modifications include the addition of the following hardware:

- SNM monitor

- Metal detector

- Argus access panel

- Cameras and motion sensors (evaluated and replaced as necessary). 
MATERIAL SECURITY AND CONSOLIDATION PROJECT

\begin{tabular}{|c|c|c|}
\hline Identifier: & PLN-4173 & \\
\hline Revision: & 1 & \\
\hline Effective Date; & $10 / 11 / 2012$ & Page: 12 of 20 \\
\hline
\end{tabular}

The storage area for LEU disposition product in CPP-651 was constructed so the weight of the storage containers does not invalidate a Performance Category-3 seismic qualification.

The construction of the egress route/entrance into CPP-651 was constructed so the physical removal of material from the entrance does not invalidate the seismic qualification of the west facing wall of CPP-651 from Performance Category-3.

The life safety upgrades, including the second egress route, were constructed in compliance with the life safety code as approved by the Authority Having Jurisdiction to permit occupancy limits that enable the needed staffing levels to work in the facility during operations.

CPP-651 will pass a DOE readiness assessment that includes, but is not limited to, evaluation of the following such that the facility can safely and efficiently initiate LEU/SFTP nuclear material storage operations as modified by the RA Plan of Action (PLN-4130):

- 10 CFR 830-compliant DSA

- Operating procedures

- CPP-651 staffing and training of operators

- Equipment operability.

Achievement of key performance parameters will be verified through applicable construction subcontractor equipment testing, SO testing, and successful completion of the DOE RA and final project transfer documentation. The final project transfer documentation is a combination of Appendices B and C.

\section{ASSESSMENT AND READINESS REVIEW}

\subsection{Facility Hazard Categorization}

CPP-651 is a Hazard Category II nuclear facility. The MSCP scope includes activities to update the applicable DSA and perform DSA implementation activities. Before the project is completed, an MSA and RA will be conducted. DOE has approved this approach for CPP-651 (See approval OS-QSD-12-020).

\subsection{Checkout, Testing, and Commissioning}

Successful completion of the MSA and RA is described in section 2.5. Specific steps associated with the MSA and RA will be documented in the MSA and RA Plan which is being prepared by the nuclear facility manager and is covered by MSCP scope. 
MATERIAL SECURITY AND CONSOLIDATION PROJECT

\begin{tabular}{|lll|}
\hline Identifier: & PLN-4173 & \\
Revision: & 1 & \\
Effective Date; & $10 / 11 / 2012$ & Page: 13 of 20 \\
\hline
\end{tabular}

\section{FACILITY SUPPORT, OPERATIONS, AND MAINTENANCE TRAINING}

Training required to start the facility is included in the project scope. Training is anticipated to consist of classroom presentations, equipment vendor training, required reading of applicable procedures and operations manuals, and demonstrated proficiency. There are no certifications beyond the existing proficiency training for personnel supporting long-term operations.

\section{SAFEGUARDS AND SECURITY}

Safeguards and security-related activities and equipment are being installed and tested by security and are included in the MSCP scope. The final configuration and testing of the security hardware will be performed through a work order completed by security.

The project completed a vulnerability assessment (classified) and it determined that facility modifications and penetrations were acceptable. It further determined a Force on Force exercise is not required. The vulnerability assessment was performed during the design phase of the project and is verified at completion by security. Updates to the site security plan (PLN-11002) were also completed.

\section{LIFE SAFETY}

The life safety system will be installed as specified in SPC-1414, the construction specification. Testing of the system will validate that it operates as designed. Testing will be performed per the manufacturer's test instructions and the project specific test submitted and performed by the construction subcontractor. Life Safety and Fire Protection will review, approve, and witness the testing of the fire alarms and fire suppression systems. The construction subcontractor will perform the integrated test and the applicable Life Safety engineer will witness the test to verify performance (see Table 2, page 4 for assignment of the Life Safety system engineer.) Contractor test results will be entered into the project file through the vendor data system.

\section{EMERGENCY PREPAREDNESS}

Emergency Management hazards assessors will review appropriate documentation, perform a building walk down, and develop emergency action levels (EALs) for storage of LEU material. The EALs will be documented by a Field Change to EHA-70, "Emergency Management Hazards Assessment for the Materials and Fuels Complex (MFC)," and EPI-92, "MFC Operational Emergency Categorization/Classification and Protective Actions." No further emergency management action is required to complete turnover to operations. It is important to note that prior to movement of actual nuclear material into the building, approximately six months lead time is needed to perform the required Emergency Management analyses and generate additional emergency action 


Idaho National Laboratory
\begin{tabular}{|l|lll|}
\hline MATERIAL SECURITY AND & Identifier: & PLN-4173 & \\
CONSOLIDATION PROJECT & Revision: & 1 & \\
& Effective Date: & $10 / 11 / 2012$ & Page: 14 of 20 \\
\hline
\end{tabular}

levels (EALs) for nuclear material transportation and to evaluate impacts on other INTEC operations.

\section{AUTHORIZATION AND NOTUEICATION}

The Startup Authorization Authority (SAA), as identified in the approved Activity Description and Evaluation documentation, will follow the process defined in MCP-9902, Verification of Readiness to Start Up or Restart Nuclear Facilities, Section 4.5 Contractor Readiness Assessment. The SAA for this project is "an official of a level commensurate with the DSA Approval Authority", the DOE-ID Operations Office Manager.

\section{PROJECT ACCEPTANCE, BENEFICIAL OCCUPANCY, AND TRANSFER TO OPERATIONS}

Project acceptance and transfer to operations will be completed as specified in the checklist provided in Appendix B.

\section{BUSINESS FUNCTIONS}

\subsection{Disposition Materials}

All government-furnished equipment provided to project contractors was installed by the construction subcontractor into the applicable facility. Examples of government-fumished equipment include the criticality alarm system, security door in the CPP-651 vestibule, walk-behind pallet jack, and personal contamination monitor (PCM). No further action is required.

NOTE: The PM will make the determination that property items are no longer needed to support project objectives and can be disposed of as excess property. All assets purchased by either BEA or a subcontractor will be evaluated for excess disposal. For example, computers and monitors, salvageable materials, scrap materials, real property, residual materials from construction or installation efforts, etc., will be considered and evaluated. See LWP-2016, "Disposing of Government Personal Property, ${ }^{17}$ for additional disposal guidance.

\subsection{Project Transfer Form Distribution}

The distribution of the approved Form 432.04 is defined on the form and will include the property management director, the general accounting manager, the signers of the form, and the DOE-ID Federal Project Director. 


Idaho National Laboratory
\begin{tabular}{|l|lll|}
\hline MATERIAL SECURITY AND & Identifier: & PLN-4173 \\
CONSOLIDATION PROJECT & Revision: & 1 & \\
\hline
\end{tabular}

\section{PROJECT INFORMATION AND RECORDS TURNOVER}

Project information generated during turnover activities will be uploaded into EDMS and filed under the MSCP project number (30050) during final project closeout following CD-4 approval.

\section{TRANSITION TO OPERATIONS NOTIFICATION}

Transition to operations notification will be prepared by the nuclear facility manager following successful completion of the MSA and RA. This activity is in the MSCP scope.

\section{POST CRITICAL DECISION-4 ACTIVITIES}

The MSCP scope includes post CD-4 activities for final project closeout. CPP-651 operations following CD-4 approval is not in the MSCP scope.

\subsection{Complete Project Documentation}

The MSCP scope includes activities to complete as-built drawings generated from the subcontractor redlines, and place them into applicable BEA systems. Essential as-built drawings will be completed as part of CD-4 preparatory activities, with all other required as-built drawings completed during project close-out. Following incorporation of as-builts, and all other required activities including approval of $\mathrm{CD}-4$, the engineering job will be closed by the BEA engineering department. Preparation of the final project report and cost closing statements are part of the MSCP scope and performed during closeout. Post CD-4 activities were included in the project scope prior to direction to include these activities in the nuclear facility operations budget. See Appendix $\mathrm{C}$ for a complete list of project documentation to be completed following CD-4 activities.

\subsection{Support Department of Energy PARS II Reporting}

The PARS II reporting is accomplished by the DOE-ID Federal Project Director and is generated from the data supplied on the Monthly Project Sunmary Report. The project is already generating adequate performance information for the Federal Project Director to complete the PARS reporting.

\subsection{Prepare the Lessons Learn Document}

Lessons learned will be incorporated into the final project report that will be prepared during project closeout activities following approval of CD-4. Lessons learned will be generated by the project team during the post-project review. 


Idaho National Laboratory
\begin{tabular}{|l|lll|}
\hline MATERIAL SECURITY AND & Identifier: & PLN-4173 & \\
CONSOLIDATION PROJECT & Revision: & 1 & \\
& Effective Date: & $10 / 11 / 2012$ & Page: 16 of 20 \\
\hline
\end{tabular}

\subsection{Obtain Leadership in Energy and Environmental Design Certification}

This project does not meet the minimum program requirements for Leadership in Energy and Environmental Design (LEED) certification. This project is primerily a security upgrade to an existing facility: INTEC-651 the Unirradiated Storage Facility and the surrounding security perimeter. Modifications to the facility include the installation of perimeter security fence and security features, LEU handling equipment, new security door, and facility entry vestibule. INTEC-651 is not a fully occupied facility and has primary function of being a storage facility for muclear material. The equipment installed in the facility by the project do not constitute any facility energy management devices that would contribute to a LEED certification for the existing facility. The primary function of material storage and no continuous occupancy negate the needs for the certification.

\subsection{Notify 10-Year Site Plan of Project Status}

Once CPP-651 has been successfully transferred to operational status, the MSCP project manager will provide input to the 10 -year site plan of facility capabilities.

\subsection{Notify the Facility Information Management System}

Once CPP-651 has been successfully transferred to operational status, the MSCP project manager will update the facility information management system.

\section{APPENDIXES}

Appendix A, Checklist for Partial Project Transfer

Appendix B, Checklist for Final Project Transfer

Appendix C, Project Closeout Checklist 
Idaho National Laboratory

Foct 412.08 (Red 10)

MATERIAL SECURITY AND

Identifier: PLN-4173

Revision: 1

CONSOLIDATION PROJECT

Effective Date: $10 / 11 / 2012$

Page: 17 of 24

\section{Appendix A}

Checklist for Partial Project Transfer \#1

The following facility turnover checklists include the minimum activities required for partial and final facility transfer. Additional items may be added to the checklist if required by the Facility/System Tumover Review Committee.

Faicility/Systems: Vestibule including doors and interior finishes; Electrical power supply and delivery systems; Fencing and gates: CPP-651 exterior repairs: CPP-651 Fire Protection Piping System.

\section{Readiness Checklist for Partial Project Transfer \#1}

\begin{tabular}{|c|c|c|c|c|}
\hline \multirow{2}{*}{\multicolumn{2}{|c|}{ Deliverable or Activity }} & \multicolumn{3}{|c|}{ Completed? } \\
\hline & & \multirow{2}{*}{ Yes } & \multirow{2}{*}{ No } & \multirow{2}{*}{ N/A } \\
\hline 1. & Final inspection walkthrough. & & & \\
\hline 2. & $\begin{array}{l}\text { Punch list items on Form 423.68, "Project Deficiency Status } \\
\text { Report." }\end{array}$ & $\mathrm{x}$ & & \\
\hline 3. & $\begin{array}{l}\text { List of deficiencies to be corrected and remaining activities } \\
\text { before and after partial project transfer as listed on Form } 423.04 \text {, } \\
\text { "Inspection and Project Transfer." }\end{array}$ & $\mathrm{X}$ & & \\
\hline 4. & Relevant system inspections completed. & $x$ & & \\
\hline
\end{tabular}

Appendix A 
432.04

$08 / 30 / 2005$

INSPECTION AND PROJECT TRANSFER

Page 1 of 3

Rev. OS

\begin{tabular}{|c|c|c|}
\hline & $\underset{30050}{\stackrel{\otimes}{\square}}$ & $\begin{array}{l}\text { Partial } \\
\text { Final } \\
\text { Project Nurnber }\end{array}$ \\
\hline TION & & \\
\hline
\end{tabular}

PROJECT TITLE; Material Securily Consolldalion Project (MSCP)

Paktial Tramsfaer H

as constructed by

C\&H Construction, Inc

(Name of Subcontractor or Direct filre)

119824

Subcontraci No.

The projact (or portion of the project) was found by the Project Team (signalures as shown below) to be complele in accordance with the contractual documenls excepi for such deficiencies specifically noled below. The project (or portion of the project) is ready for.tesling and start-up activities.

Deficiencies (allach list if necessary):

See Project Deficiciency Status Report (form 432.68)

Comments:

This Parlial Project Transier Includes:

1.) Vestibule including doors and interior finishes

2.) Eleclrical power supply and delivery systems

3.) Fencing and gales

4.) CPP.G5'l exterior repalss

5.) CPP-651 Fire Protection Piping System

PROJEGT TEAM APPROVAL

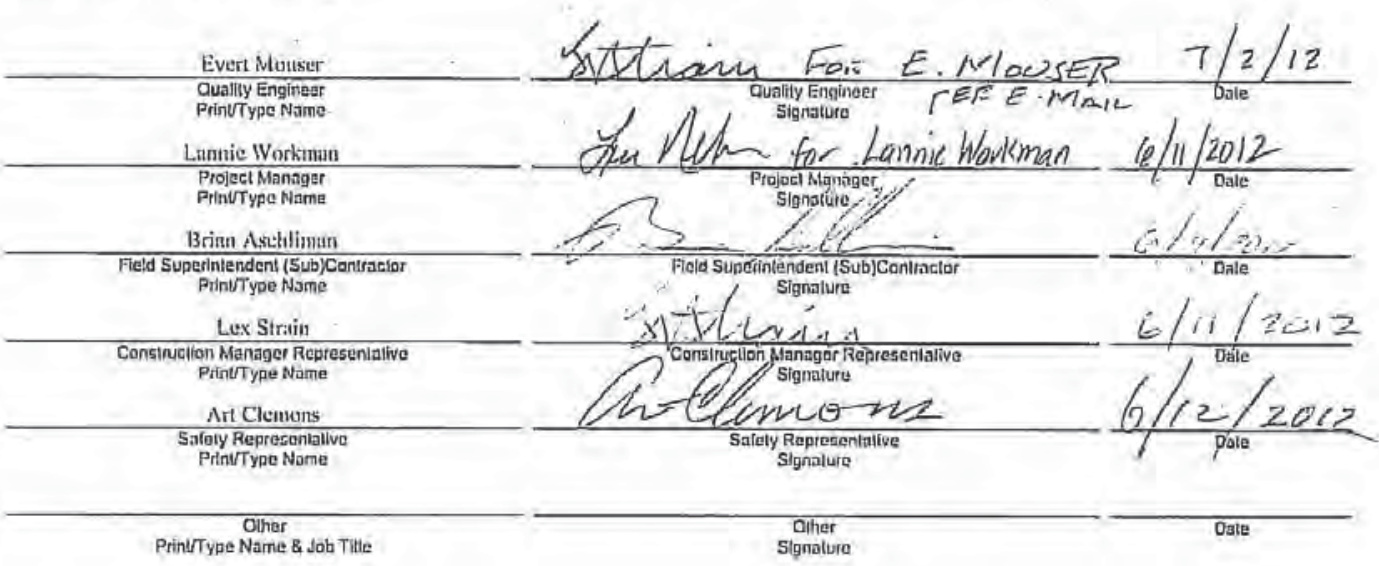




\section{PARTIAL PROJECT TRANSFER TO FACILITY MANAGER}

I certify that our personnel have monitored the design, fabrication, and installation of the project (or portion of the project) and, to the best of my knowledge, the work has been completed in accordance with the plans and technical specificalions, including all approved changes. The project (or portion of the project) is hereby ready to be tumed over to the Facility Manager for system operational testing and other activilies in preparation for final project transfer.

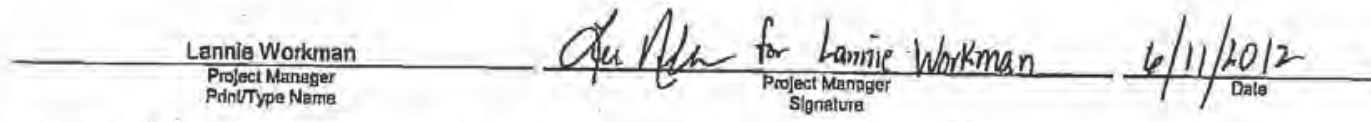
MScC Signature

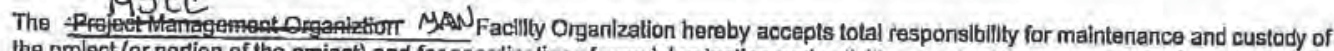
the project (ar portion of the project) and for coordination of remalning testing and activities required to prepare for final project transfer.

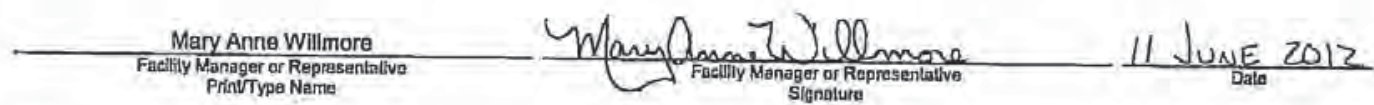

\section{INTERIM DISTRIBUTION}

Signatories, Land/Facllity Operallons, and Project File. For capital-funded projects include Property Accounting and Property Management.

WORK COMPLETION

\section{SUBGONTRACTOR/DIRECT HIRE:}

I certify on behalf of C\&H Construclion, Inc.

subject to the penalties provided under 18 U.S.C, Section 1001, that our personnel have accompllshed the contract work and, to the best of my knowledge, the work was performed or accomplished in accordance with the contraclual documents, including all approved changes.

Clayne Hanson
$\begin{gathered}\text { Subcontractar Aulhorized Fepresentalive } \\ \text { Prinu/Type Name }\end{gathered}$

1 certify that the administrallon of the contract for the above named project Is, to the best of my knowledge, complete to the extent required for this Project Transfer and/or close out of the contract 
I certify completion of final testing and project review to ensure project requirements have been met in accordance wilh the Tumover and Acceptance Plan. The project (or portion of the project) lo hereby ready lo be tumed over to the Facility Manager for acceplance.

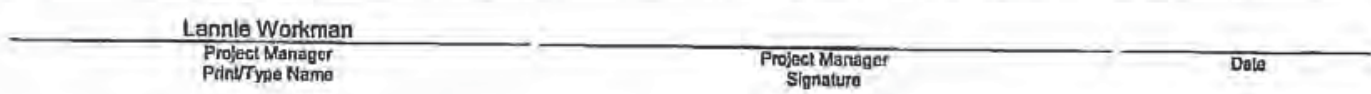

The project (or portion of the project) is hereby accepted for the Government.

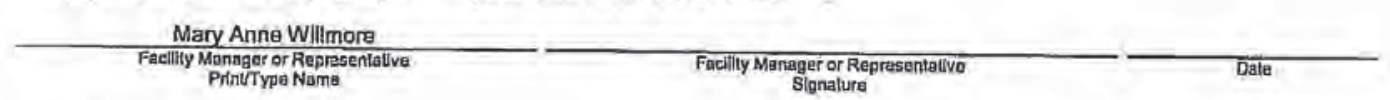

\section{FINAL DISTRIBUTION}

Signatories, plus DOE-ID Project Manager, Project File, and Land/Faclity Operations. For capital-funded projects, include Property Accounting, Property Management, and Financial Construction Coordinalor.

\section{INSTRUCTIONS}

In accordance with MCP-2869, "Project Tumover and Acceptance," thls form documents the final inspection between the subcontractorl direct hire and the Facillty Manager, and effects partial and final transfers of the project (or portion of the project) to the Factilty Manager.

\section{INSPECTION}

1. The "Inspection" sectlon is to be used for both partlal and final project transfers. In general, a partial project transfer occurs when the contract ar a specific and defineble portion of the project has been completed and is to be turned over to the Facility Manager for custody and maintenance. Items such as SO Testing, Life Safety System lie-Ins, teminalions, and final project documentalion still remain to be accomplished.

2. The description needs to be detailed and clear on what is being transferred (e.g., reference drawing list, equipment list).

3. Defictencies should oniy be allowed for partial transfers. If possible, Include planned completion dale for each deficiency. 4. Quality Englneer signs for quality slgnificant projects, Fleld Engineer signs for Consumer Grade projects, or bolh sign for projects
that are combined activilies.

\section{PARTIAL PROJECT TRANSFER APPROVAL}

1. The "Partial Project Transfer to Facility Manager" section is to be filled out for partial project transfer of the project (or portion of the project) from the subcontractor/direct hire to the Facility Manager after review by the Project Tumaver Revjew Committes demonstrates that the project (or portion of tha project) is safe and ready for occupancy and SO Testing activitles.

\section{WORK COMPLETION}

1. The Work Completion" section is to be filled out to certify contract work is complete. This is to be done in canjunction with the Final Project Transfer.

\section{FINAL PROJEGT TRANSFER APPROVAL.}

1. The "Final Project Transfer" section is to be filled out after final testing (such as SO testing), completion of all remaining project actuviles, and review by the Project Tumover Reviaw Committee demonstrate that the project (or portion of the project) is ready for acceptance by the Facility Manager/user organization.

2. Use of this form does not constlute start-up approval of the project or portion thereof. 


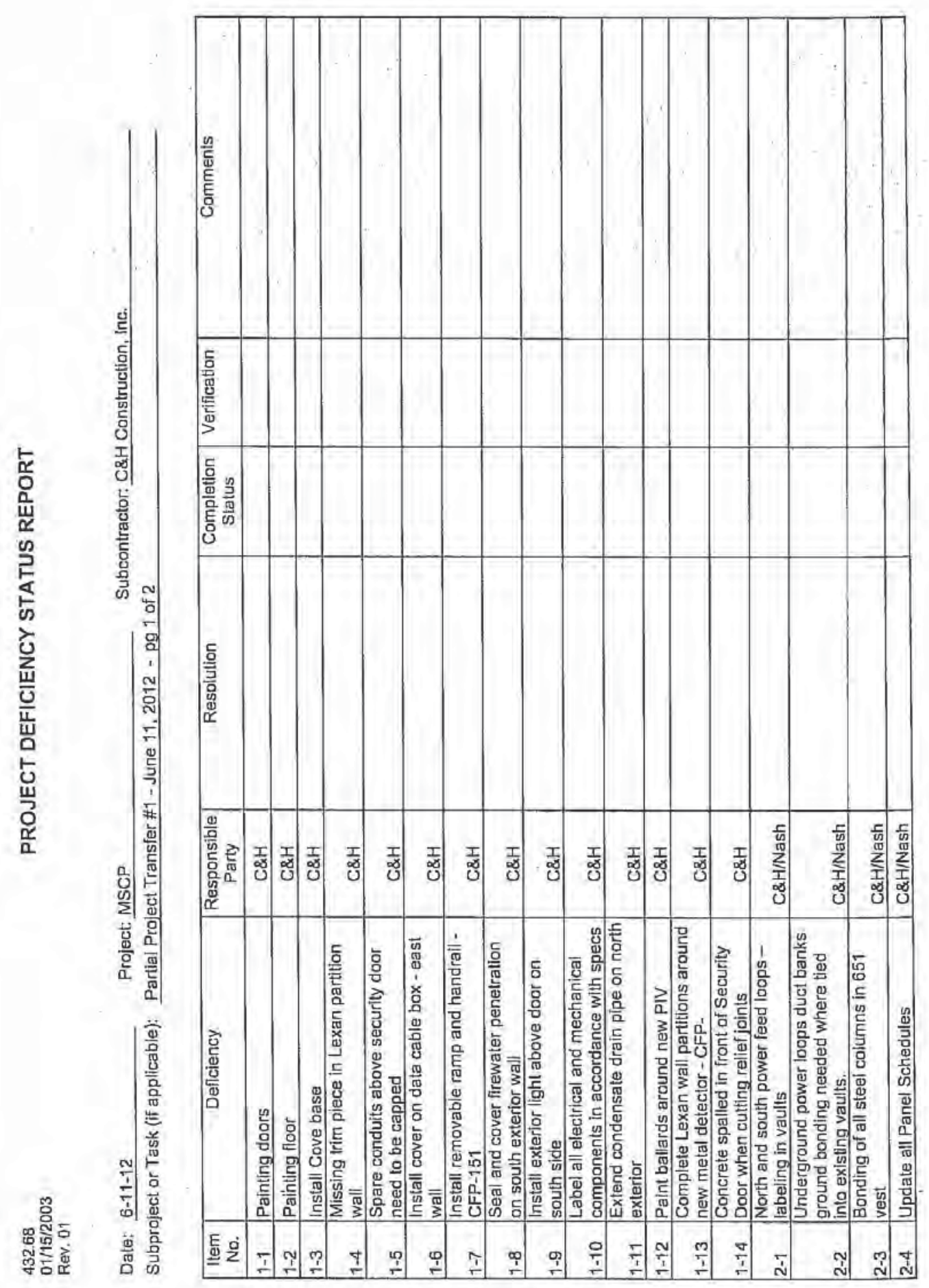




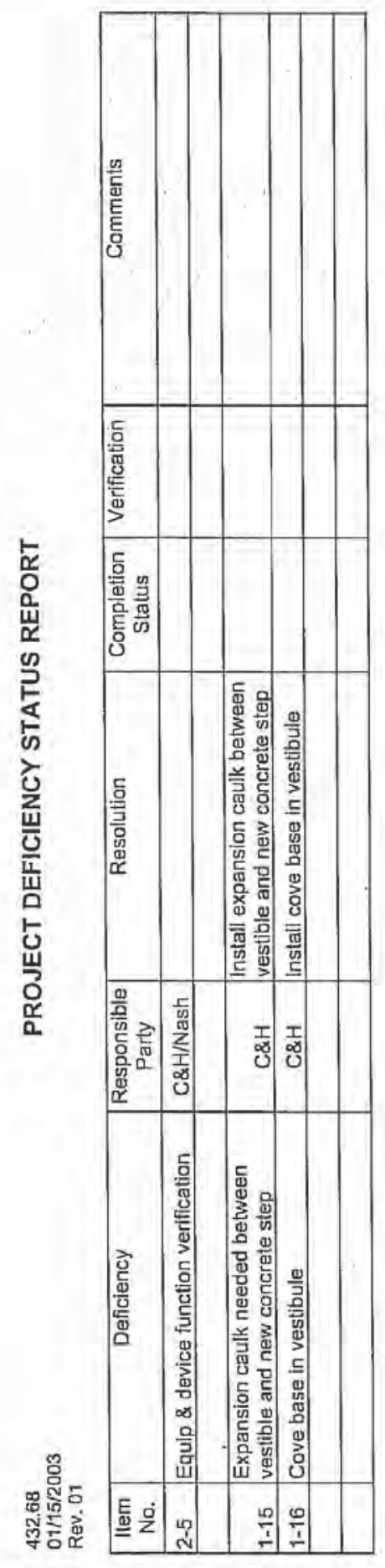




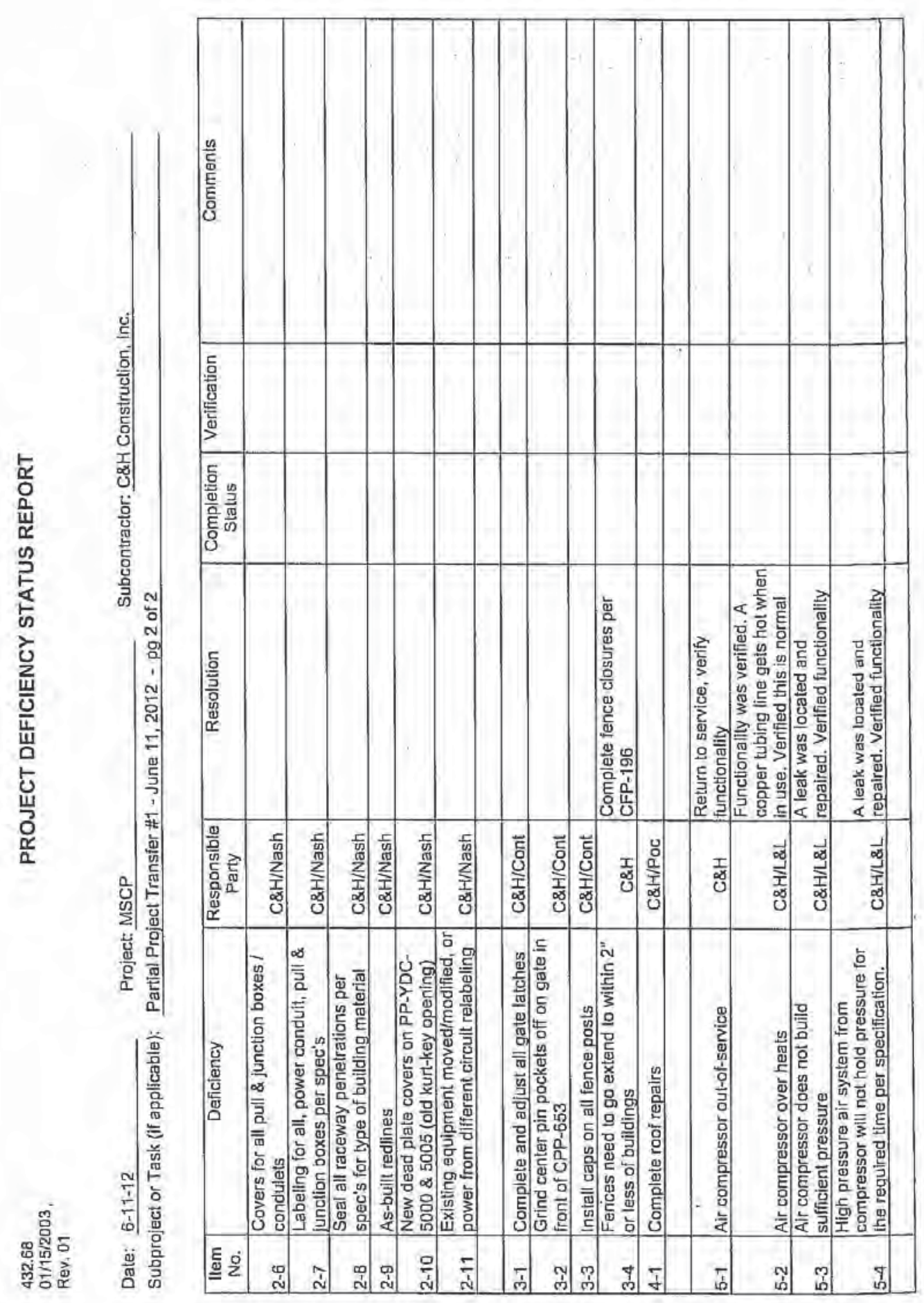




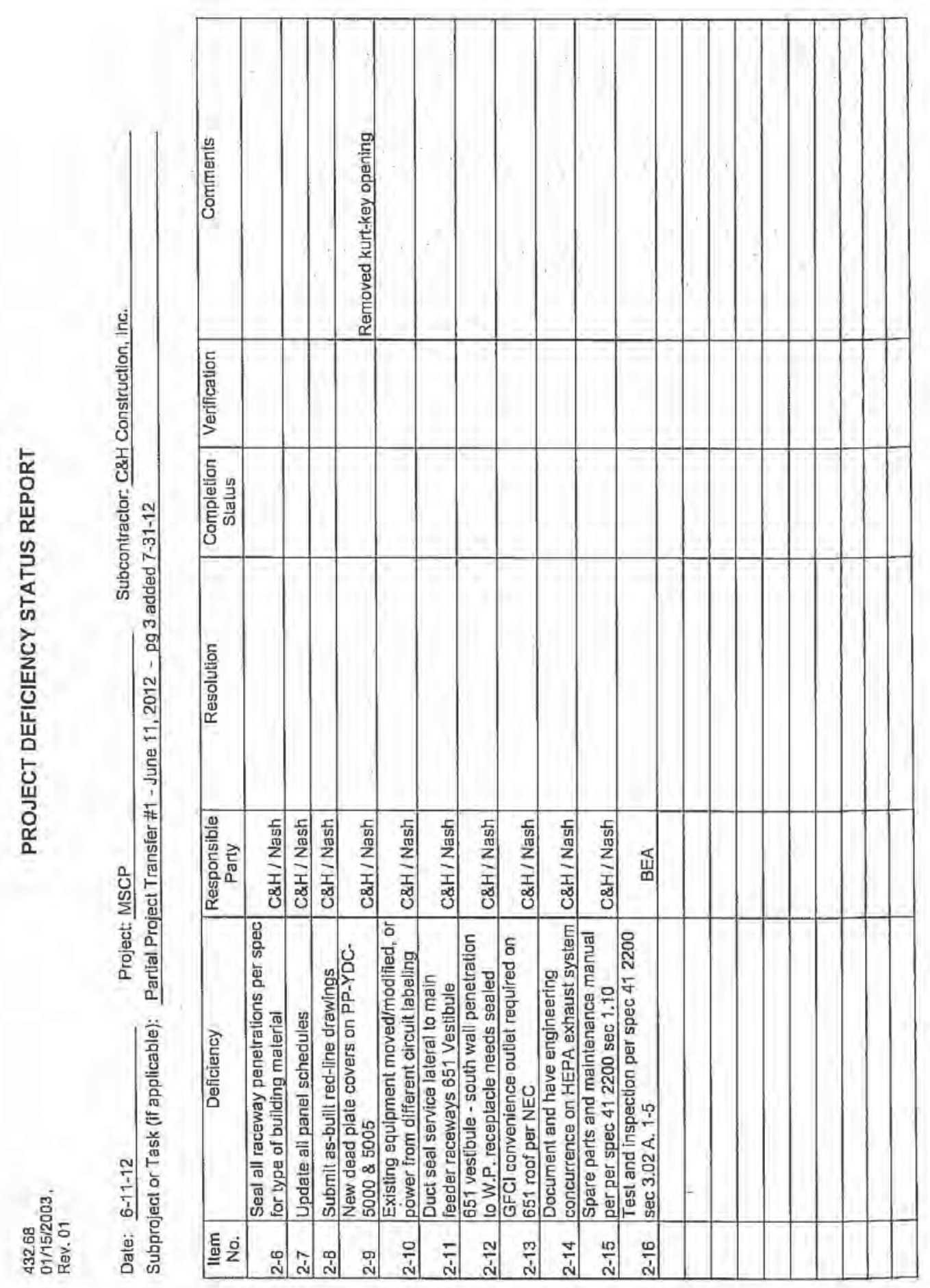




\begin{tabular}{|lll|}
\hline Identifier: & PLN -4173 & \\
Revision: & 1 & \\
Effective Date: & $10 / 11 / 2012$ & Page: 18 or 24 \\
\hline
\end{tabular}

\section{Appendix A}

\section{Checklist for Partial Project Transfer \#2}

The following facility turnover checklists include the minimum activities required for partial and final facility transfer. Additional items may be added to the checklist if required by the Facility/System Tumover Review Committee.

Facility/Systems: Security Systems: Telecommunications Systems: Overhead Bridge Crane in North Vault: Storage Racks in North Vault.

\section{Readiness Checklist for Partial Project Transfer \#2}

\begin{tabular}{|l|l|l|l|l|}
\hline \multicolumn{2}{|c|}{ Deliverable or Activity } & \multicolumn{3}{c|}{ Completed? } \\
\cline { 3 - 5 } 1. & Final inspection walkthrough." & Yes & No & N/A \\
\hline 2. & $\begin{array}{l}\text { Punch list items on Form 423.68, "Project Deficiency Status } \\
\text { Report." }\end{array}$ & $\mathrm{X}$ & & \\
\hline 3. & $\begin{array}{l}\text { List of deficiencies to be corrected and remaining activities } \\
\text { before and after partial project transfer as listed on Form 423.04, } \\
\text { "Inspection and Project Transfer." }\end{array}$ & $\mathrm{X}$ & & \\
\hline 4. & \begin{tabular}{l} 
Releyant system inspections completed. \\
\hline
\end{tabular} & $\mathrm{X}$ & & \\
\hline a. & The walkthrough ensures that all physical work required by the subcontract is substantially complete. \\
\hline
\end{tabular}

Appendix A 
INSPECTION

PROJECT TITLE: Malerial Security Consolidalion ProjecL (MSCP)

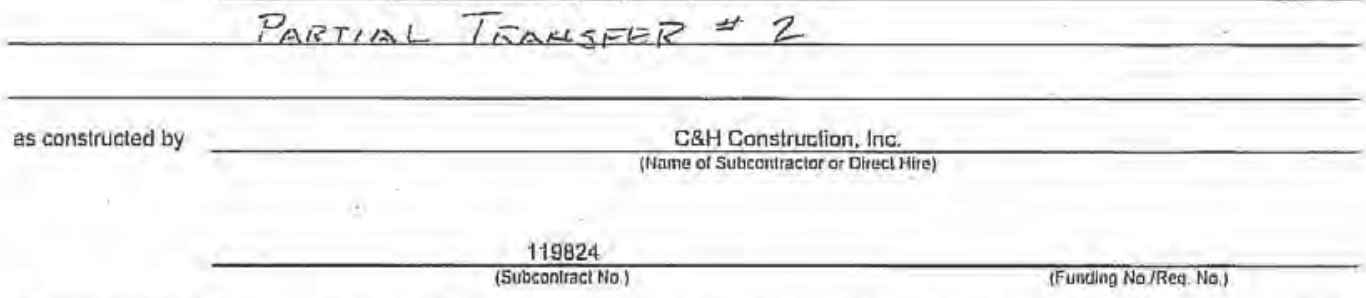

The project (or portion of the projecl) was lound by the Projecl Team (signalures as shown below) to be complele in accordance wilh the contractual documents except for such deficiencies specifically noled below. The project (or portion of the project) is ready for lesling and slart-up activilies.

Deficiencies (allach list if necessary)

See Project Deficiciency Slalus Report (form 432,68)

Comments:

This Partial Project Transfer ( $(\hbar 2)$ Includes:

1.) Securily Syslems, including alarm wiring, door control wiring, melal delector and SNM Deleclar

2.) Telecammunications Systems

3.) Overhead Bridge Crane in North Vaull

4.) Storage Racks in North Vault

PROJECT TEAM APPROVAL

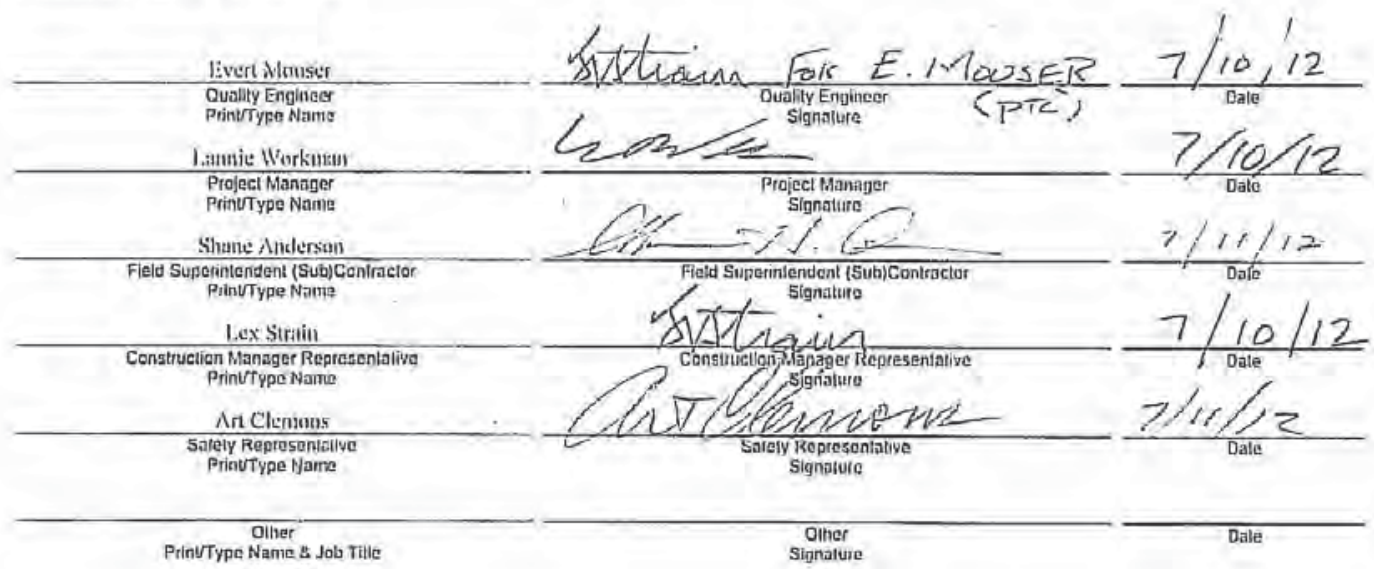




\section{PARTIAL PROJECT TRANSFER TO FACILITY MANAGER}

I cerlify that our personnel have monitored the design, fabricalion, and installation of the project (or portlon of the project) and, to the best of my knowledge, the work has been completed in accordance with the plans and technical specifications, including all approved changes. The project (or portion of the project) is hereby ready to be turned over to the Facility Manager for system operational testing and olher activities in preparation for final project transfer.

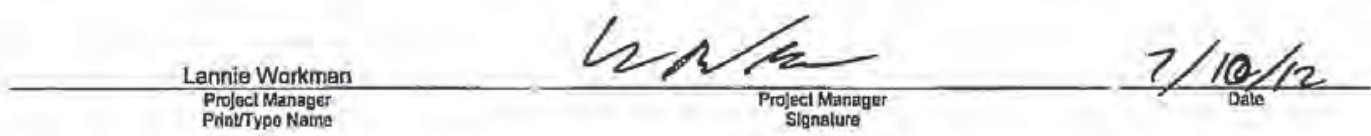

The Project Management Organiztion_ Facility Organization heraby accepls total responsibility for maintenance and custody of the project (or portion of the project) and for coordination of remaining lesting and aclivities required to prepare for final project transfer.

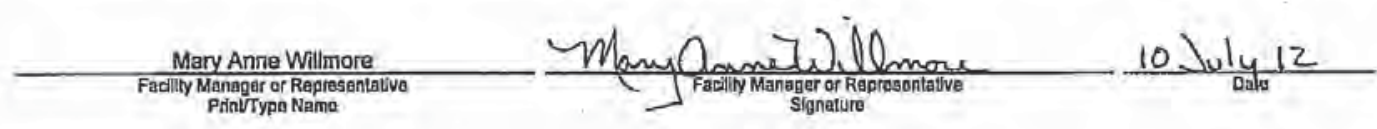

\section{INTERIM DISTRIBUTION}

Signateries, Land/Facillty Operattons, and Project File. For capital-funded projects include Property Accounting and Property Management.

\section{WORK COMPLETION}

\section{SUBCONTRACTORIDIRECT HIRE:}

I cerlify an behalf of $\mathrm{G} \& \mathrm{H}$ Consiruction. Inc.

subject to the penallies provided under 18 U.S.C., Section 1001, that our personnel have accomplished the contract work and, to the best of my knowledge, the work was performed or accornplished ln accordance with the contractual documents, including all approved changes.

\begin{tabular}{l} 
Clayne Hanson \\
\hline $\begin{array}{c}\text { Subconlraclor Authorized Representalivo } \\
\text { Print/Typo Name }\end{array}-\begin{array}{c}\text { Subconlactor Authorized Rapresentalive } \\
\text { Signature }\end{array}$
\end{tabular}

I certify that the administration of the contract for the above named project is, to the best of my knowledge, complele to the extent required for this Project Transfer and/or close out of the conlract

Troy Lark
Procutement Agant / Construetion Manager Representalivo
Printrypo Nams


1 certify completton of final lesting and project review to ensure project requirements have been met in accordance with the Turnover and Acceplance Plan. The project (or portion of the project) is hereby ready to be tumed over to the Facility Manager for acceptance.

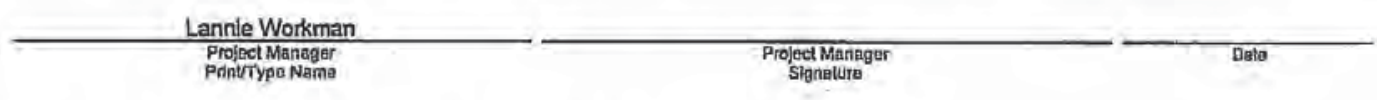

The project (or portion of the project) is hereby accepted for the Government.

Mary Anne Willmore
$\begin{gathered}\text { Facility Manager or Rapresenta tive } \\ \text { PrinvType Name }\end{gathered}$

\section{FINAL DISTRIBUTION}

Signalories, plus DOE-ID Project Manager, Project File, and LandiFacillty Operallons. For capilal-funded projects, include Property Accounting, Property Management, and Financial Construction Coordinalor.

\section{INSTRUCTIONS}

In accordance with MCP-2869, "Project Turnover and Acceplance," Ihis form documents the final Inspection between the subcontractor/ direct hirs and the Facility Maniager, and effects partial and final transfers of the project (or portion of the project) to the Facility Manager.

\section{INSPECTION}

1. The "Inspection" section is to be used for both partial and final project transfers. In general, a partial project transfer occurs when the contract or a specific and definable portion of the project has been completed and is to be tumed over to the Facility Manager for custody and mainlenance. Ilems such as SO Testing, Life Safety System tie-lins, teminalions, and final project documentation still remain to be accomplished.

2. The description needs to be delalled and clear on what is being transferred (e.g., reference drawing list, equipment list).

3. Deficiencies should only be allowed for partial transfers. If possible, include planned completion dale for each deficiency.

4. Quality Engineer signs for quality signilicant projects, Field Engineer signs for Consumer Grade projects, or both sign for projects that are combined aclivilles.

\section{PARTIAL PROJECT TRANSFER APPROVAL}

1. The "Partial Project Transfer to Facility Manager" section is to be filled out for partial project transfer of the project (or portion of the project) from the subcontractor/direct hire to the Facility Manager afler revlew by the Project Tumover Review Commitlee demonstrates that the project (or portion of the project) is safe and ready for occupancy and SO Testing aclivities.

\section{WORK COMPLETION}

1. The "Work Completion" section is to be filled out to certify contract work is complete. This is to be done in conjunction with the Final Project Transfer.

\section{FINAL PROJECT TRANSFER APPROVAL}

1. The "Final Project Transfer" section is to be filled out after final testing (such as So tesling), campletion of all remaining project activities, and review by the Projed Tumover Review Commiltee demonstrate that the project (or portion of the project) is ready for acceptance by the Facility Manager/user organization.

2. Use of this form does not conslitule slart-up approval of the project or portion thereof. 


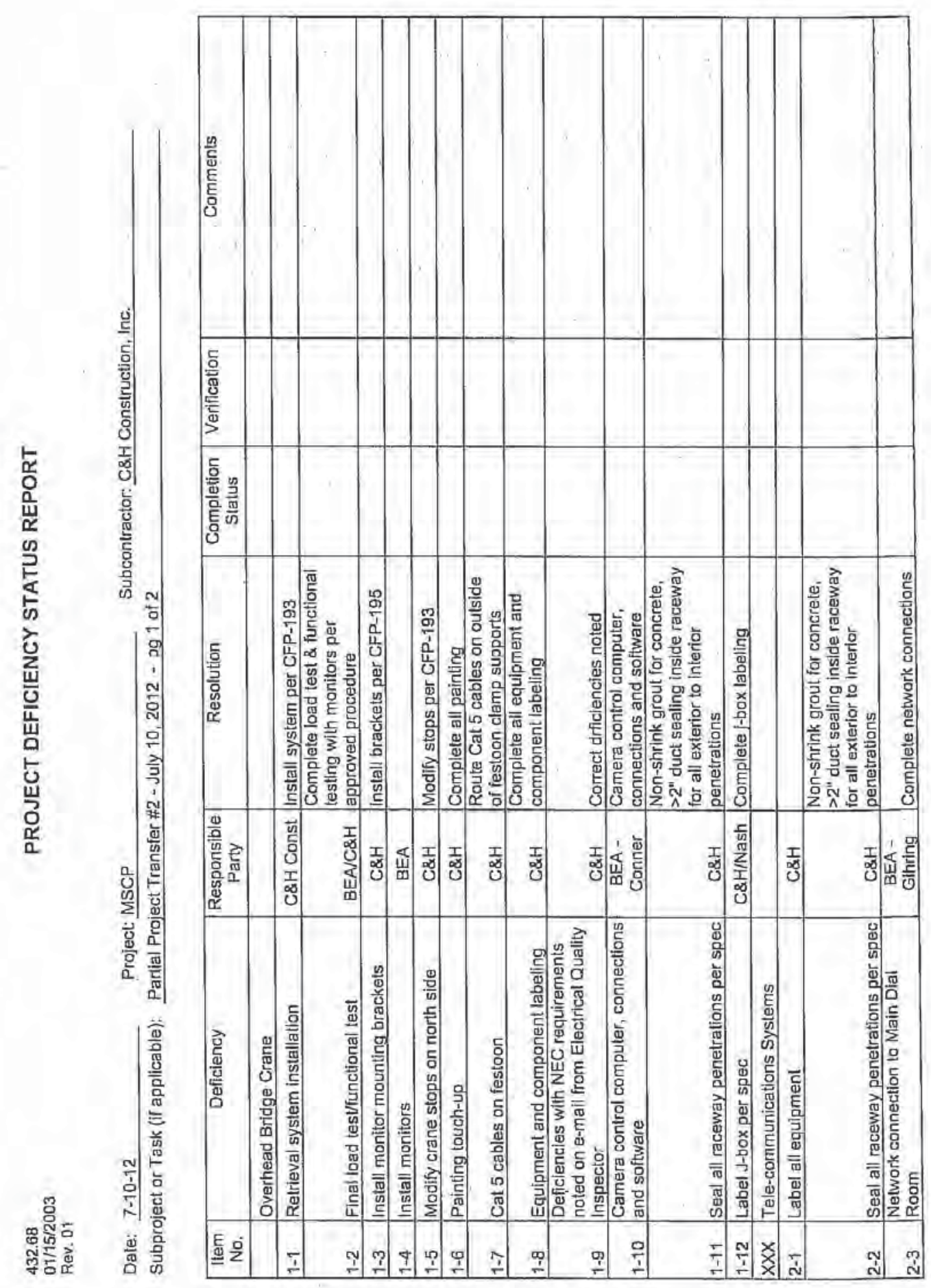




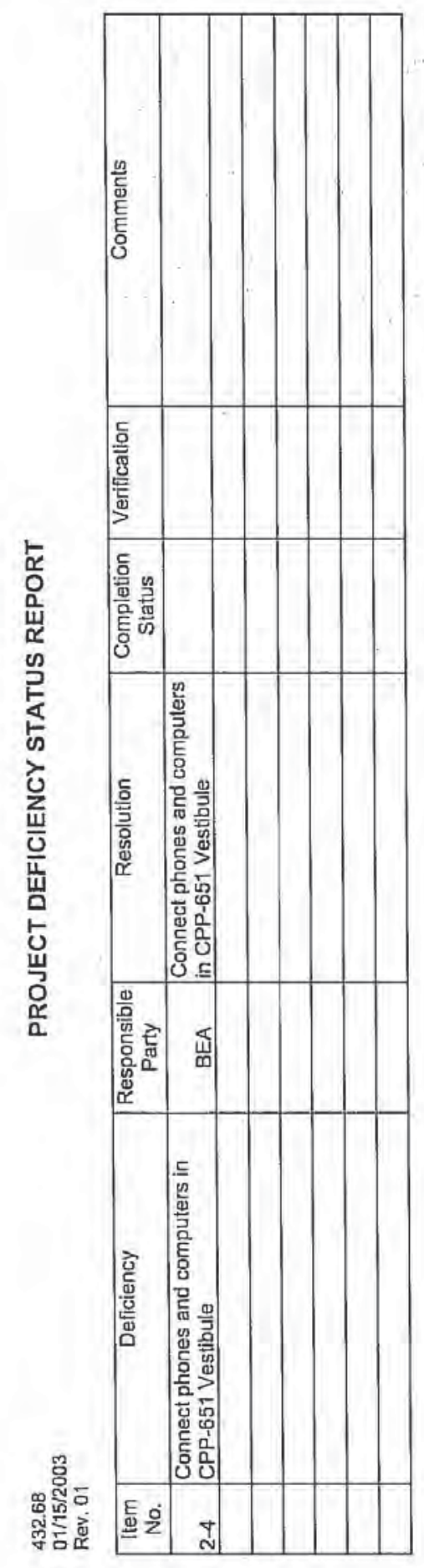




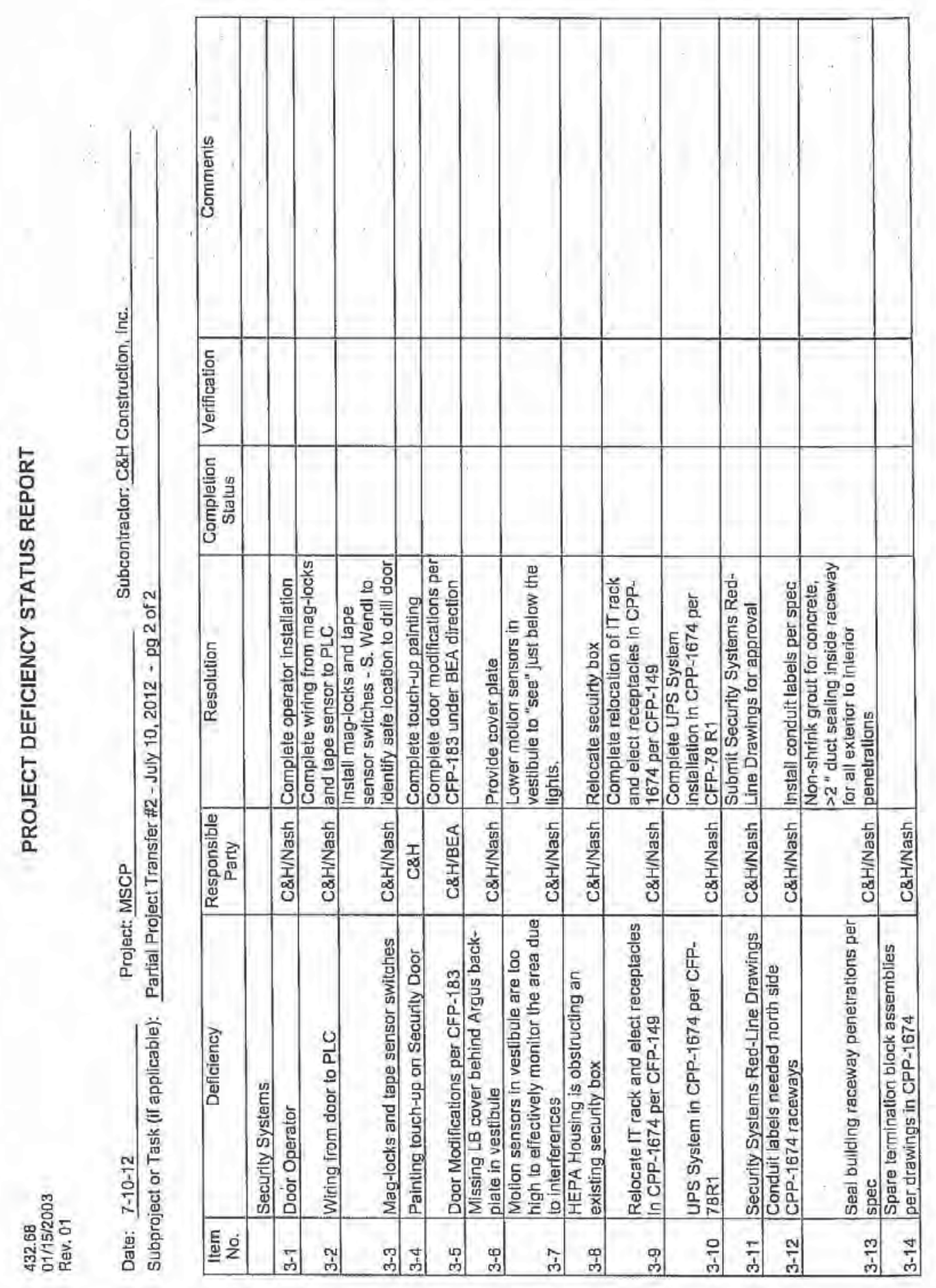




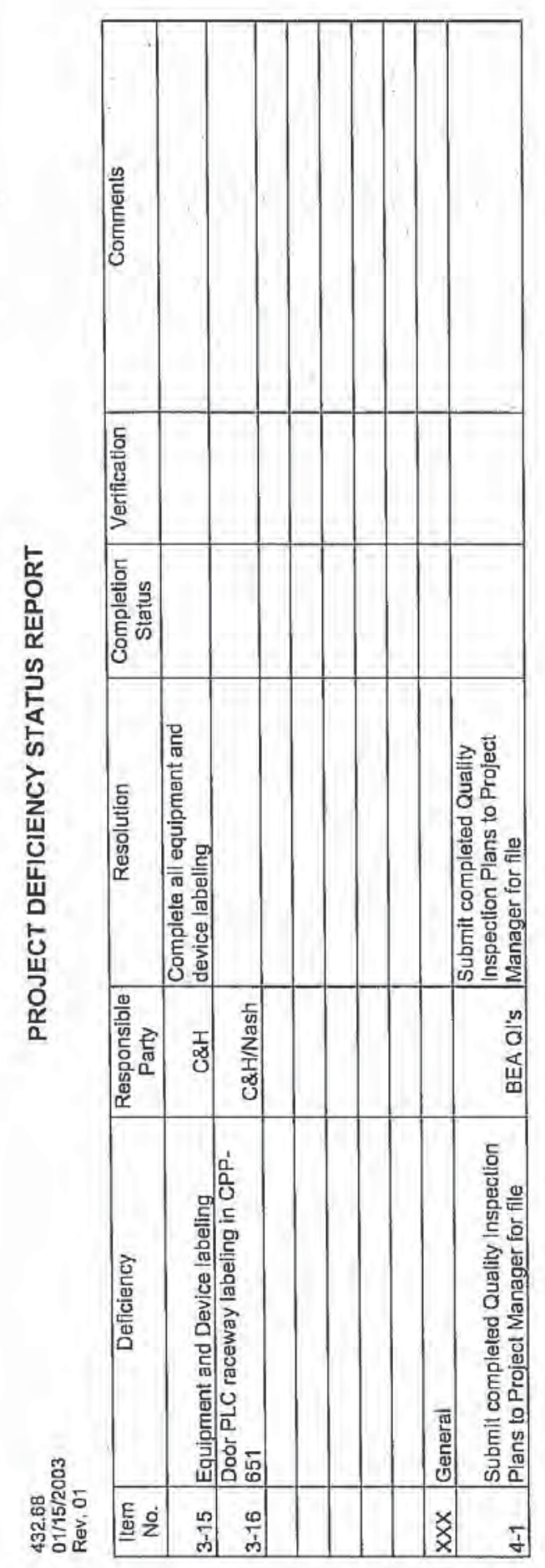


Appendix A

\section{Checklist for Partial Project Transfer \#3}

The following facility tumover checklists include the minimum activities required for partial and final facility transfer. Additional items may be added to the checklist if required by the Facility/System Turnover Review Committee.

Facility/Systems: HVAC Sytems.

\section{Readiness Checklist for Partial Project Transfer \#3}

\begin{tabular}{|l|l|l|l|l|}
\hline \multicolumn{2}{|c|}{ Deliverable or Activity } & \multicolumn{3}{c|}{ Completed? } \\
\cline { 3 - 5 } 1. & Final inspection walkthrough." & Yes & No & N/A \\
\hline 2. & $\begin{array}{l}\text { Punch list items on Form 423.68, "Project Deficiency Status } \\
\text { Report." }\end{array}$ & $\mathrm{X}$ & & \\
\hline 3. & $\begin{array}{l}\text { List of deficiencies to be corrected and remaining activities } \\
\text { before and after partial project transfer as listed on Form 423.04, } \\
\text { "Inspection and Project Transfer." }\end{array}$ & $\mathrm{X}$ & & \\
\hline 4. & \begin{tabular}{l} 
Relevant system inspections completed. \\
\hline
\end{tabular} & $\mathrm{X}$ & & \\
\hline & The walkthrough ensures that all physical work required by the subcontract is sibstantially complete. \\
\hline
\end{tabular}

Appendix A 


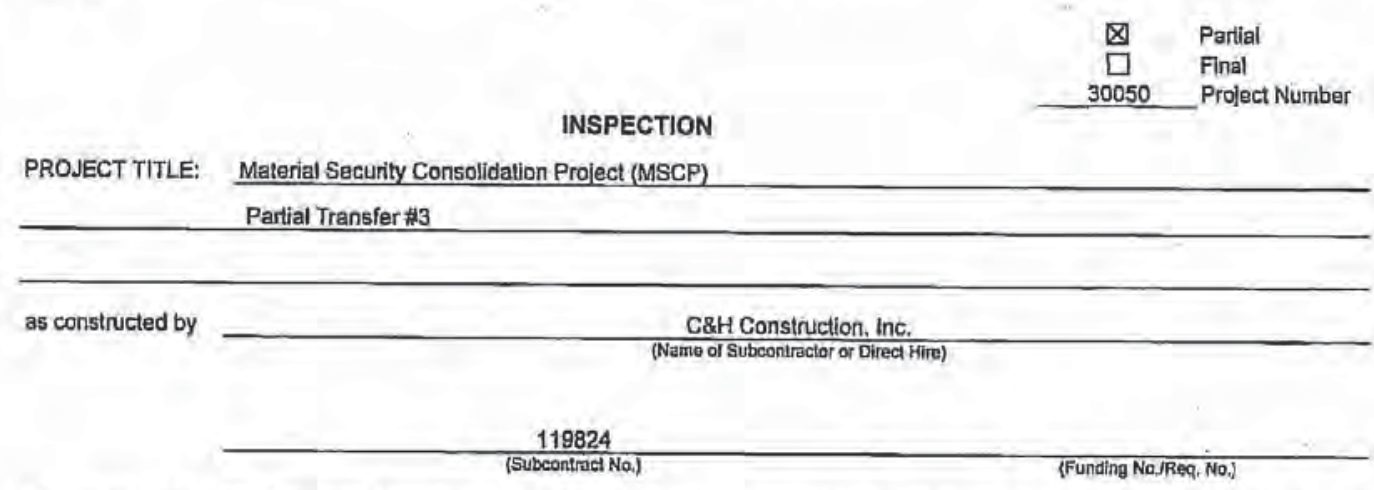

The project (or portion of the project) was found by the Project Team (signatures as shown below) to be complete in accordance wilh the contractual documents except for such deficiencles specifically noled below. The project (or portion of the project) is ready for testing and start-up activities.

Deficiencies (attach list if necessary):

See Project Deficiciency Stalus Report (form 432.68)

Comments:

Thls Partlal Project Transfer (*3) Includes:

1.) HVAC Systems

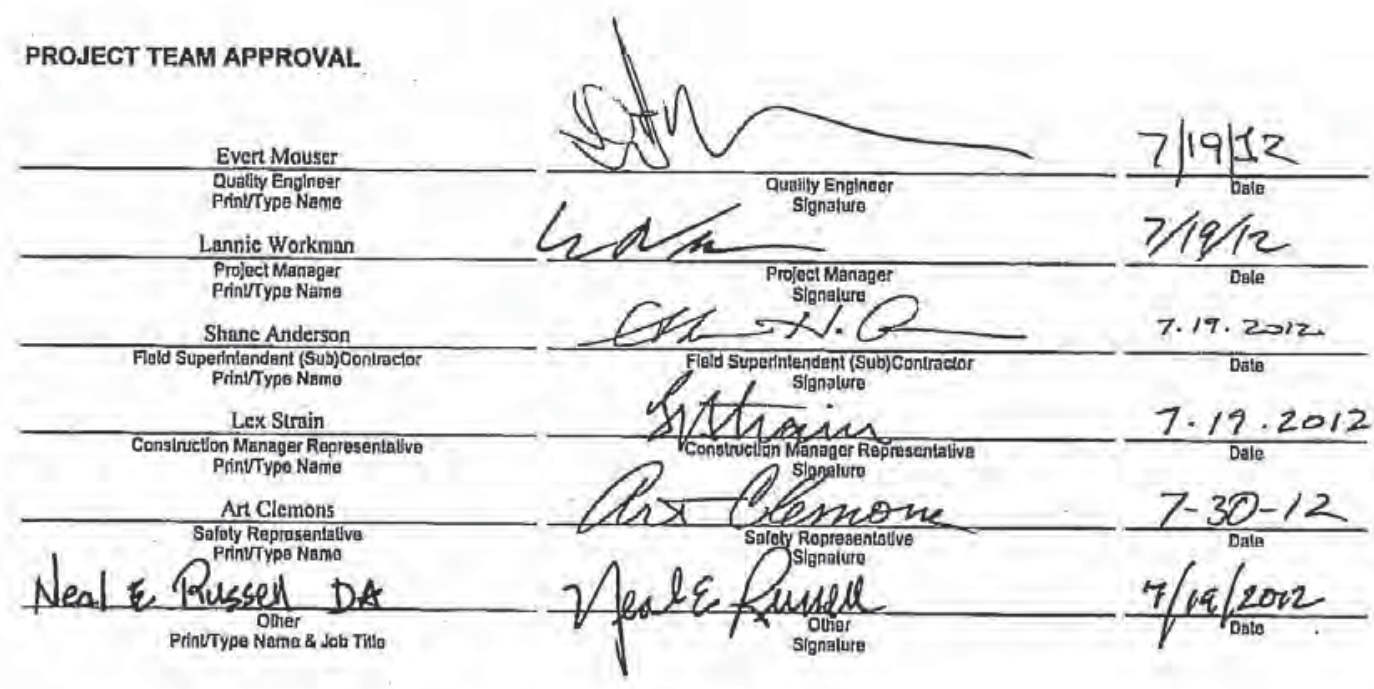




\section{PARTIAL PROJECT TRANSFER TO FACILITY MANAGER}

I certify that our personnel have monitored the design, fabrication, and installation of the project (or partion of the project) and, to the best of my knowledge, the work has been completed in accordance with the plans and technical specifications, including all approved changes. The project (or portion of the project) is hereby ready to be lumed over to the Faclity Manager for system operational testing and other activities in preparation for final project transfer.

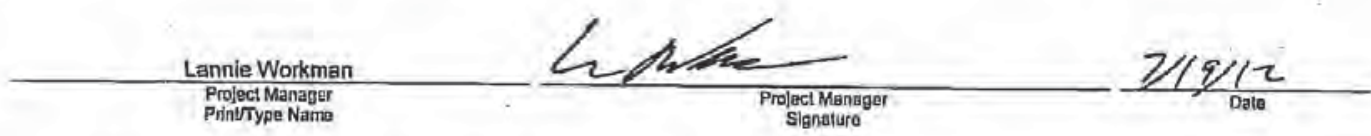

The Project Management Organiztion_Facility Organizatian hereby accepls total responsibility for maintenance and cuslody of the project (or portion of the project) and for coordination of remaining testing and activilies requirad to prepare for final project transfer.

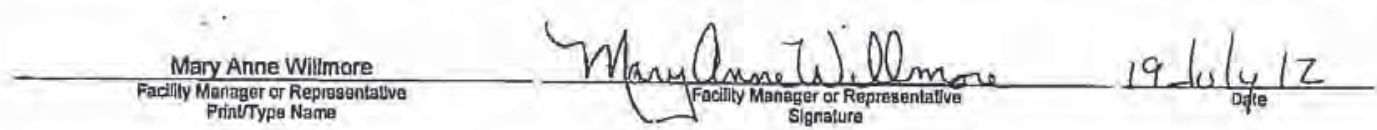

\section{INTERIM DISTRIBUTION}

Signatories, Land/Facility Operalions, and Project File. For capltal-funded projecls include Property Accounling and Property Management.

\section{WORK COMPLETION}

\section{SUBCONTRACTOR/DIRECT HIRE:}

I certify on behalf of C\&H Consinuction, inc.

subject to the penalties provided under 18 U.S.C., Section 1001, that our personnel have accomplished the contract work and, to the best of my knowledge, the work was performed or accomplished in accordance with the contractual documents, including all approved changes.

Clayne Hanson

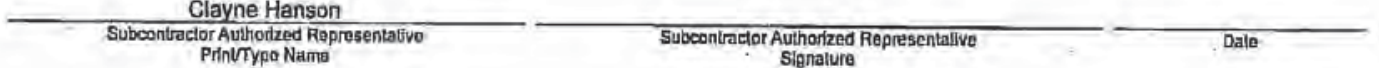

I certify that the administration of the contract for the above named project is, to the best of my knowledge, complete lo the extent required for this Project Transfer and/or close out of the contract

Procirement Agent/Cansiruetion Manager Roprosentaltve
PdntrType Name


I certify completion of final festing and project review to ensure project requirements have been met in accordance with the Turnover and Acceptance Plan. The project (or portion of the project) is hereby ready to be lurned over to the Facilly Manager for acceptance.

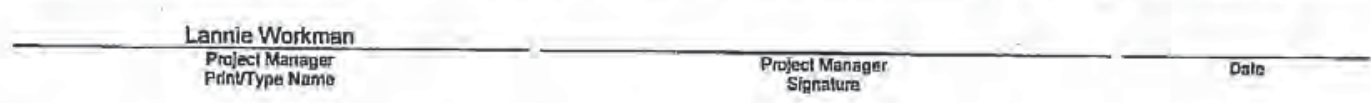

The project (or portion of the project) is hereby accepted for the Government.

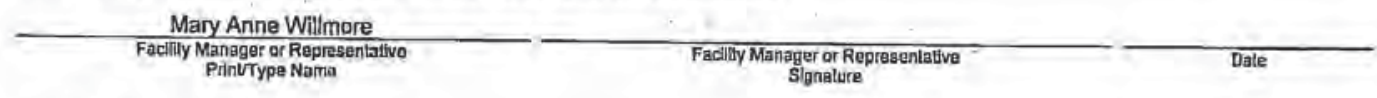

\section{FINAL DISTRIBUTION}

Signetories, plus DOE-ID Project Manager, Project File, and Land/Facility Operalions. For capital-funded projects, Include Property Accounting, Property Management, and Financial Construction Coordinator.

\section{INSTRUCTIONS}

In accordance with MCP-2869, "Project Tumover and Acceplance," this form documents the final Inspection between the subcontractorl direct hire and the Facillty Manager, and effects parlial and final transfers of the project (or portion of the project) to the Facillity Manager. INSPECTION

1. The "Inspection" section is to be used for both partial and final project transfers. In general, a partial project transfer occurs when the contract or a specific and definable portion of the project has been completed and is to be tumed over to the Facility Manager for custody and maintenance. Items such as SO Testing, Life Safety System tie-ins, terminations, and final project documentation still
remain to be accomplished.

2. The description needs to be detailed and clear on what is being transferred (e.g., reference drawing list, equipment list).

3. Deficiencies should only be allowed for partial transiers. If possible, include planned completion date for each deficiency.

4. Quality Engineer signs for quality significant projects, Field Engineer signs for Consumer Grade projects, or both sign for projects Ihat are combined activities.

\section{PARTIAL PROJECT TRANSFER APPROVAL}

1. The "Partial Project Transfer to Facility Manager" section is to be filled out for partial project transfer of the project (or portion of the project) from the subcontractor/direct hire to the Facility Manager after review by the Project Turnover Review Commitlee demonstrates that the project (or porlion of the project) is safe and ready for occupancy and SO Testing activilies.

\section{WORK COMPLETION}

1. The "Work Completion" section is to be filled out to certify contract work is complete. This is to be done in conjunction with the Fina Project Transfer.

\section{FINAL PROJECT TRANSFER APPROVAL}

1. The "Final Project Transfer" section is to be filled out afier final testing (such as So tesling), complellon of all remaining project activilles, and review by the Project Tumover Review Committee demonsirate that the project (or portion of the project) is ready for acceplance by the Faclity Manager/user organizallon.

2. Use of this form does not constitute start-up approval of the project or portion thereof. 


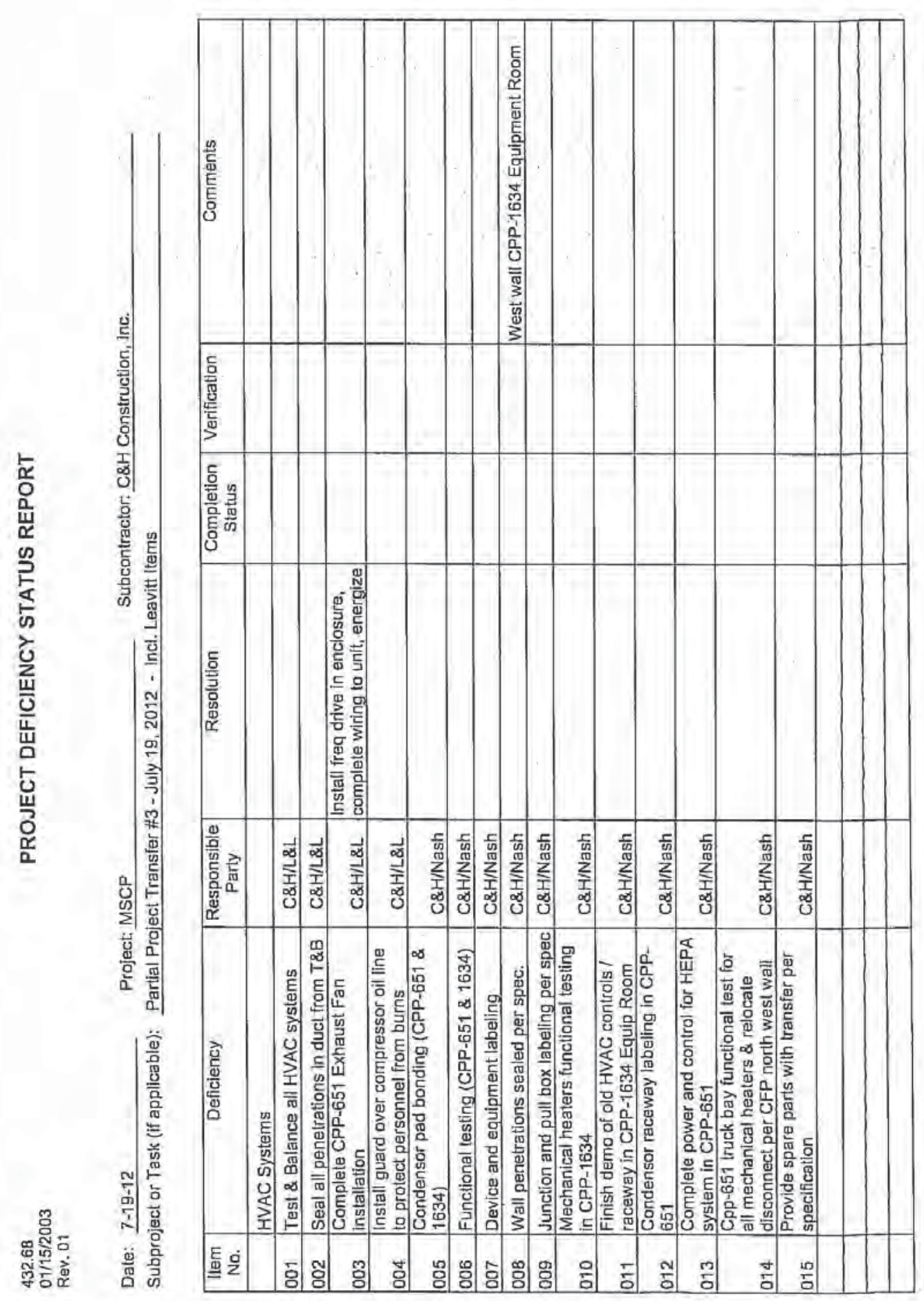




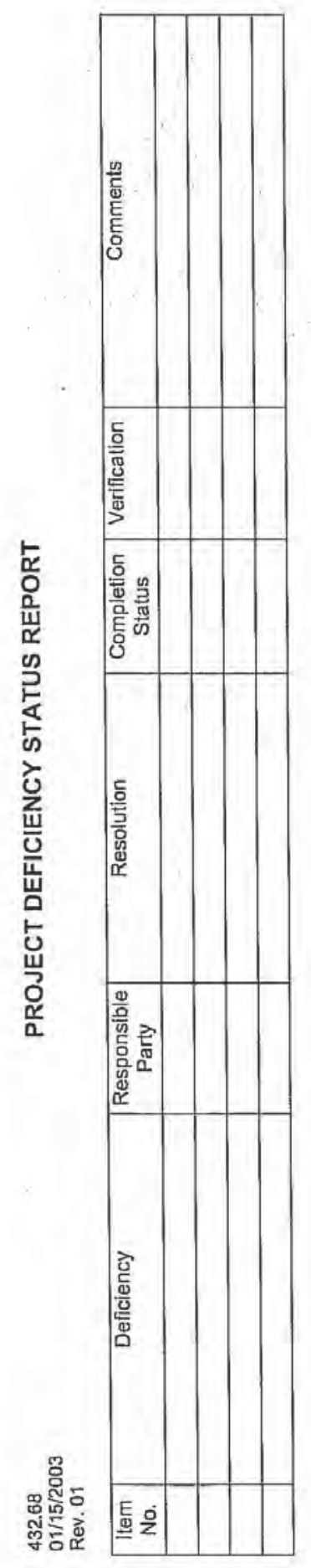




\section{Appendix A \\ Checklist for Partial Project Transfer \#4}

The following facility turnover checklists include the minimum activities required for partial and final facility transfer. Additional items may be added to the checklist if required by the Facility/System Tumover Review Committee.

Facility/Systems: Fire Alarm Notification and Reporting Systems: Criticality Alarm System.

Readiness Checklist for Partial Project Transfer \#4

\begin{tabular}{|l|l|l|l|l|}
\hline \multicolumn{2}{|c|}{ Deliverable or Activity } & \multicolumn{3}{c|}{ Completed? } \\
\cline { 3 - 5 } & Yes & No & N/A \\
\hline 1. & Final inspection walkthrough." & $X$ & & \\
\hline 2. & $\begin{array}{l}\text { Punch list items on Form 423.68, "Project Deficiency Status } \\
\text { Report." }\end{array}$ & $\mathrm{X}$ & & \\
\hline 3. & $\begin{array}{l}\text { List of deficiencies to be corrected and remaining activities } \\
\text { before and after partial project transfer as listed on Form 423.04, } \\
\text { "Inspection and Project Transfer." }\end{array}$ & $\mathrm{X}$ & & \\
\hline 4. & Relevant system inspections completed. & $\mathrm{X}$ & & \\
\hline \multicolumn{3}{|l}{} \\
\hline a. & The walkalirough ensures that all physical work requïred by the subcontract is substantially complete, \\
\hline
\end{tabular}

Appendix A 


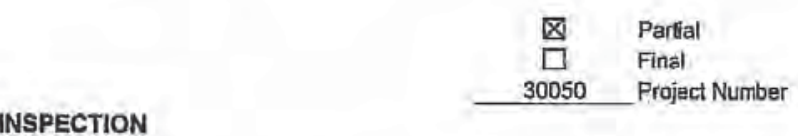

PROJECT TITLE: Material Security Consolldation Project (MSCP)

Partial Transfer \#4

as constructed by

C\&H Construction Inc

(Name of Subcontrector or Difrect Hilre)

119824

(Subcontract: No.)

(Funding No./Req. No.)

The project (or portion of the project) was found by the Project Team (signatures as shown below) to be complete in accordance with the contractual documents except for such deficlencles specilically noted below. The project (or portion of the project) is ready for testing and start-up aclivilles.

Deficiencies (attach list if necessary):

See Project Deficiciency Stalus Report (form 432.68)

Comments:

This Partial Project Transfer (H4) Includes:

1.) Fire Alam Nolification and Reporting Systems

2.) Critlicality Alarm System

PROJECT TEAM APPROVAL

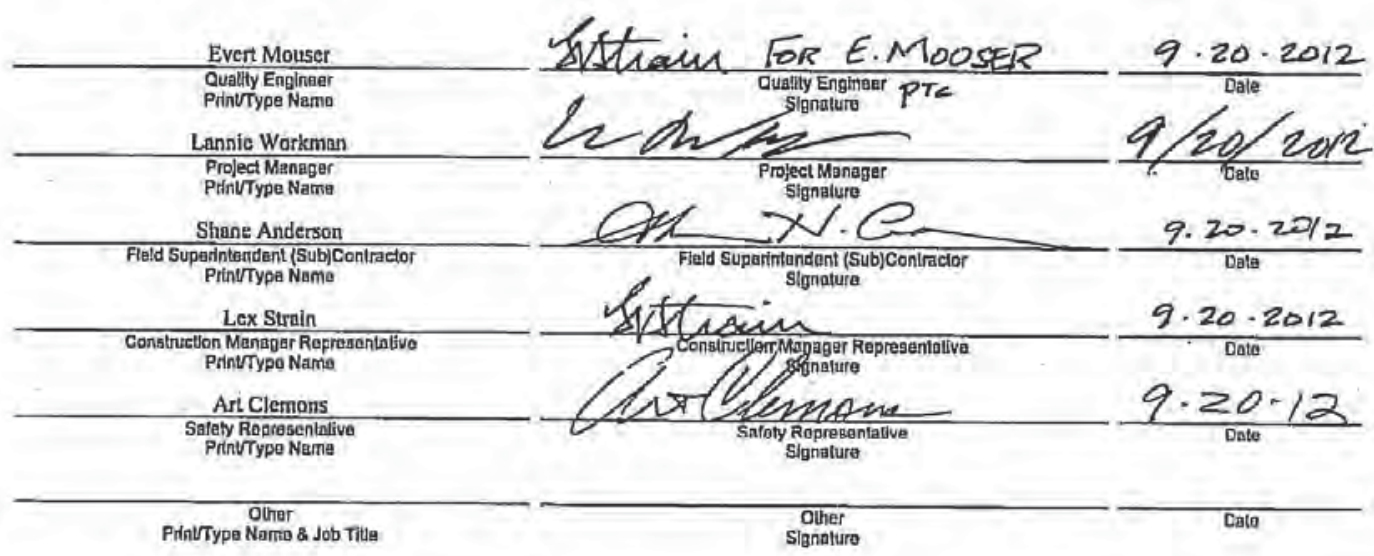




\section{PARTIAL PROJECT TRANSFER TO FACILITY MANAGER}

I certify that our personnel have monitored the design, fabrication, and installation of the project (or portion of the project) and, to the best of my knowledge, the work has been completed in accordance with the plans and technical specificallons, Including all approved changes. The project (or portion of the project) is hereby ready to be fumed over to the Facility Manager for system operaltonal testing and olher activities in preparatlon for final project transfer.

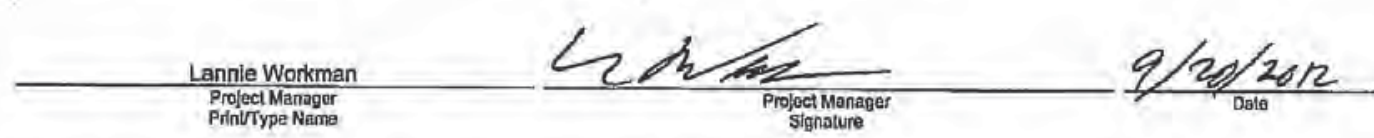

The Project Management Organiztion Facility Organization hereby accepts total responsibility for maintenance and cusiody of the project (or portion of the project) and for coordination of remaining testing and actlvilies required to prepare for final project transfer.

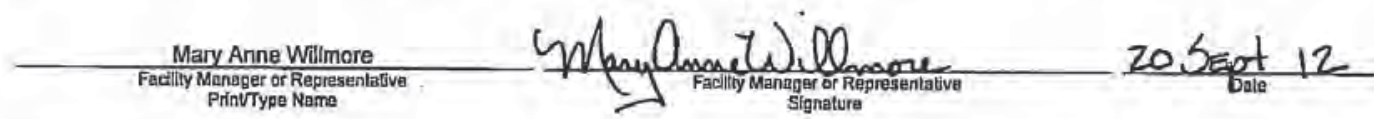

INTERIM DISTRIBUTION

Signalories, Land/Facility Operations, and Project Flle. For capital-funded projects include Property Accounting and Property Management.

\section{WORK COMPLETION}

\section{SUBCONTRACTORIDIRECT HIRE:}

I certify on behalf of C\&H Construction, Inc.

subject to the penalties provlded under 18 U.S.C., Section 1001, that our personnel have accomplished the contract work and, to the best of my knowledge, the work was periormed or accomplished in accordance with the contractual documenis, including all approved changes.

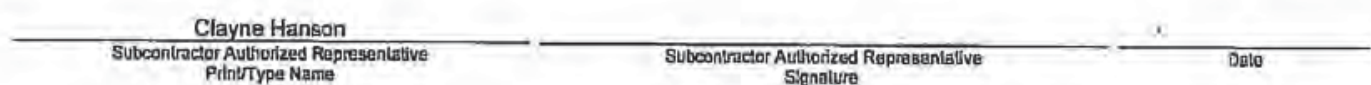

I certify that the administration of the contract for the above named project is, to the best of my knowledge, complete to the extent required for this Project Transfer and/or close out of the contract

Prodiremant Agent/ Construction Managar Representative
Printrype Narea


I certify completion of final testing and project review to ensure project requirements have been met in accordance with the Tumover and Acceplance Plan. The project (or portion of the project) is hereby ready to be turned over to the Facility Manager for acceptance.

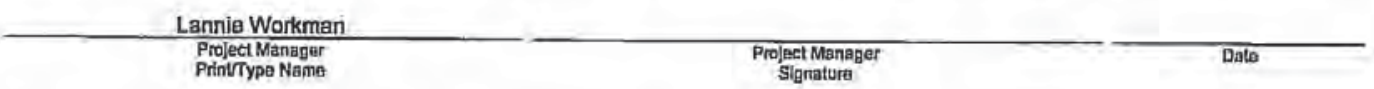

The project (or portion of the project) is hereby accepled for the Government.

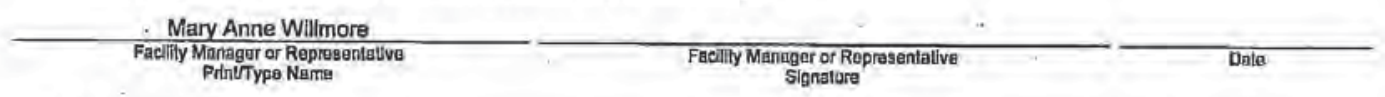

\section{FINAL DISTRIBUTION}

Signalories, plus DOE-ID Project Manager, Project File, and Land/Facility Operalions. For capital-funded projects, Include Property Accounting. Property Management, and Financial Construction Coordinator.

\section{INSTRUCTIONS}

In accordance with MCP-2869, "Project Turnover and Acceptance," this farm docurnents the final inspection between the subcontractort direct hire and the Facility Manager, and effects partial and final transfers of the project (or portion of the project) to the Facility Manager.

INSPECTION

1. The "Inspection" section is to be used for both partial and final project transfers. In general, a partial project transfer occurs when the contract or a specific and definable portion of the project has been completed and is to be tumed over to the Facillty Manager for cuslody and maintenance. Iterns such as SO Tesfing, Lifa' Safety System tie-ins, terminations, and final project documentation still remaln to be accomplished.

2. The description needs to be detalled and clear on what is being transferred (e.g., reference drawing list, equipment llst).

3. Deficiencies should only be allowed for partial transfers. If possible, include planned completion date for each deficlency.

4. Quality Engineer signs for quality significant projects, Field Engineer signs for Consumer Grade projects, or bolth sign for projects that are combined activities.

\section{PARTIAL PROJECT TRANSFER APPROVAL}

1. The "Partial Praject Transfer to Facility Manager" section is to be filled out for partial project transfar of the project (or portion of the project) from the subcontractor/direct hire to the Facility Manager after review by the Project Turnover Review Committee demonstrates that the project (ar portion of the project) is sale and ready for occupancy and SO Testing activities.

\section{WORK COMPLETION}

1. The "Work Completlon" section is to be filled out to cerlify coniract work is complele. This is to be done in conjunctlon with the Final Project Transfer.

\section{FINAL PROJECT TRANSFER APPROVAL}

1. The "Final Project Transfer" section is to be filled out afler final testling (such as So fesling), complation of all remaining project aclivities, and review by the Project Tumover Review Committee demonstrate thal the project (or portion of the project) is ready fo acceptance by the Facility Manager/user organization.

2. Use of this form daes not consilitute start-up approval of the project or portion thereof. 


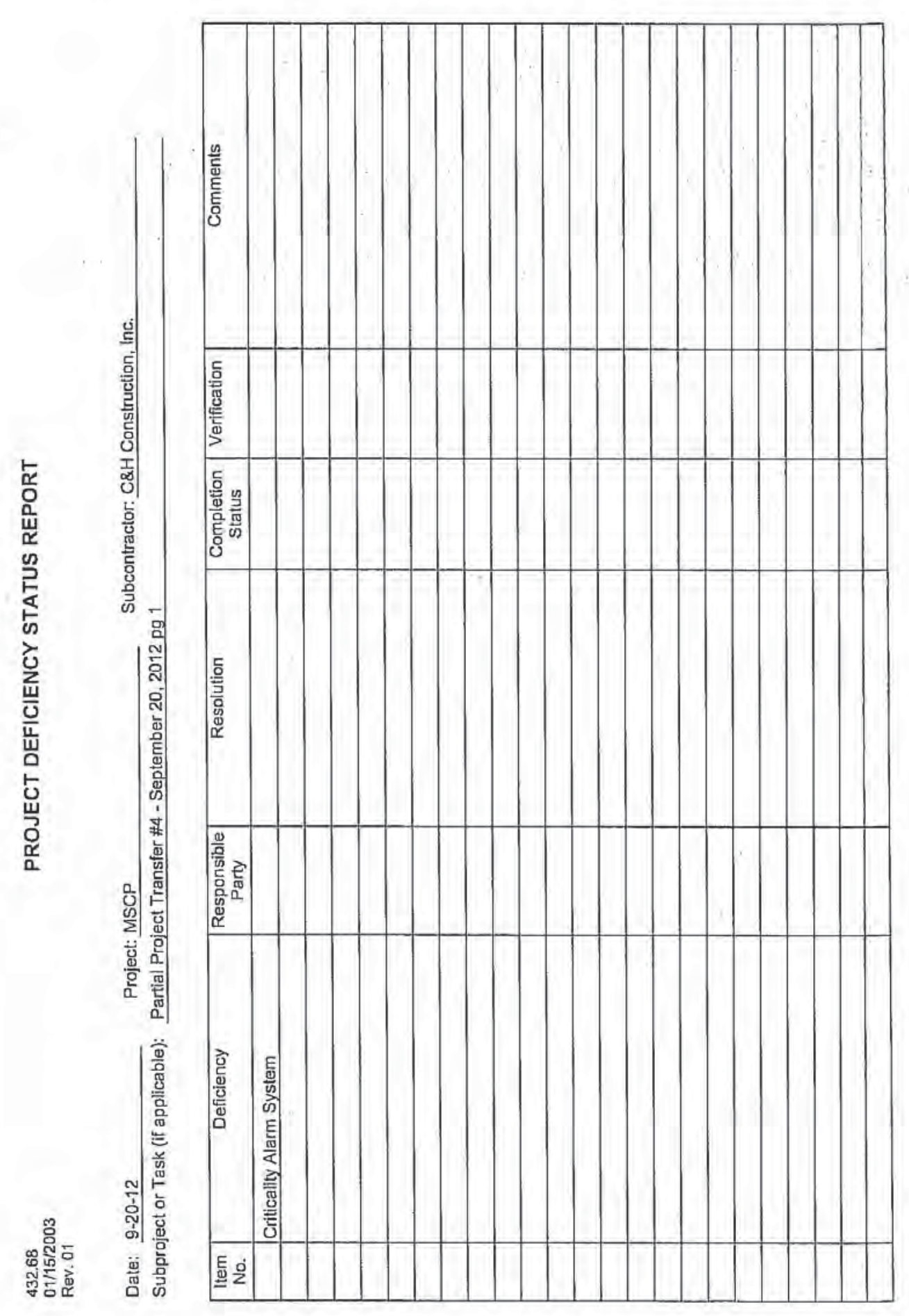




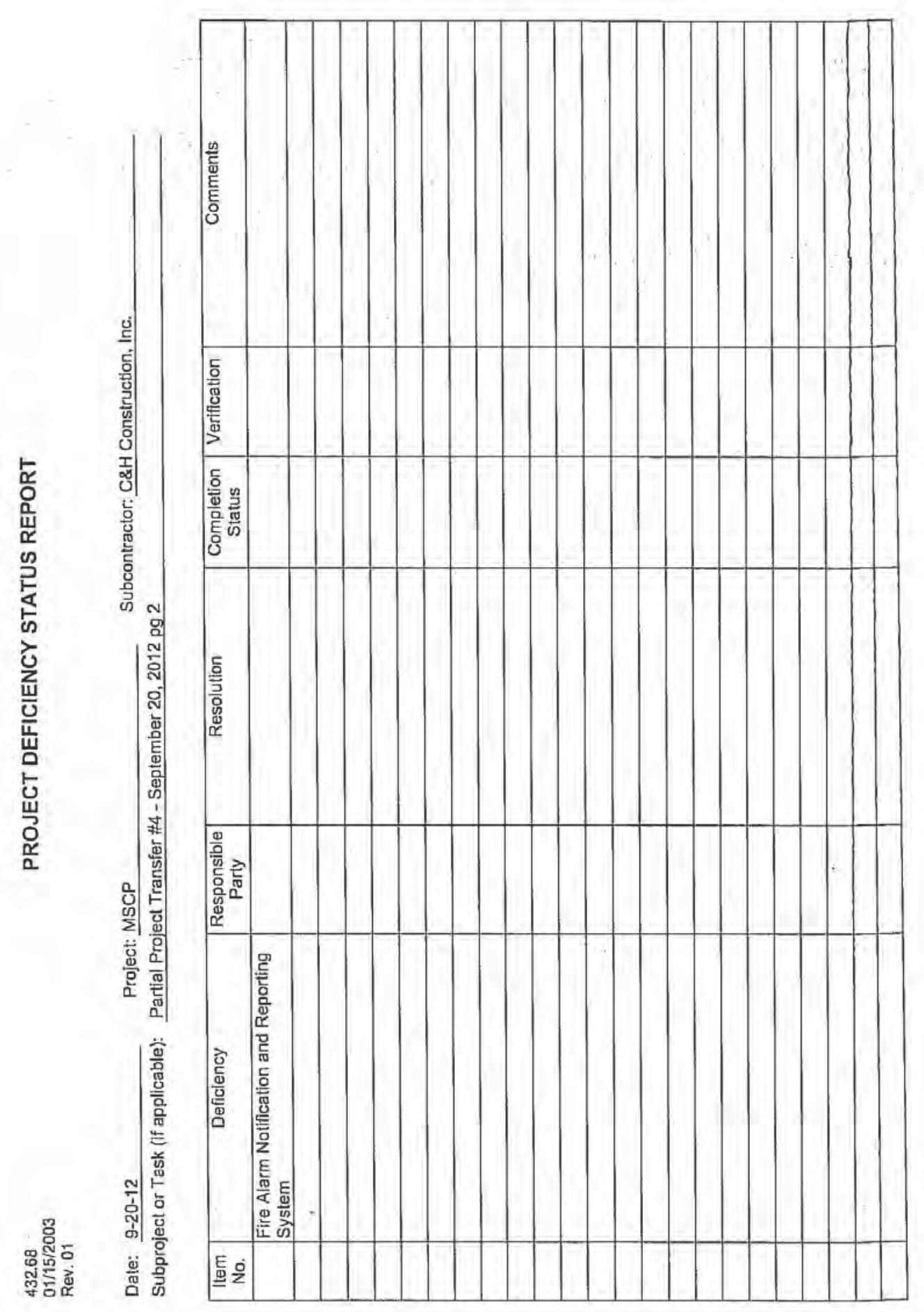


Idaho Nationnl Laboratory

\begin{tabular}{|c|c|c|c|}
\hline $\begin{array}{l}\text { MATERIAL SECURITY AND } \\
\text { CONSOLIDATION PROJECT }\end{array}$ & $\begin{array}{l}\text { Identifier: } \\
\text { Revision: } \\
\text { Effective Date: }\end{array}$ & $\begin{array}{l}\text { PLN-4173 } \\
1 \\
10 / 11 / 2012\end{array}$ & Page: 21 of 24 \\
\hline
\end{tabular}

Appendix B

Checklist for Baseline Final Project Transfer (sce exclusions noted in checklist)

\begin{tabular}{|c|c|c|c|c|}
\hline \multirow{2}{*}{\multicolumn{2}{|c|}{ 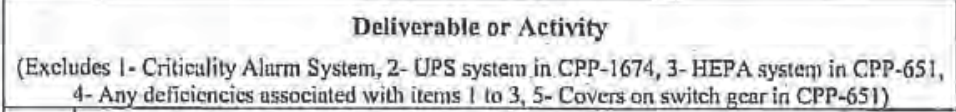 }} & \multicolumn{3}{|c|}{ Completed? } \\
\hline & & \multirow{2}{*}{$\mathrm{X}$} & \multirow[t]{2}{*}{ No } & \multirow[t]{2}{*}{ NA } \\
\hline 1. & $\begin{array}{l}\text { Applicable construction subcontractor equipment testing and System Operability } \\
\text { (SO) tesling performed and test results approved. }\end{array}$ & & & \\
\hline 2. & $\begin{array}{l}\text { Drawings including as-builts of essential and master facility drawings are } \\
\text { complete. }\end{array}$ & $\mathrm{x}$ & & \\
\hline 3. & $\begin{array}{l}\text { Submittal of project documents needed for operalion (vendor data, spare parts, } \\
\text { preventive maintenance, etc.) to the System Engineer's organization. }\end{array}$ & $\mathrm{x}$ & & \\
\hline 4. & $\begin{array}{l}\text { Occupancy requirements completed such as: } \\
\text { - Signs } \\
\text { - Access restrictions } \\
\text { - } \text { Personal protective equipment } \\
\text { - Other safety equipment. }\end{array}$ & $x$ & & \\
\hline 5. & $\begin{array}{l}\text { Punch-list items (listed in the "Deficiencies" section of Form 423.04) have been } \\
\text { completed or transferred to a deficiency tracking system. }\end{array}$ & $\mathrm{x}$ & & \\
\hline 6. & Inspection plans completed and closed. & $\mathrm{x}$ & & \\
\hline 7. & Engineering Job Form (EJ), completed. & $\mathrm{x}$ & & \\
\hline 8. & Environmental permits/regulatory notifications/documentation completed. & $\mathrm{X}$ & & \\
\hline 9. & $\begin{array}{l}\text { All required equipment identified and entered into the facility master equipment } \\
\text { list, "Master Equipment List and Maintenance History." }\end{array}$ & $\mathrm{x}$ & & \\
\hline 10. & Approved and issued Maintenance work orders as they become due. & $\mathrm{x}$ & & \\
\hline $1 \mathrm{I}$. & $\begin{array}{l}\text { Personnel training requirements are established and complete. This includes } \\
\text { system configuration for mainienance personnel. }\end{array}$ & $\mathrm{X}$ & & \\
\hline 12. & Maintenance personnel training plans developed. & $\mathrm{X}$ & & \\
\hline 13. & Maintenance personnel training completed. & $\mathrm{X}$ & & \\
\hline 14. & Maintenance work orders are complete and ready for use & $\mathrm{x}$ & & \\
\hline 15. & $\begin{array}{l}\text { Notification to plant shift supervisors on the conliguration and operational changes } \\
\text { being implemented. }\end{array}$ & $x$ & & \\
\hline 16. & Notification to Fire Department of project turnover. & $\mathrm{X}$ & & \\
\hline 17. & Responsibility for swarranty work is transferred to the facility & $\mathrm{x}$ & & \\
\hline 18. & Required/critical spare parts are available & $\mathrm{x}$ & & \\
\hline 19. & Emergency management requirements have been updated & $\mathrm{x}$ & & \\
\hline 20. & Operations personnel have been trained & $\mathrm{x}$ & & \\
\hline $2 \mathrm{I}$. & Vulnerability assessment has been completed & $\mathrm{x}$ & & \\
\hline 22. & $\begin{array}{l}\text { Notification lo facility manager of any abandoned energy sources that cannot be } \\
\text { removed. }\end{array}$ & $\mathrm{x}$ & & \\
\hline
\end{tabular}

Appendix B 


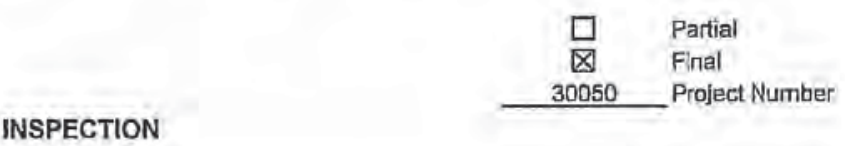

PROJECT TITLE: Material Security Consolidation Project (MSCP)

as constructed by

C\&H Construction Inc

(Name of Subcontractor or Direct Hire)

119824

(Subcontracl No)

(Funding No/Req. No.)

The project (or portion of the project) was found by the Project Team (signatures as shown below) to be complete in accordance with the contractual documents except for such deficiencles specifically noted below. The project (or portion of the project) is ready for testing and slart-up activities.

Deficiencies (attach list if necessary):

Comments:

This is the Final Project Transfer for all systems necessary for the receipt of the Spent Fuel Treatment Product (SFTP).

This Final Poject Transfer excludes the following systems:

1.) Crillcality Alam Syslem

2.) Uninteruptable Power Supply (UPS) System

3.) HEPA System in CPP-B51

4.) Any outstanding project deficiencies related to systems 1 through 3 . These deficiencies are identified on the Project Deficiency

Status Report, form 432.68

5.) Covers on switch gear in CPP-651 vestibule to be installed during LC-2 oulage for UPS, scheduled 10/18/2012

\section{PROJECT TEAM APPROVAL}

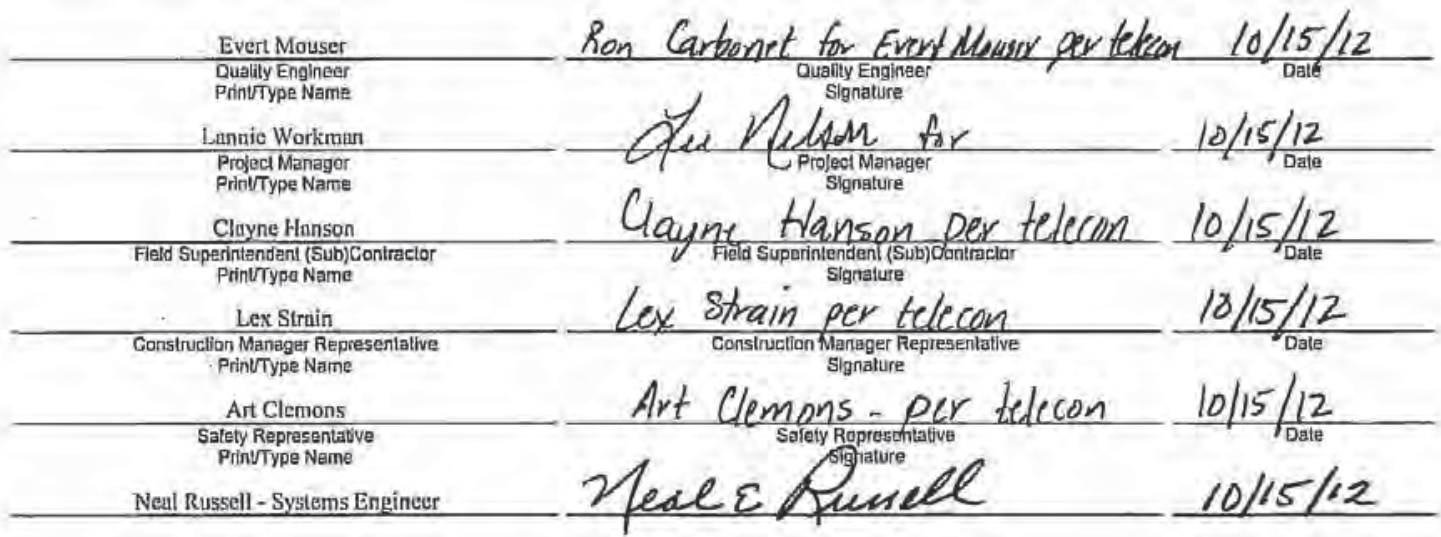




\section{PARTIAL PROJECT TRANSFER TO FACILITY MANAGER}

I certify that our personnel have monitored the design, fabrication, and installation of the project (or portion of the project) and, to the best of my knowledge, the work has been completed in accordance with the plans and technical specifications, including all approved changes. The project (or portion of the projecl) is heraby ready to be turned over to the Facility Manager for system operational tesilng and other activities in preparalion for final project transfer.

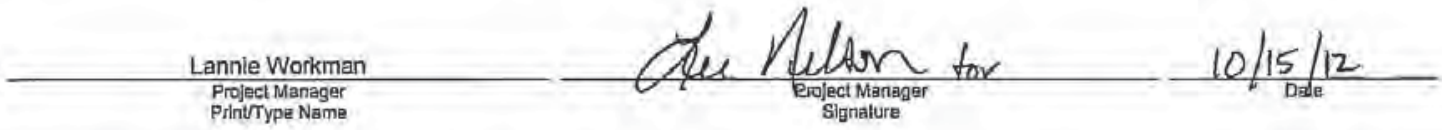

The MFC Nuclear Operations

Facility Organization hereby accepts total responsiblity for maintenance and custody of the project (or portion of the project) and for coordination of remaining lesting and activities required to prepare for final project transfer.

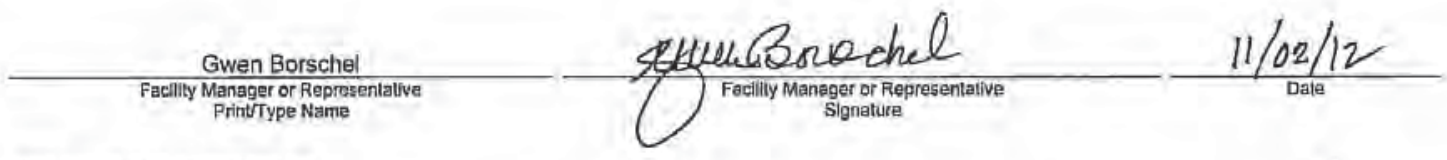

\section{INTERIM DISTRIBUTION}

Signalories, Land/Fecility Operations, and Project Flle. For capital-Tunded projects include Property Accounling and Property Management.

\section{WORK COMPLETION}

\section{SUBCONTRACTOR/DIREGT HIRE:}

I cerlify on behalf of $\mathrm{C} \& \mathrm{H}$ Construction, Inc.

subject to the penalties provided under 18 U.S.C., Section 1001, that our personnel have accomplished the contract work and, to the best of my knowledge, the work was performed or accomplished in accordance with the contractual documents, including all approved changes.

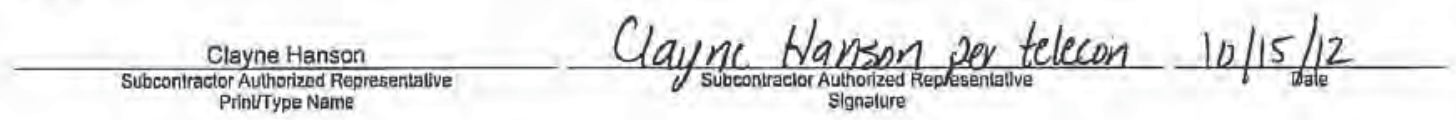

I certify that the administration of the contract for the above named project is, to the besl of my knowledge, complele to the extent required for this Project Transfer and/or close out of the contracl 


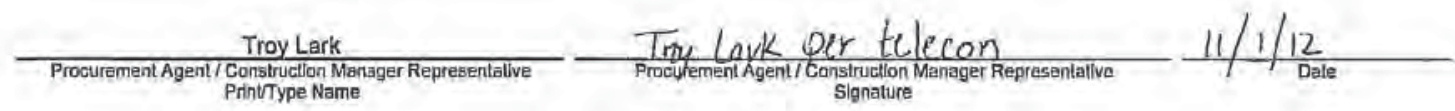

I certify completion of final testing and project review to ensure project requirements have been met in accordance with the Turnover and Acceptance Plan. The project (or portion of the project) is hereby ready to be turned over to the Facility Manager for acceptance.

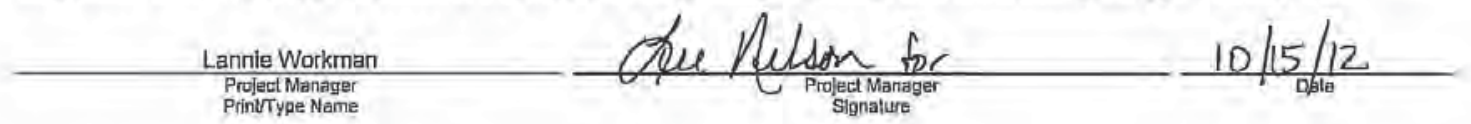

The project (or portion of the project) is hereby accepted for the Government.

The project (or portion of the project) is hereby accepted for the Government.
Gwen Borschel
Facillty Manager or Representalive
Printrype Narne

\section{FINAL DISTRIBUTION}

Signatories, plus DOE-ID Project Manager, Project File, and Land/Facility Operations. For capital-funded projects, include Property Accounting, Property Management, and Financial Construction Coordinalor.

\section{INSTRUCTIONS}

In accordance with MCP-2869, "Project Turnover and Acceptance," this form dacuments the final inspection between the subcontractor/ direct hire and the Facility Manager, and effects partial and final transfers of the project (or portion of the project) to the Facility Manager.

\section{INSPECTION}

1. The "Inspection" section is to be used for both partial and final project transfers. In general, a partial project transfer occurs when the contract or a specific and definable portion of the project has been completed and is to be turned over to the Facility Manager for custody and maintenance. Items such as SO Testing, Life Safety System tie-lns, terminations, and final project dacumentation still remain to be accomplished.

2. The description needs to be defailed and clear on what is being transferred (e.g., reference drawing list, equipment list).

3. Deficiencies should only be allowed for partial transfers. If possible, include planned completion date for each deficlency,

4. Quality Engineer signs for quality significant projects, Field Engineer signs for Consumer Grade projects, or both sign for projecls that are combined activitles.

\section{PARTIAL PROJECT TRANSFER APPROVAL}

1. The "Partial Project Transfer lo Facility Manager" section is to be filled out for partial project transfer of the project (or portion of the project) from the subcontractorldirect hire to the Facility Manager after review by the Project Tumover Review Committee demonsirates that the project (or portion of the project) is safe and ready for occupancy and SO Tesling activities.

\section{WORK COMPLETION}

1. The "Work Completion" section is to be filled oul to certify contracl work is complete. This is to be done in conjunction with the Final Project Transier.

\section{FINAL PROJECT TRANSFER APPROVAL}

1. The "Final Project Transfer" section is to be filled out after final testing (such as so testing), completion of all remaining project 
Rev. 09

activities, and review by the Project Turnover Review Committee demonstrate that the project (or portion of the project) is ready for acceptance by the Facility Manager/user organization.

2. Use of this form does not constitute start-up approval of the project or portion thereof. 


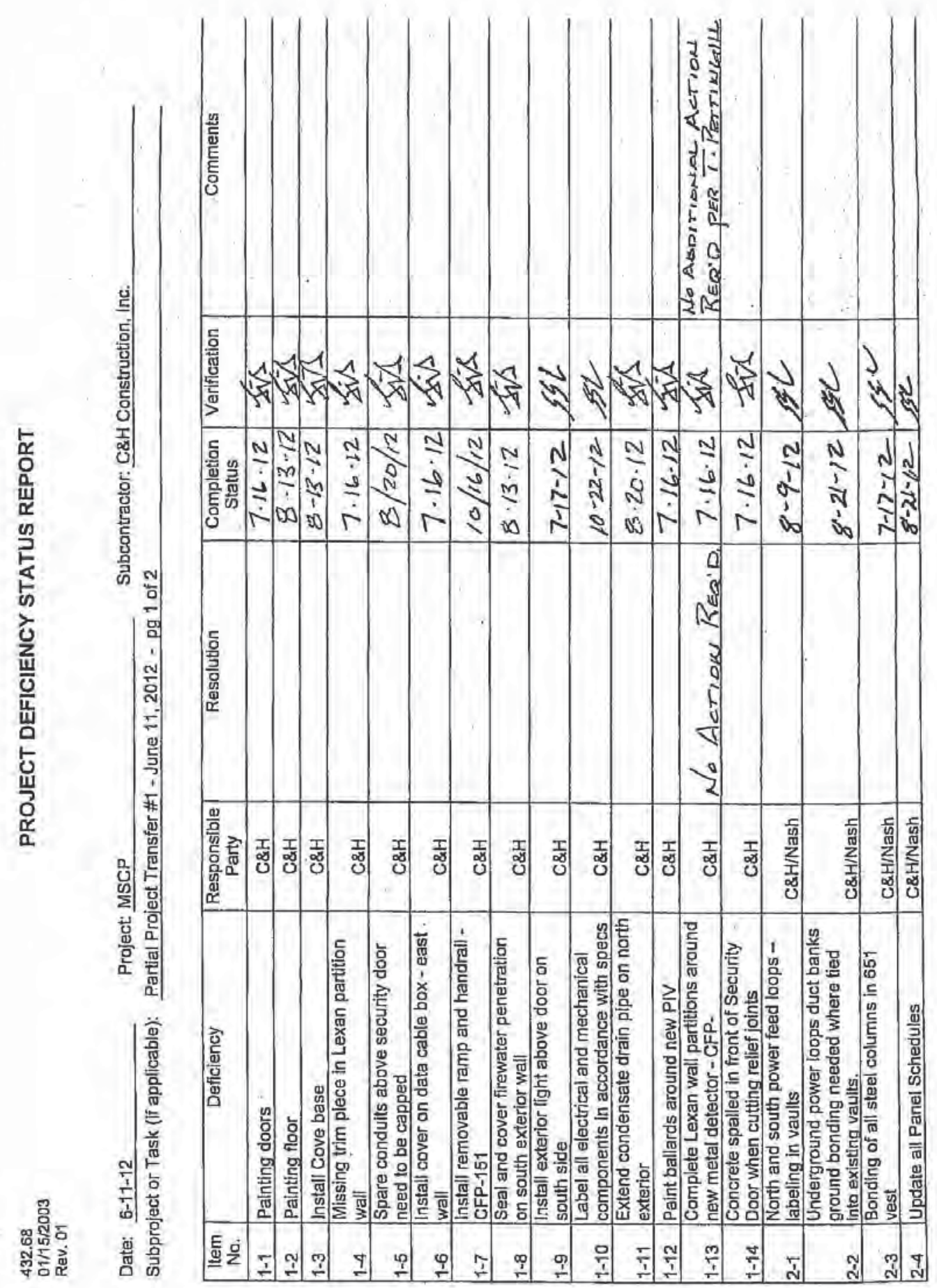




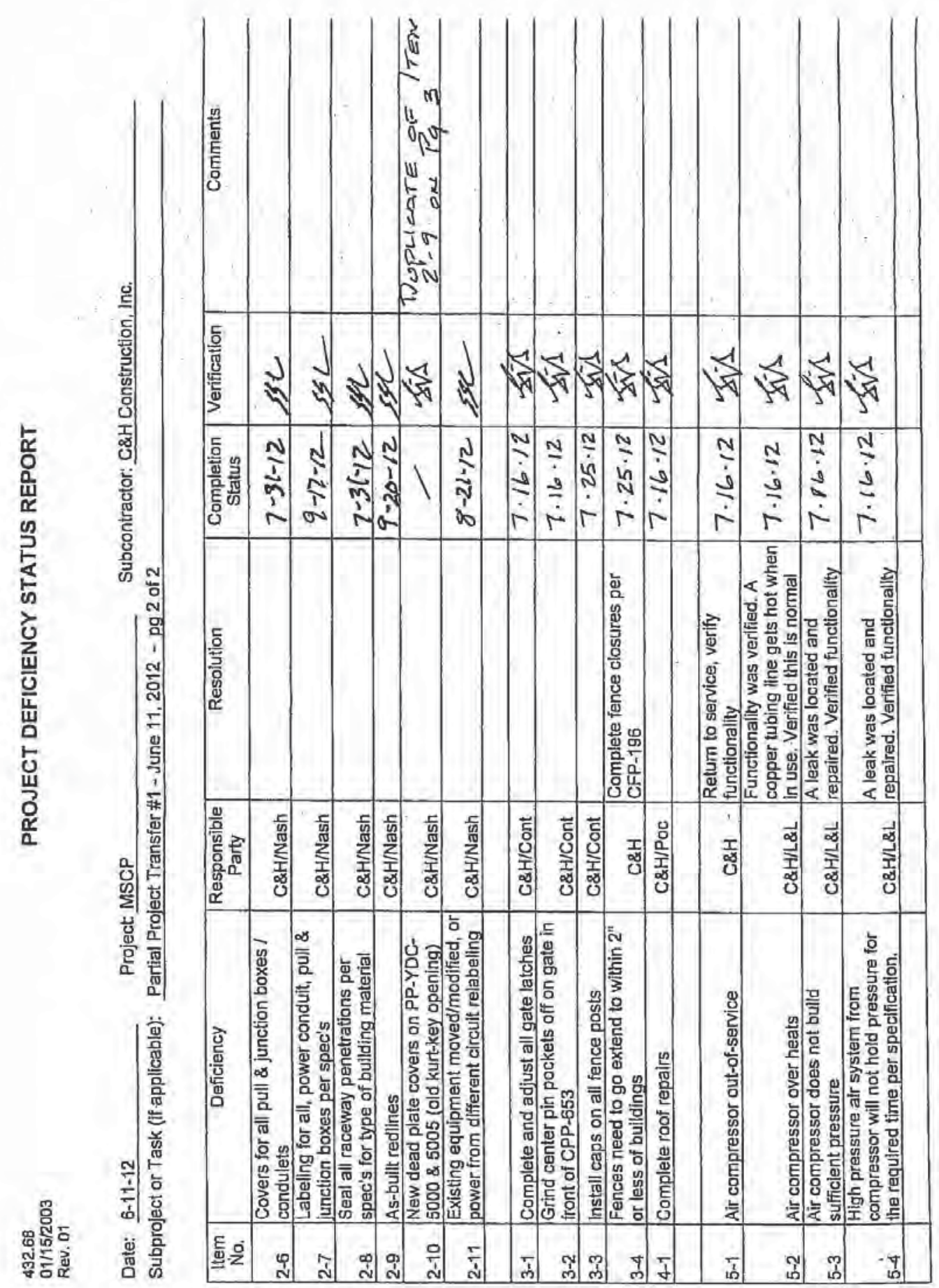




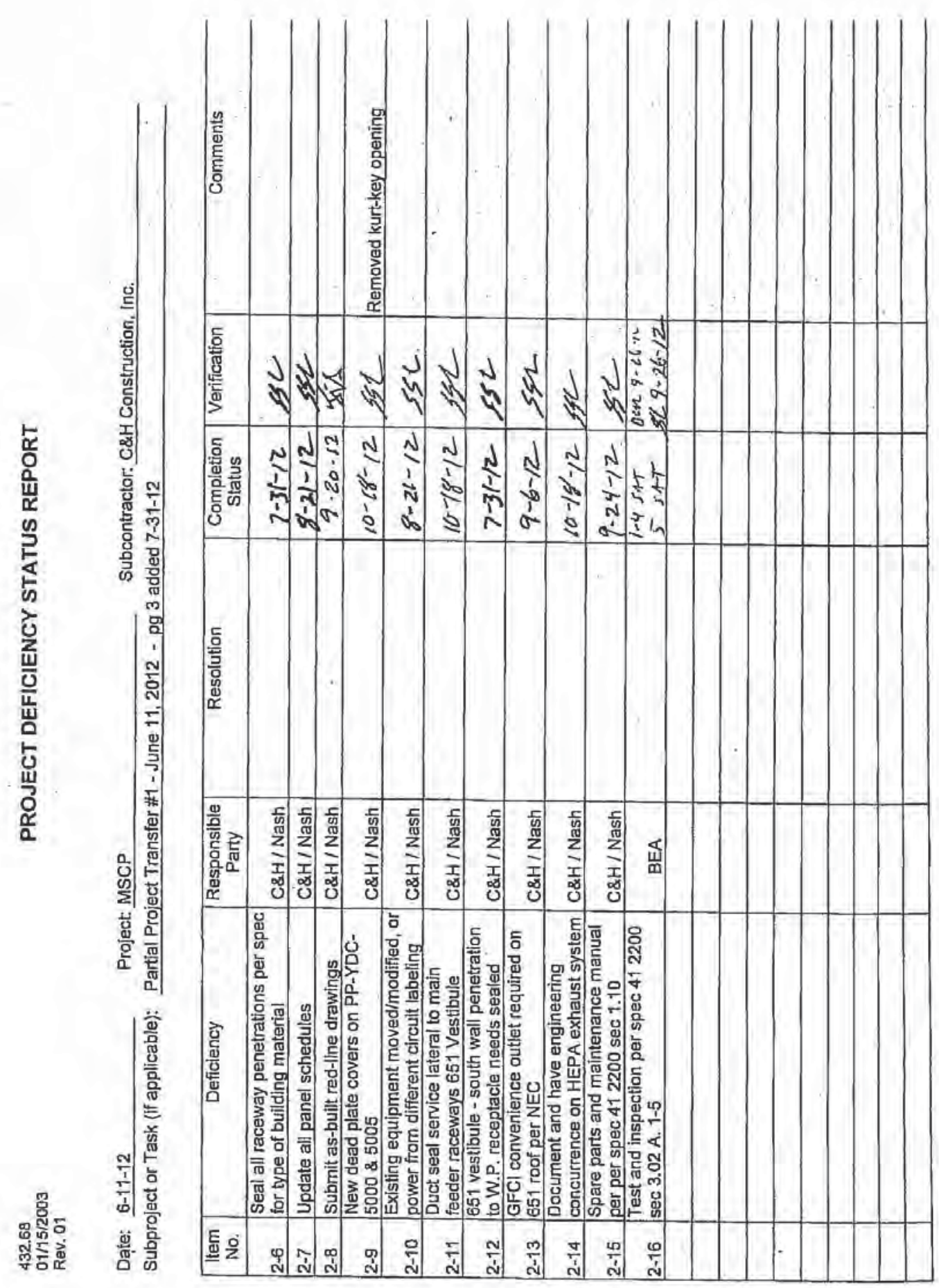




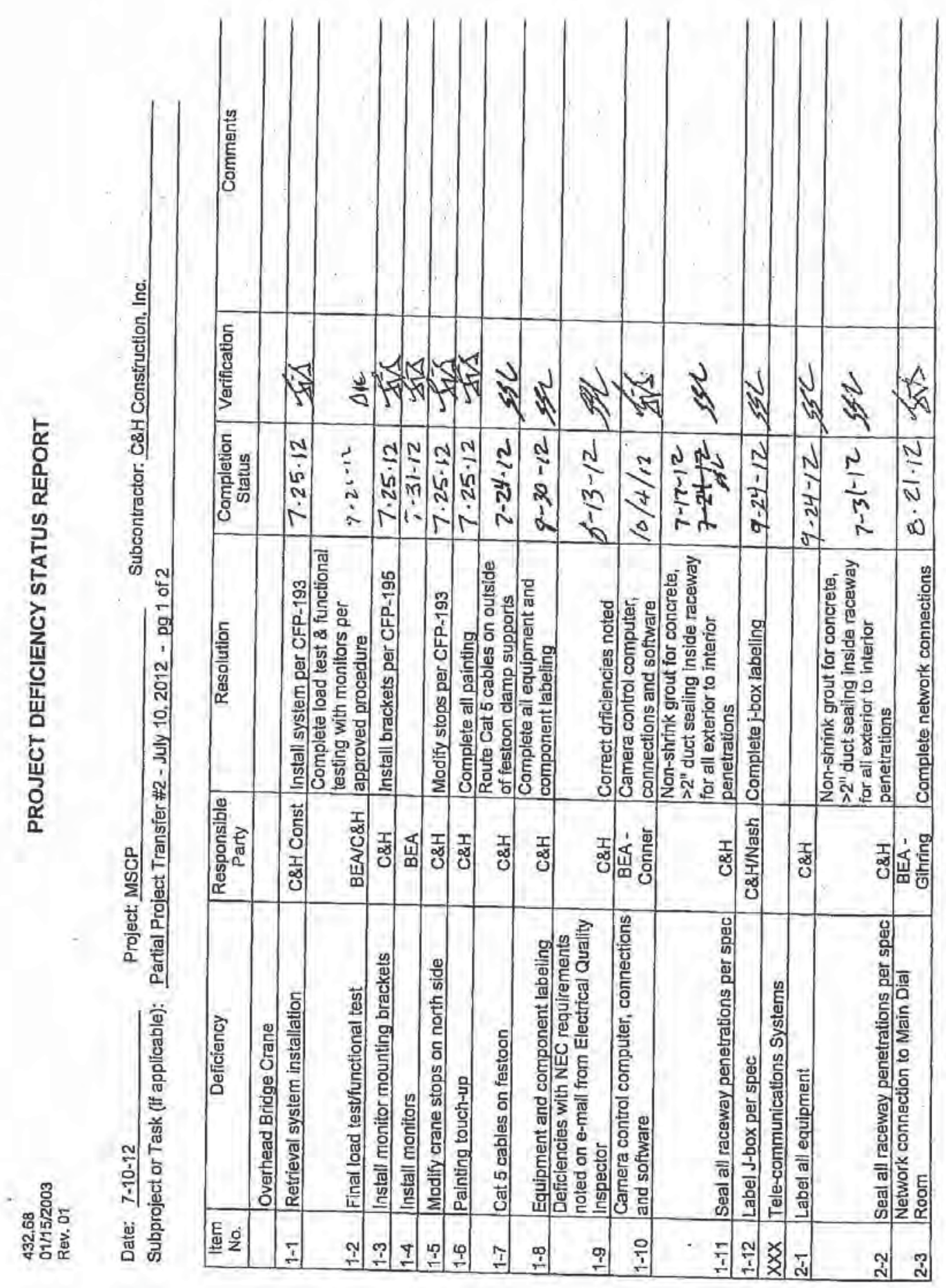




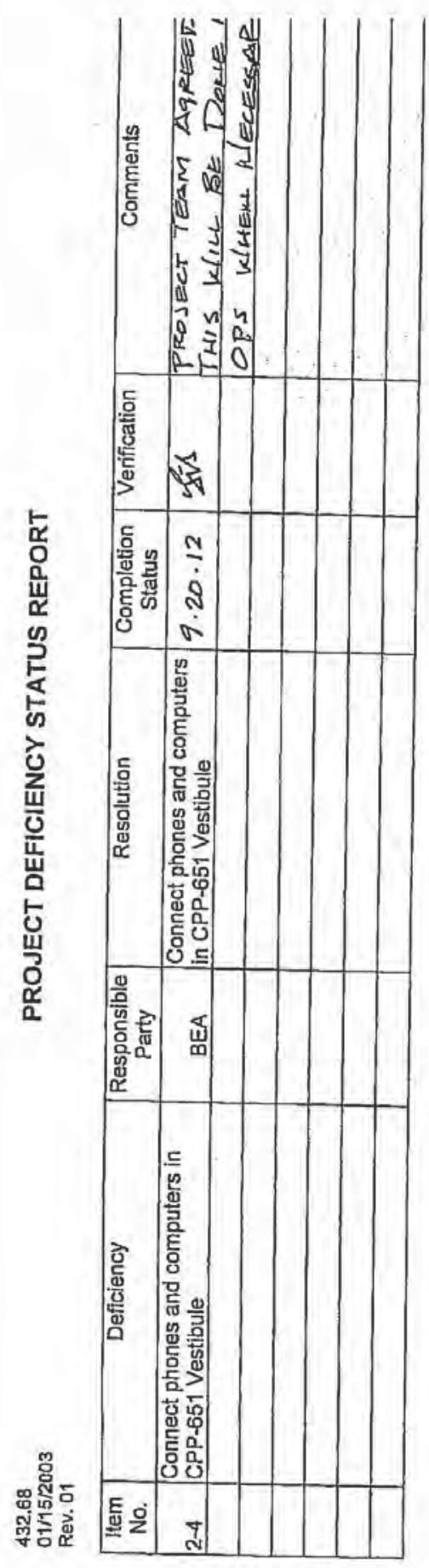




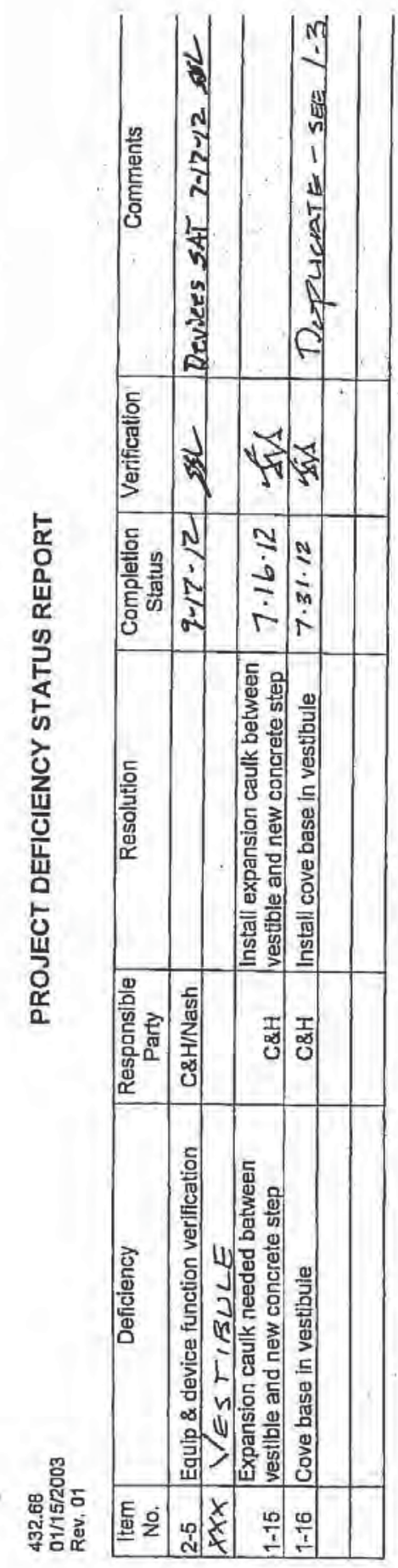




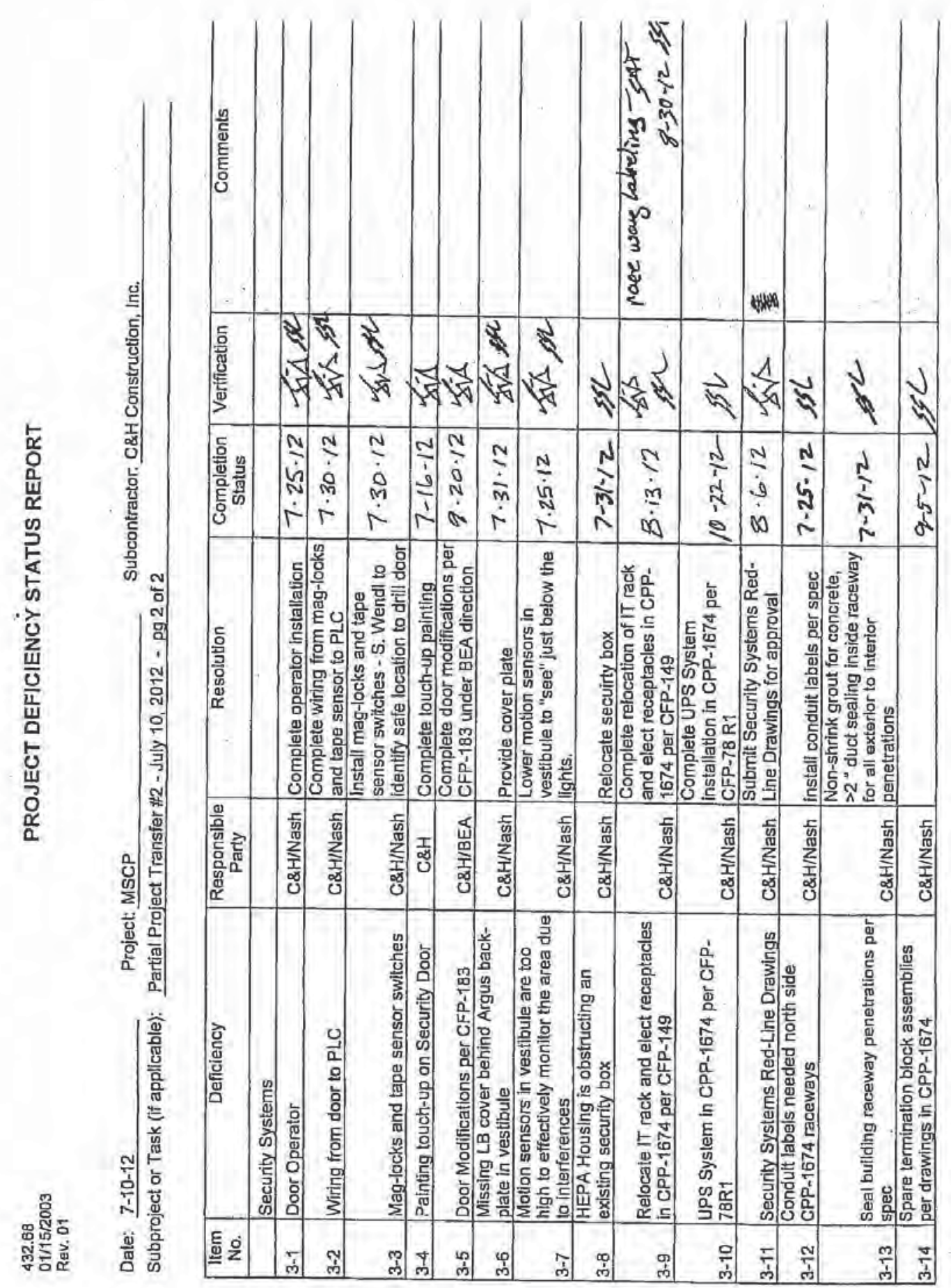




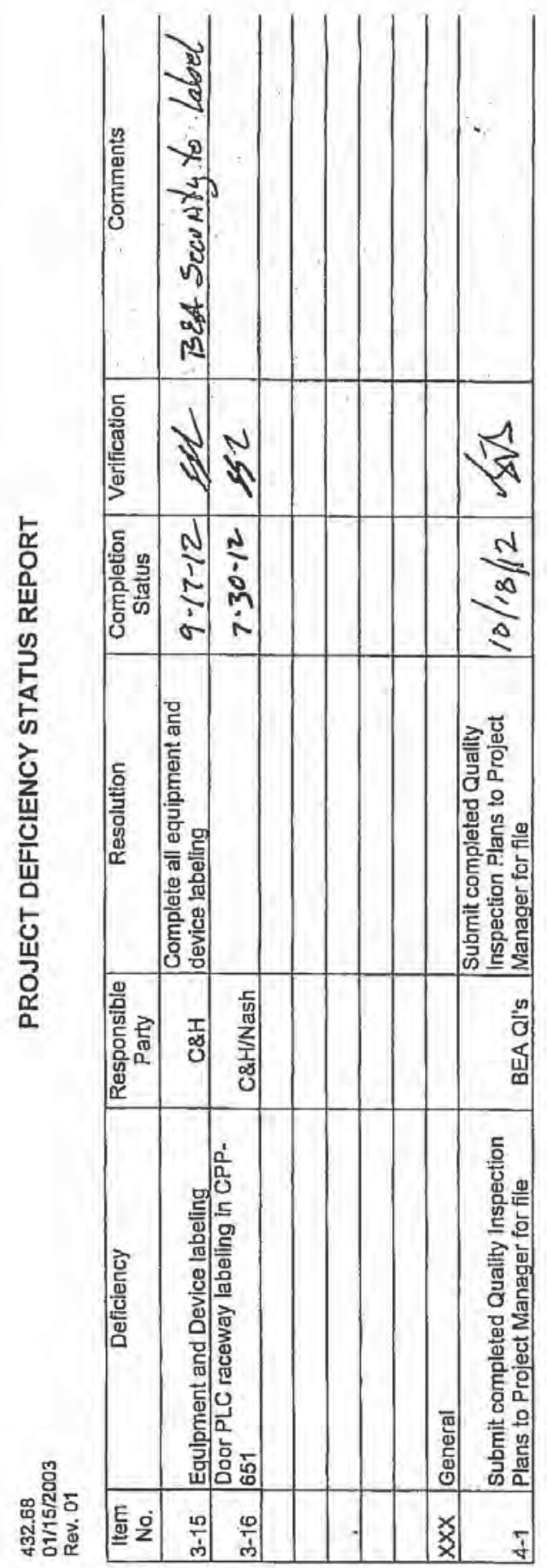




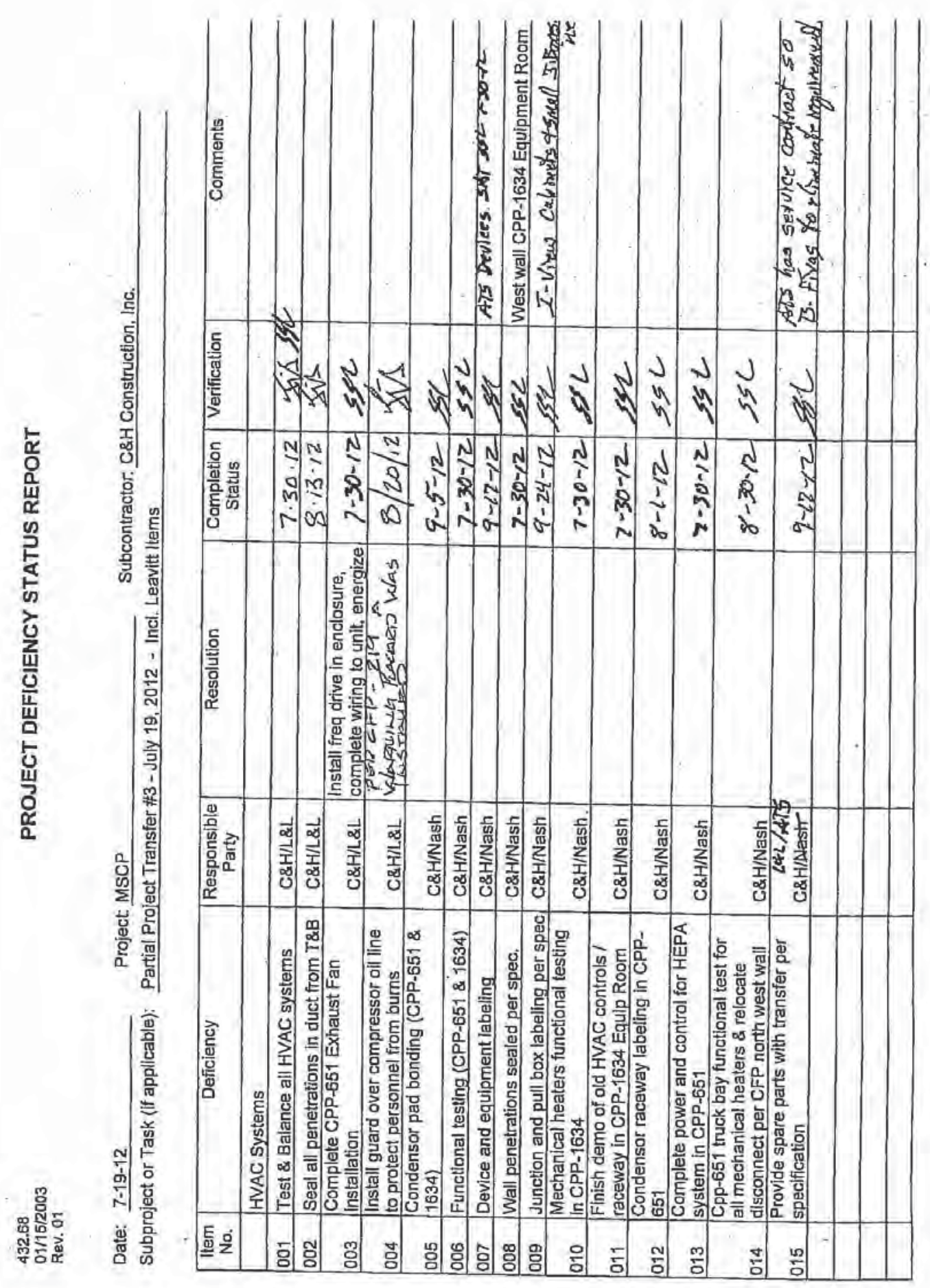




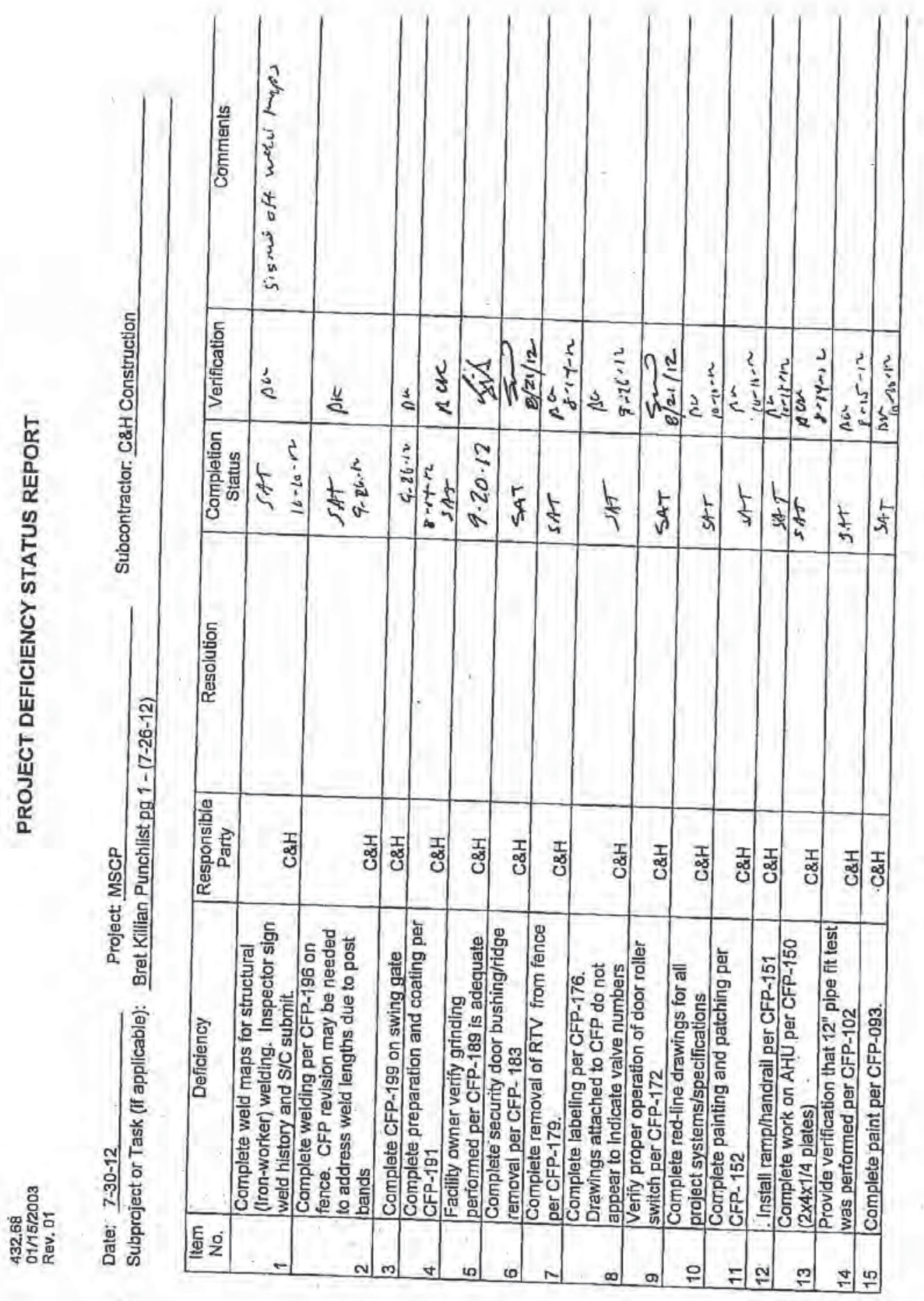




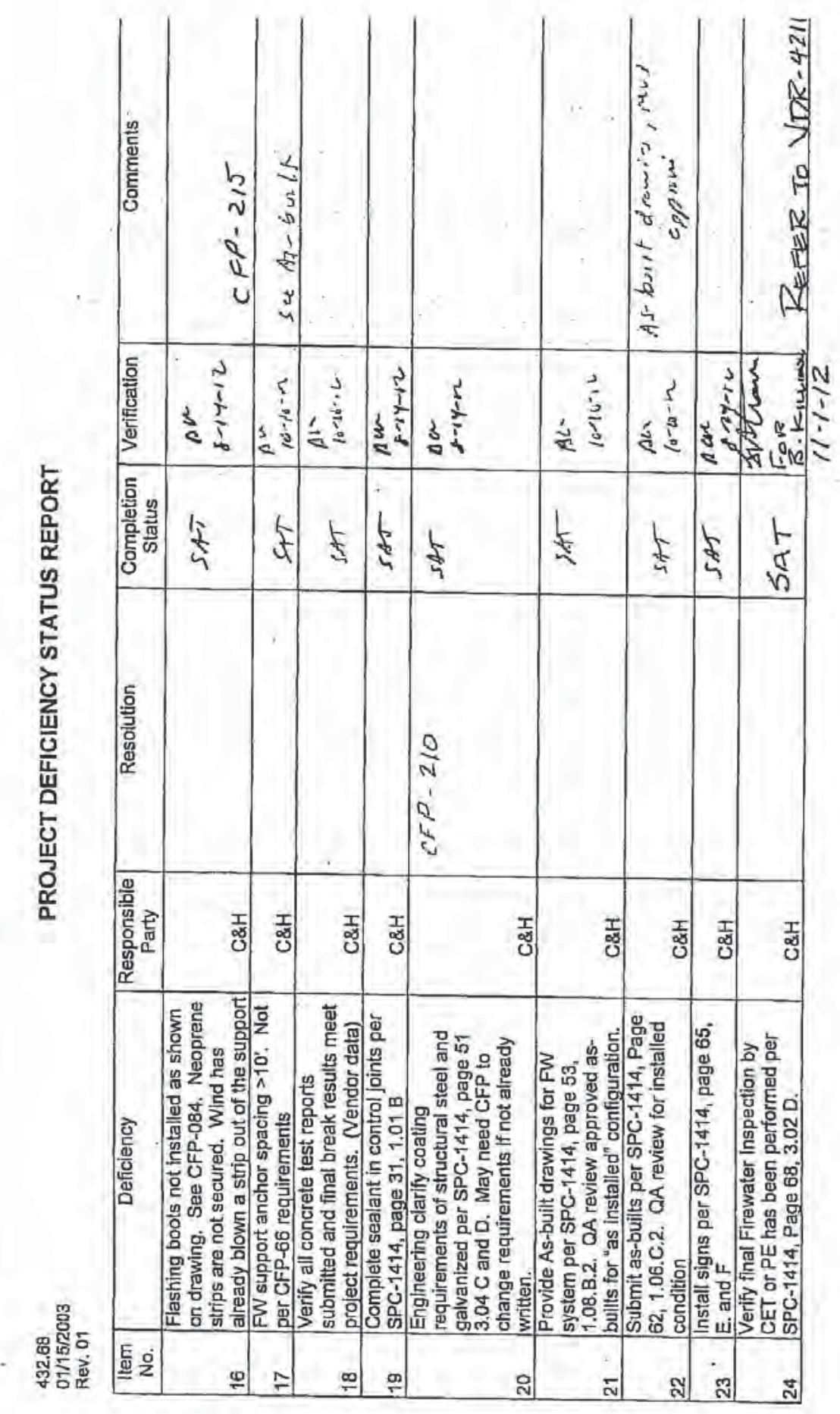




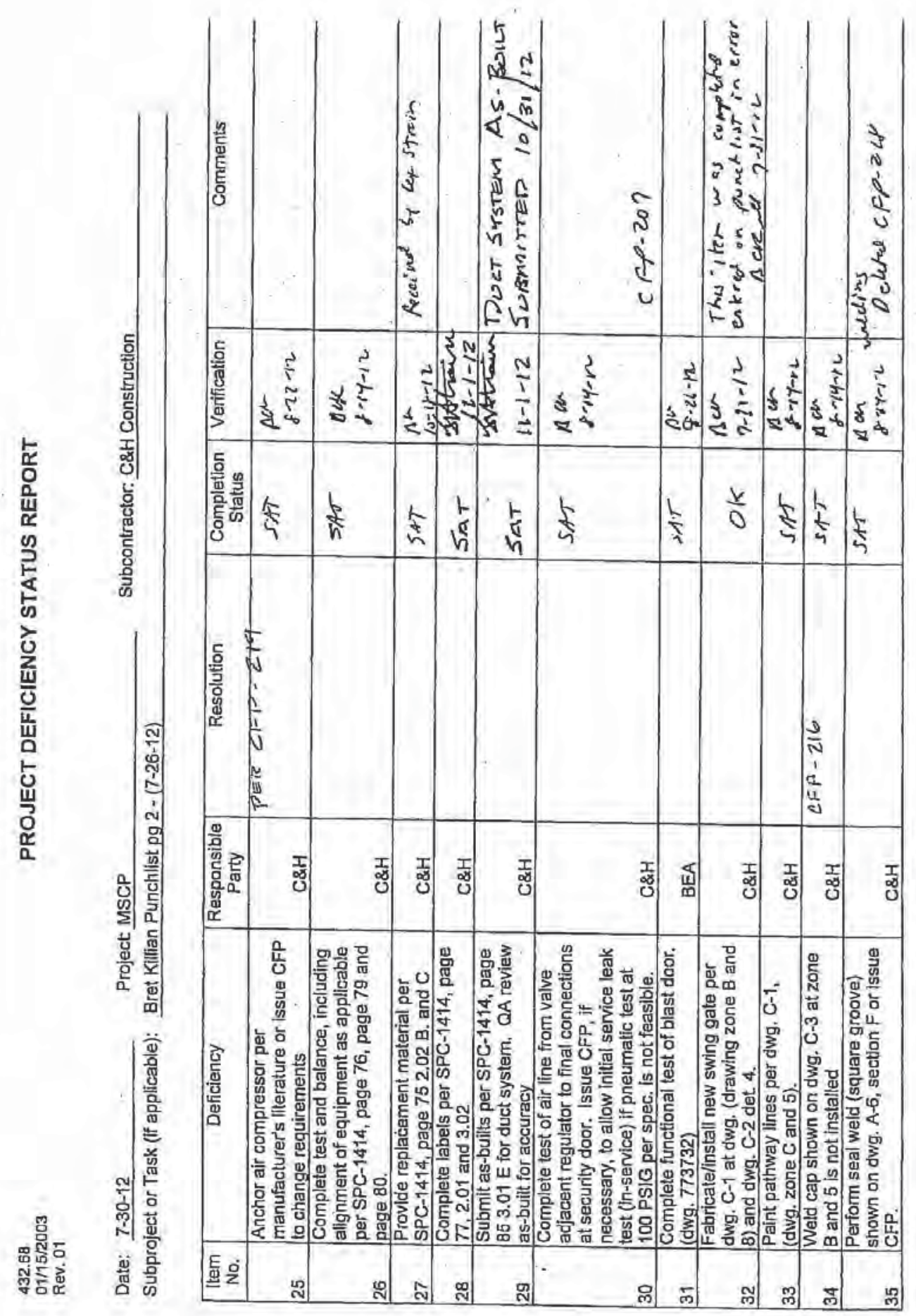




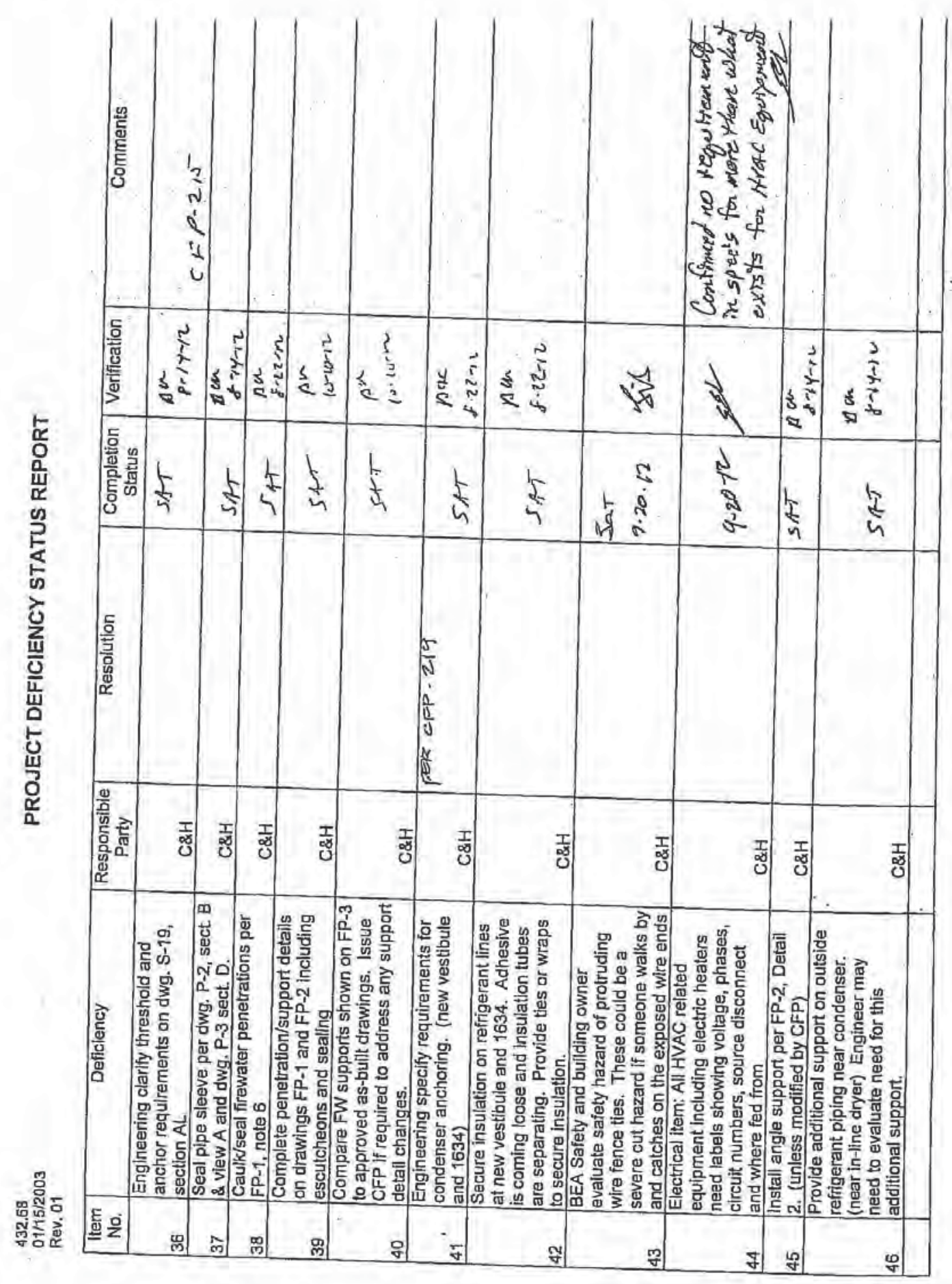




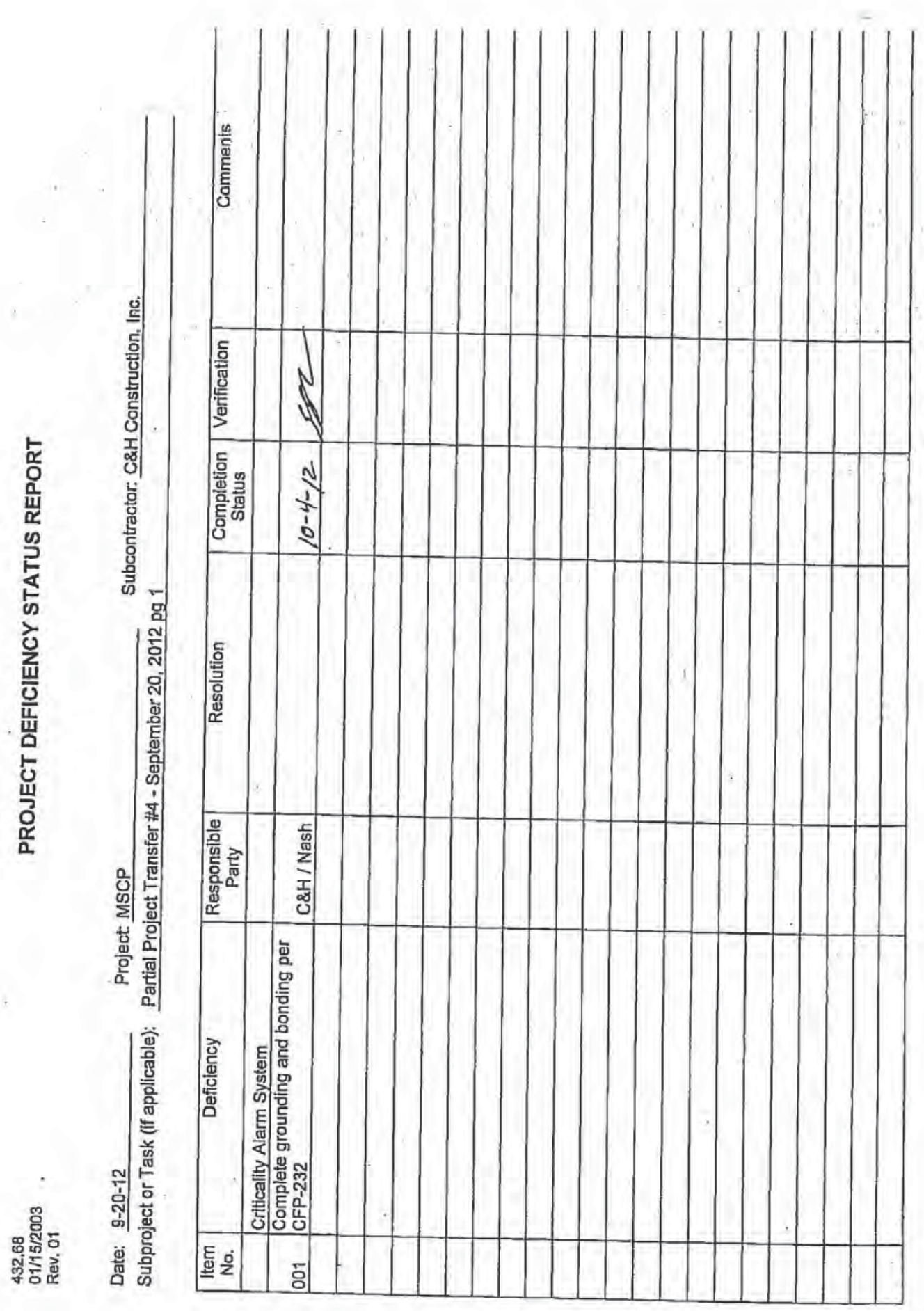




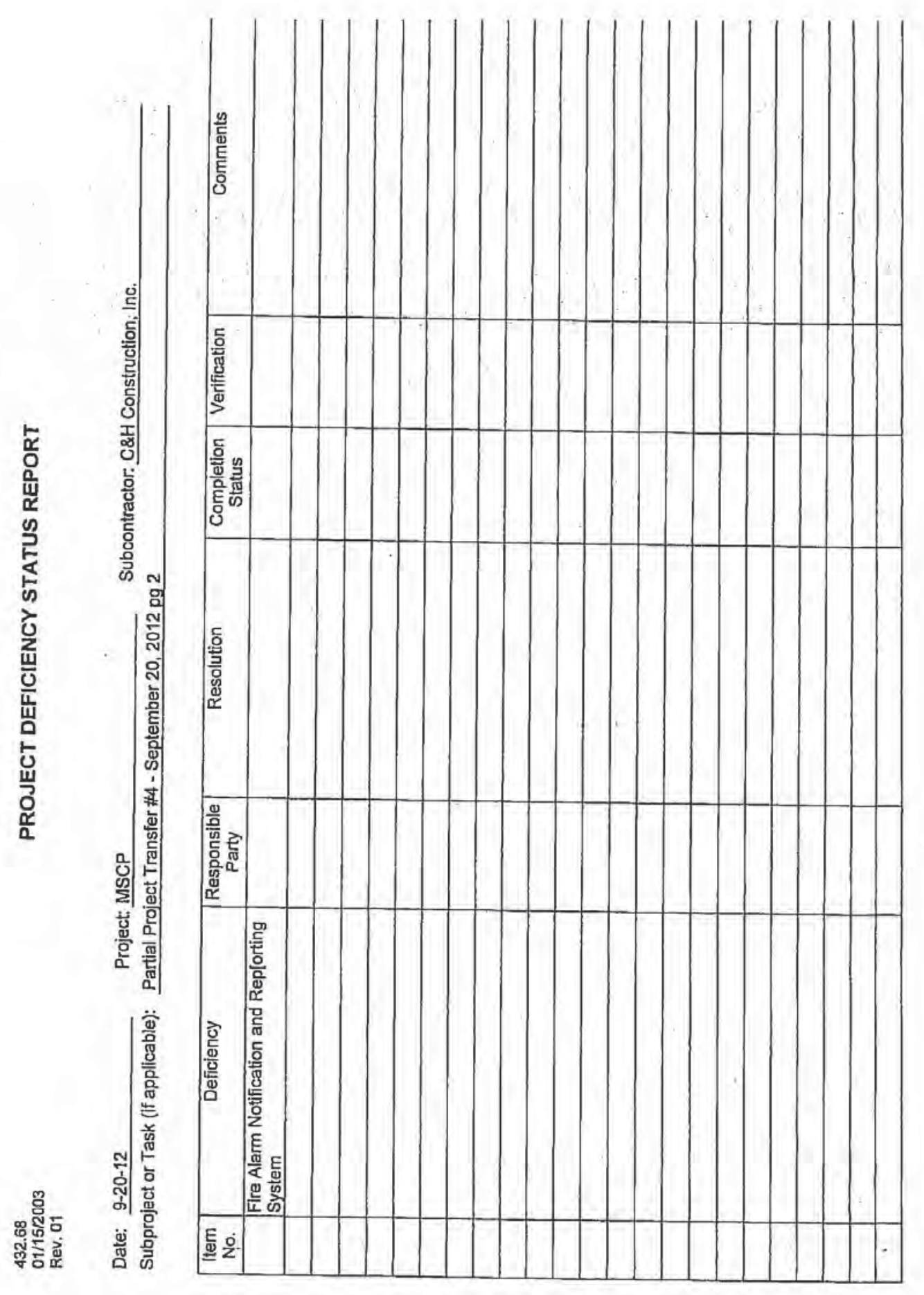




\section{MATERIAL SECURITY AND CONSOLIDATION PROJECT}

\section{Checklist for Baseline Final Project Transfer R1 (see exclusions noted in checklist)}

\begin{tabular}{|c|c|c|c|c|}
\hline \multirow{2}{*}{\multicolumn{2}{|c|}{$\begin{array}{l}\text { Deliverable or Activity } \\
\text { This is the Final Project Transfer for all project work and installed systems. } \\
\text { This Final Poject Transfer notes that two on going warranty issues; } \\
\text { 1.) Criticality Detection and Alarm System head replacement and training, controlled by } \\
\text { NCR Number } 5089 \text {. } \\
\text { 2.) HEPA System Variable Speed Controller in CPP-651, controlled by NCR Number } \\
\text { 5087. }\end{array}$}} & \multicolumn{3}{|c|}{ Completed? } \\
\hline & & Yes & \multirow{2}{*}{ No } & \multirow{2}{*}{ NA } \\
\hline 1. & $\begin{array}{l}\text { Applicable construction subcontractor equipment testing and System Operability } \\
\text { (SO) testing performed and test results approved. }\end{array}$ & $\mathrm{x}$ & & \\
\hline 2. & $\begin{array}{l}\text { Drawings including as-builts of essential and master facility drawings are } \\
\text { complete. }\end{array}$ & $x$ & & \\
\hline 3. & $\begin{array}{l}\text { Submittal of project documents needed for operation (vendor data, spare parts, } \\
\text { preventive mnintenance, etc.) to the System Engineer's organization. }\end{array}$ & $x$ & & \\
\hline 4. & $\begin{array}{l}\text { Occupancy requirements completed such as: } \\
\text { - Signs } \\
\text { - } \text { Access restrictions } \\
\text { - Labonal protective equipment } \\
\text { - Other safety equipment. }\end{array}$ & $\mathrm{x}$ & & \\
\hline 5. & $\begin{array}{l}\text { Punch-list items (listed in the "Deficiencies" section of Form } 423.04 \text { ) have been } \\
\text { completed or transferred to a deficienoy tracking system. }\end{array}$ & $x$ & & \\
\hline 6. & Inspection plans completed and closed. & $\mathrm{X}$ & & \\
\hline 7. & Engineering Job Form (EJ), completed. & $\mathrm{X}$ & & \\
\hline 8. & Environmental permits/regulatory notifications/documentation completed. & $\mathrm{X}$ & & \\
\hline 9. & $\begin{array}{l}\text { All required equipment identified and entered into the facility master equipment } \\
\text { list, "Master Equipment List and Maintenance History." }\end{array}$ & $\mathrm{X}$ & & \\
\hline 10. & Approved and issued Maintenance work orders as they become due. & $\mathrm{X}$ & & \\
\hline I1. & $\begin{array}{l}\text { Personnel training requirements are established and complete. This includes } \\
\text { system configuration for maintenance personnel. }\end{array}$ & $x$ & & \\
\hline 12. & Maintenance personnel training plans developed. & $\mathrm{X}$ & & \\
\hline 13. & Maintenance personnel training completed. & $\mathrm{X}$ & & \\
\hline 14. & Maintenance work orders are complete and ready for use & $\mathrm{X}$ & & \\
\hline 15. & $\begin{array}{l}\text { Notification fo plant shift supervisors on the configuration and operational changes } \\
\text { being implemented. }\end{array}$ & $x$ & & \\
\hline 16. & Notilication to Fire Department of project turnover. & $\mathrm{X}$ & & \\
\hline 17. & Responsibility for warranty work is transferred to the facility & $\mathrm{x}$ & & \\
\hline 18. & Required/critical spare parts are available & $\mathrm{X}$ & & \\
\hline 19. & Emergency management requirements have been updated & $\mathrm{x}$ & & \\
\hline
\end{tabular}

Appendix B 


\section{INSPECTION}

PROJECT TITLE: Material Security Consolidation Project (MSCP)

as constructed by

C\&H Construction, Inc.

The project (or portion of the project) was found by the Project Team (signatures as shown below) to be complete in accordance with the contraclual documents except for such deficiencies specifically noled below. The project (or portion of the project) is ready for testing and slart-up activities.

Deficiencies (attach list if necessary):

Commenis:

This is the Final Project Transfer for all project work and installed systems.

This Final Poject Transfer notes that two on going warranty issues:

1.) Criticality Detection and Alarm System head replacement and training, controlled by NCR Number 5089.

2.) HEPA System Variable Speed Controller in CPP-651, controlled by NCR Number 5087.

PROJECT TEAM APPROVAL

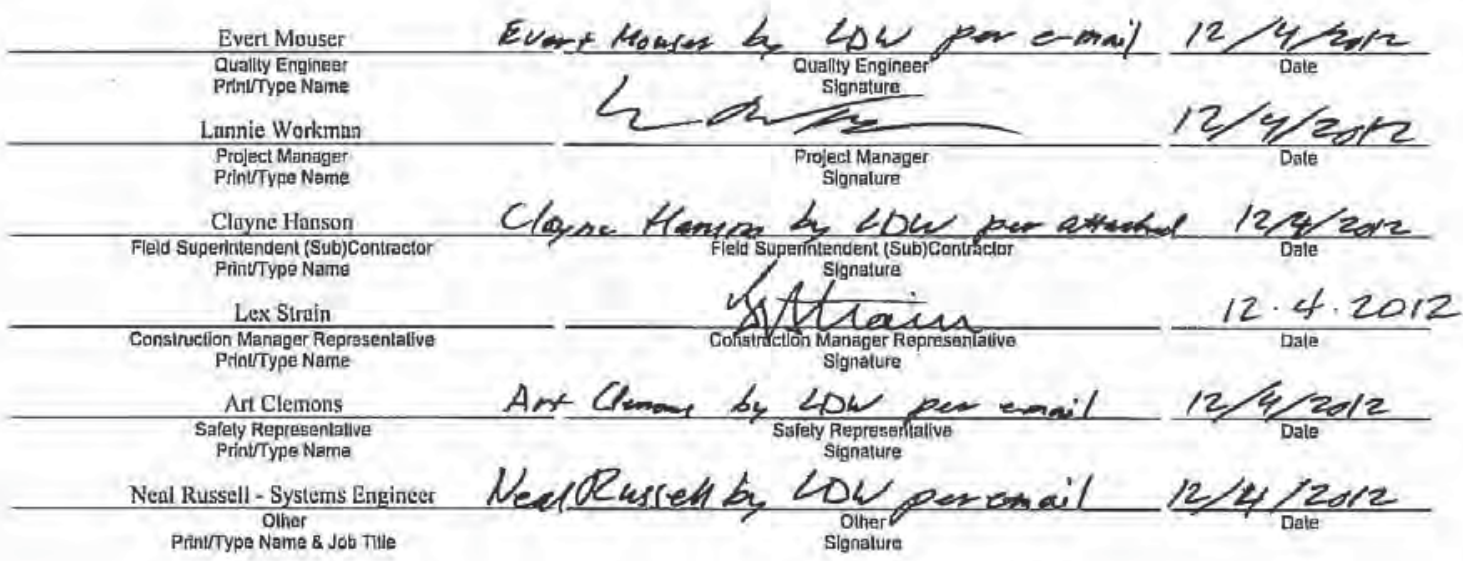




\section{PARTIAL PROJECT TRANSFER TO FACILITY MANAGER}

I certify that our persannel have monitored the design, fabrication, and installation of the project (or portion of the project) and, to the best of my knowledge, the work has been completed in accordance with the plans and technical specifications, including all approved changes. The project (or portion of the project) is hereby ready to be turned over to the Facility Manager for system operational tesling and other activities in preparation for final project transfer.

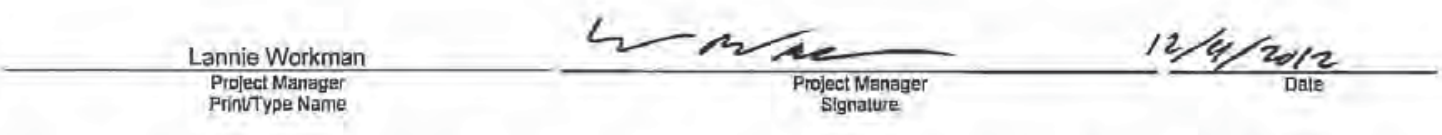

The MFC Nuclear Operations

Facility Organization hereby accepts total responsibility for maintenance and custody of the project (or portion of the project) and for coordination of remaining testing and activities required to prepare for final project transfer.

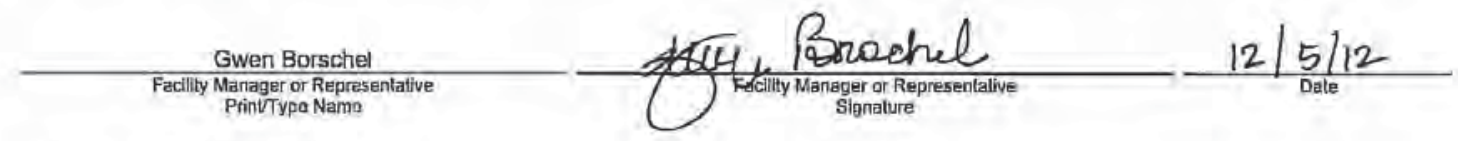

\section{INTERIM DISTRIBUTION}

Signatories, Land/Facility Operations, and Project File. For capital-funded projects include Property Accounting and Property Management.

WORK COMPLETION

\section{SUBCONTRACTORIDIRECT HIRE:}

I cerlify on behalf of C\&H Construction, Inc.

subject to the penaltes provided under 18 U.S.C., Section 1001, that our personnel have accomplished the contract work and, to the best of my knowledge, the work was performed or accomplished in accordance with the contractual documents, including all approved changes,

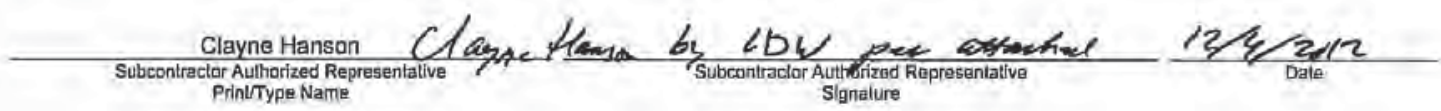

I certify that the administration of the contract for the above named project is, to the best of my knowledge, compiete to the extent required for this Project Transfer and/or close out of the contract

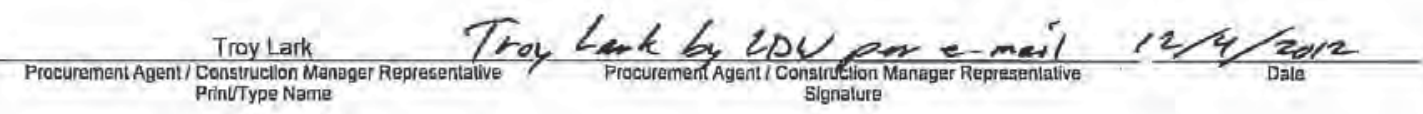


I certify completion of final testing and project revlew to ensure project requirements have been met in accordance with the Tumover and Acceplance Plan. The project (or portion of the project) is hereby ready to be turned over lo the Facility Manager for acceptance.

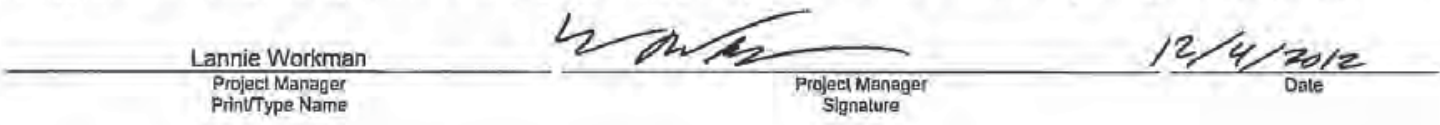

The project (or portion of the project) is hereby accepled for the Government.

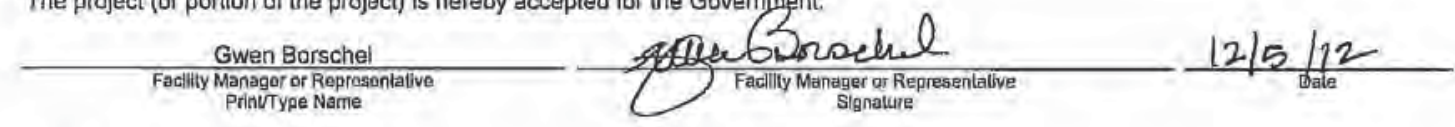

\section{FINAL DISTRIBUTION}

Signatories, plus DOE-ID Project Manager, Projecl File, and Land/Facility Operations, For capital-funded projects, include Property Accounting. Property Management, and Financial Construclion Coordinator.

\section{INSTRUCTIONS}

In accordance wilh MCP-2869, "Project Tumover and Acceplance," this form documents the final inspection between the subcontractorl direct hire and the Facility Manager, and effects partial and final transfers of the project (or portion of the project) to the Facllity Manager

\section{INSPECTION}

1. The inspection" section is to be used for both partlal and final project transfers. In general, a partial project transfer occurs when the contract or a specific and definable portion of the project has been completed and is to be turned over to the Facility Manager for custody and maintenance. Items such as SO Testing, Life Safety System tie-ins, terminations, and final project documentation still remain to be accomplished.

2. The description needs to be detailed and clear on what is being transferted (e.gn, reference drawing list, equipment list).

3. Deficiencies should only be allowed for partial transfers. If possible, include planned completlon date for each deficiency.

4. Quality Engineer signs for quality significant projects, Field Engineer signs for Consumer Grade projects, or bolth sign for projects that are combined activities.

\section{PARTIAL PROJECT TRANSFER APPROVAL}

1. The "Partial Project Transfer to Facility Manager" section is to be filled out for partial project transfer of the project (or portion of the project) from the subcontractor/direct hire to the Facility Manager after review by the Project Turnover Review Committee demonstrates that the project (or portion of the project) is safe and ready for occupancy and SO Testing activities.

\section{WORK COMPLETION}

1. The "Work Completion" section is to be filled out to cerlify contract work is complete. This is to be done in conjunction with the Final Project Transfer.

\section{FINAL PROJECT TRANSFER APPROVAL}

1. The "Final Project Transfer" section is to be filled out after final testing (such as SO testing), completion of all remaining project activities, and review by the Project Turnover Review Committee demonstrate that the project (or portion of the project) is ready for acceplance by the Facility Managerluser organization.

2. Use of this form does not constltute slart-up approval of the project or portion thereof. 


\begin{tabular}{lll} 
NSPECTION & $\begin{array}{l}\text { Partial } \\
\text { Final } \\
\text { Project (MSCP) }\end{array}$ & \\
\cline { 2 - 3 } & & \\
Project Number
\end{tabular}

PROJEGT TITLE: Material Security Consolidation Prolect (MSCP)

as constructed by

C\&H Construction Group Inc.

(Name of Subcontractor or Q Q reot Hira)

119824

(SubecentractiNo,

(Funding No./Req. No)

The project (or portion of the project) was found by the Project Team (signatures as shown below) to be complete in accordance with the contractual docurnents except for such deficlencies speciflcally noted below. The project (or portion of the project) is ready for lesilng and start-up activities.

Deficiencles (atlach list if necessary):

Commenis:

This is the Final Project Transfer for all project Work and inslalled systems.

This Final Pojecl Transfer noles that two on going warranly issues:

1.) Criticality Delection and Alerm Syslem head replacement and training, conltolled by NCR Number 5089.

2.) HEPA System Variable Speed Controller in CPP-651, controlled by NCR Number 5087.

\section{PROJECT TEAM APPROVAL}

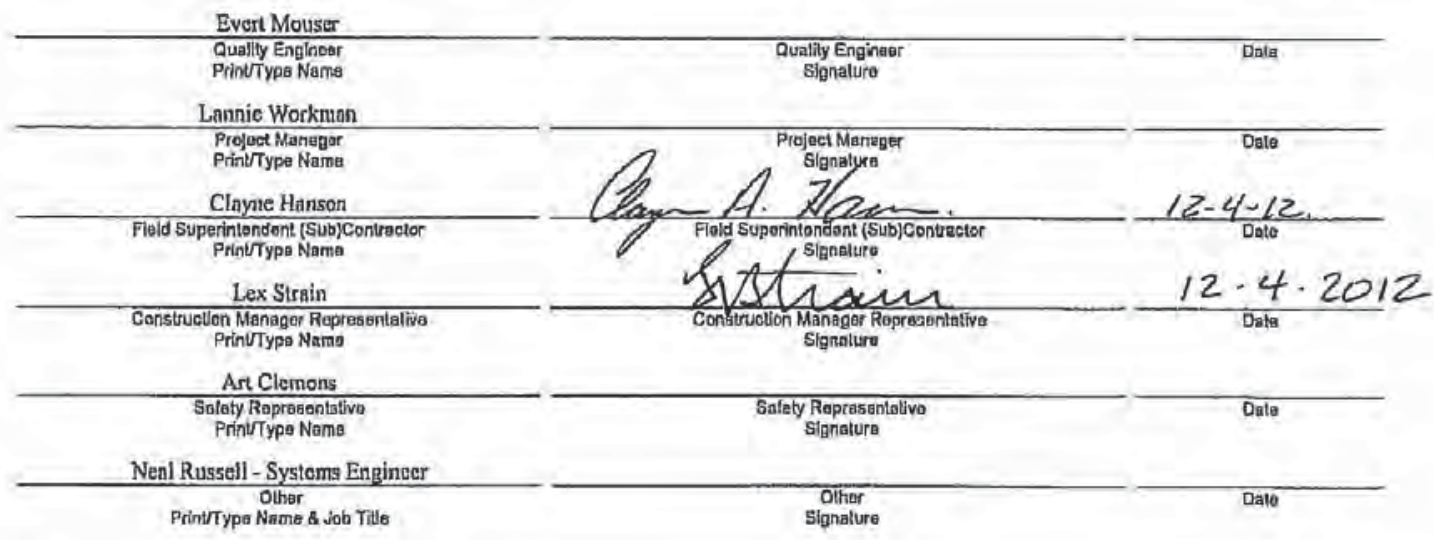




\section{PARTIAL PROJECT TRANSFER TO FACILITY MANAGER}

I cerlify that our personnel have monitored the design, fabrication, and installation of the project (or portion of the project) and, to the best of my knowledge, the work has been compleled in accordance with the plans and technical specifications, including all approved changes. The project (or portlon of the project) is hereby ready to be turned over to the Facility Manager for system operatlonal testing and other actlvílies in preparation for final project Iransfer.

Lannle Workman

$$
\text { Project Manager }
$$

PrinuTypo Name

\section{Projact Manager}

Signalure
Dat

Facillty Organizalion hereby accepts total resporisibility for malntenance and custody of

The MFC Nuclear Operallons coordination of remaining testing and activilies required to prepare for final projecl iransfer.

Gwen Borschel

Fgcility Managor or Raprogen

PrineTypa Nama

Facility Manaper or Representative

Dato

Slgnature

INTERIM DISTRIBUTION

Signatories, Land/Facility Operations, and Projecl File. For capital-funded projects include Property Accounting and Property Management.

\section{WORK COMPLETION}

\section{SUBCONTRACTORIDIRECT HIRE:}

I cerlify on behalf of C\&H Constructlon Group, Inc.

subject to the penelties provided under 18 U.S.C., Section 1001, that our personnel have accomplished the contract work and, to the best of my knowledge, the work was performed or accomplished in actordance with the contractual documents, including all approved ehanges.

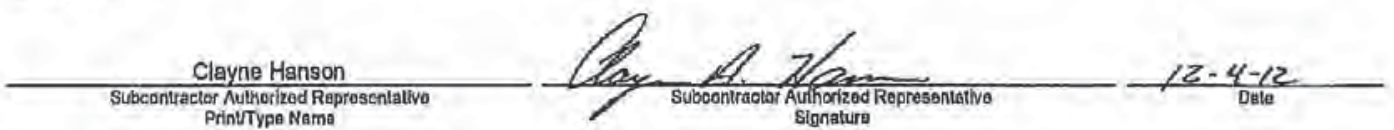

I certify thal the administration of the contract for the above named project is, to the best of my knowledge, complete to the extent required for this Project Transfer and/or close out of the coniraci

Procurement Agent / Consiruction Maniager Represuntalive
PrintType NamB


I certify completion of final tesling and projecl review to ensure projecl requirements have been met in accordance wilh the Turnover and Acceptance Plan. The project (or portion of the project) is hereby ready to be turned over to the Facility Manager for acceptance.

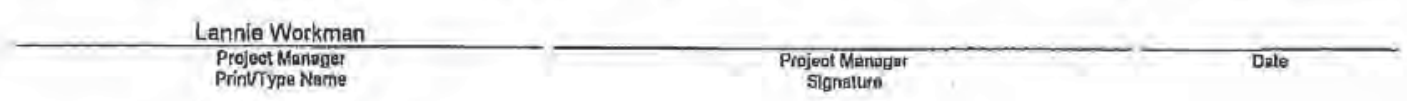

The project (or portlon of the project) is hereby accepled for the Government.

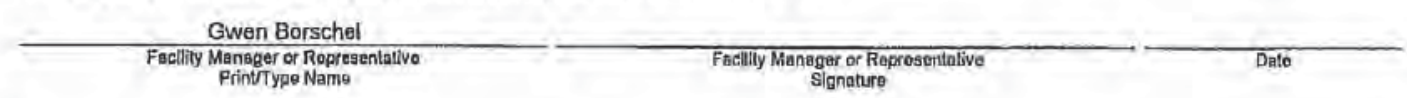

FINAL DISTRIBUTION

Signatories, plus DOE-ID Project Manager. Projed File, and Land/Facility Operatlons, For capital-funded projecis, Include Property Accounting, Properly Management, and Finencial Construction Coordinator.

\section{INSTRUCTIONS}

In accordance with MCP-2889, "Project Tumover and Acceplance," Inis form doouments the final inspectlon between the subconlraclorl direct hire and the Facility Manager, and effects partial and final Iransfers of the project (or portion of the project) 10 the Facility Manager.

\section{INSPECTION}

1. The "Inspection" section is !o be used for bolt parlial and final project Iransfers, In general, a partial project transfer occurs when the coniract or a speclfic and definable portion of the project has been completed and is to be turned over to the Facillty Manager for custody and maintenance. Items such as SO Testing, Life Safely System fle-ins, lerminalions, and final project documentation stlll remain to be accomplished.

2. The description needs to be detailed and clear on what is being transferred (e.g., reference drawing llst, equlpment list).

3. Deficlencles should only be allowed for parlial transfers. If possible, include planned completlon date for each deficiency.

4. Qualliy Engineer signs for quality signilieant projecls, Field Engineer signs for Consumer Grade projecis, or both sign for projocts that are combined activities.

\section{PARTIAL PROJECT TRANSFER APPROVAL}

1. The "Partial Project Transfer to Facility Manager" section is to be filled out for partial project transfer of the projegt (or porlion of the project) from the subcontractor/direct hire to the Facllity Manager after review by the Project Turnover Review Commlitee demonstrales that the project (or portion of the projeci) is safe and ready for occupancy and so Testing actlvities.

\section{WORK COMPLETION}

1. The "Work Completion" sectlon is to be filled out fo cerlify contract work is complete. This is to be done In conjunction with Ihe Final Projecl Transfer.

\section{FINAL PROJECT TRANSFER APPROVAL}

1. The "Final Project Transfer" section is to be filled out after final lestlng (such as SO testing), completion of all remaining project activities, and revlew by the Project Turnover Review Committee demonstrate that the project (or portion of the project) is ready for acceptance by the Facility Manager/user organization.

2. Use of this form does not consiltule starl-up approval of the project or portion thereof. 
Re: Final Project Transfer, MSCP, CPP-651. - lannie.workman@inl.gov - Idaho National ... Page 1 of 1

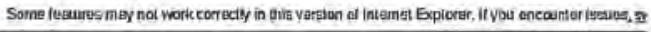

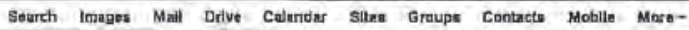

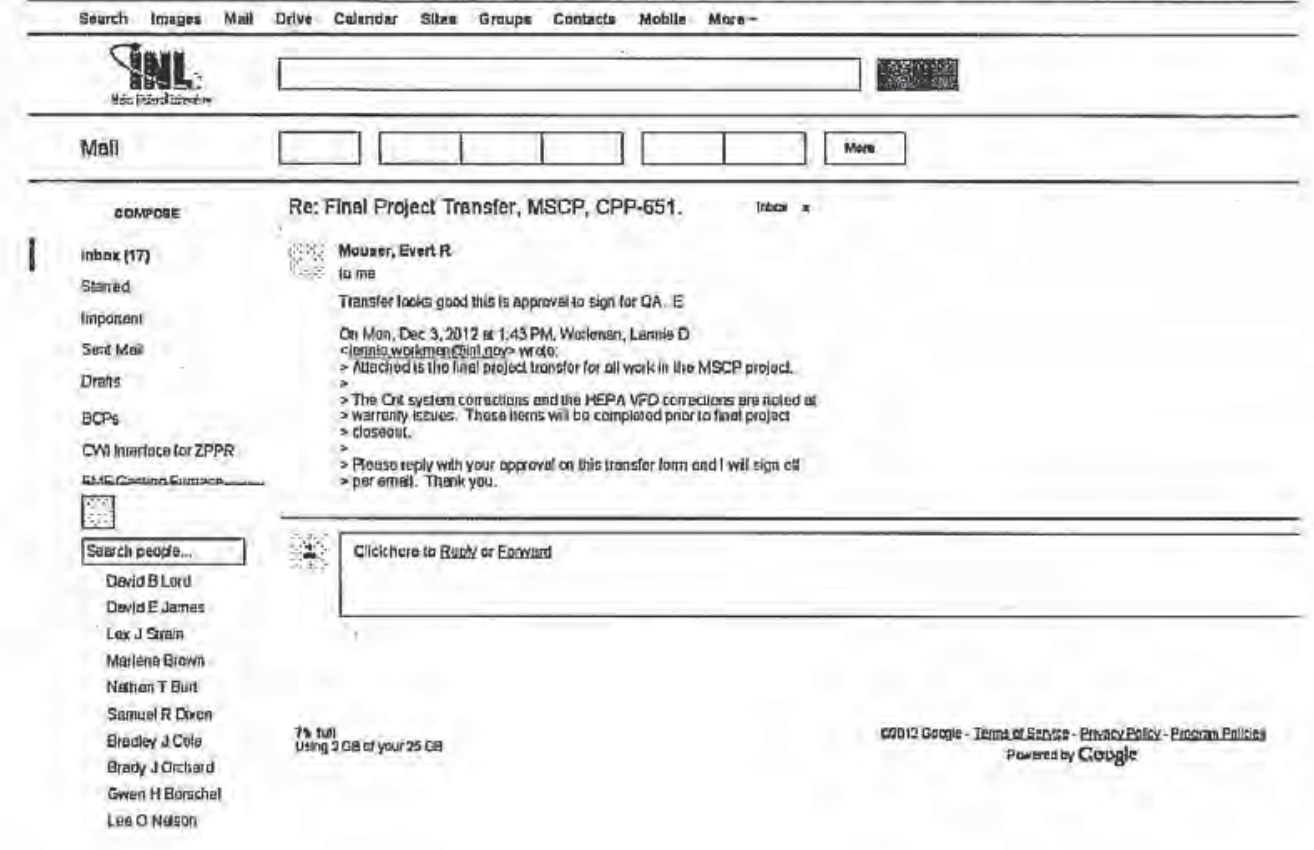


Re: Final Project Transfer, MSCP, CPP-651. - lannie.workman@inl.gov - Idaho National ... Page 1 of 1

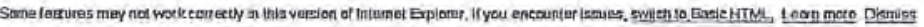

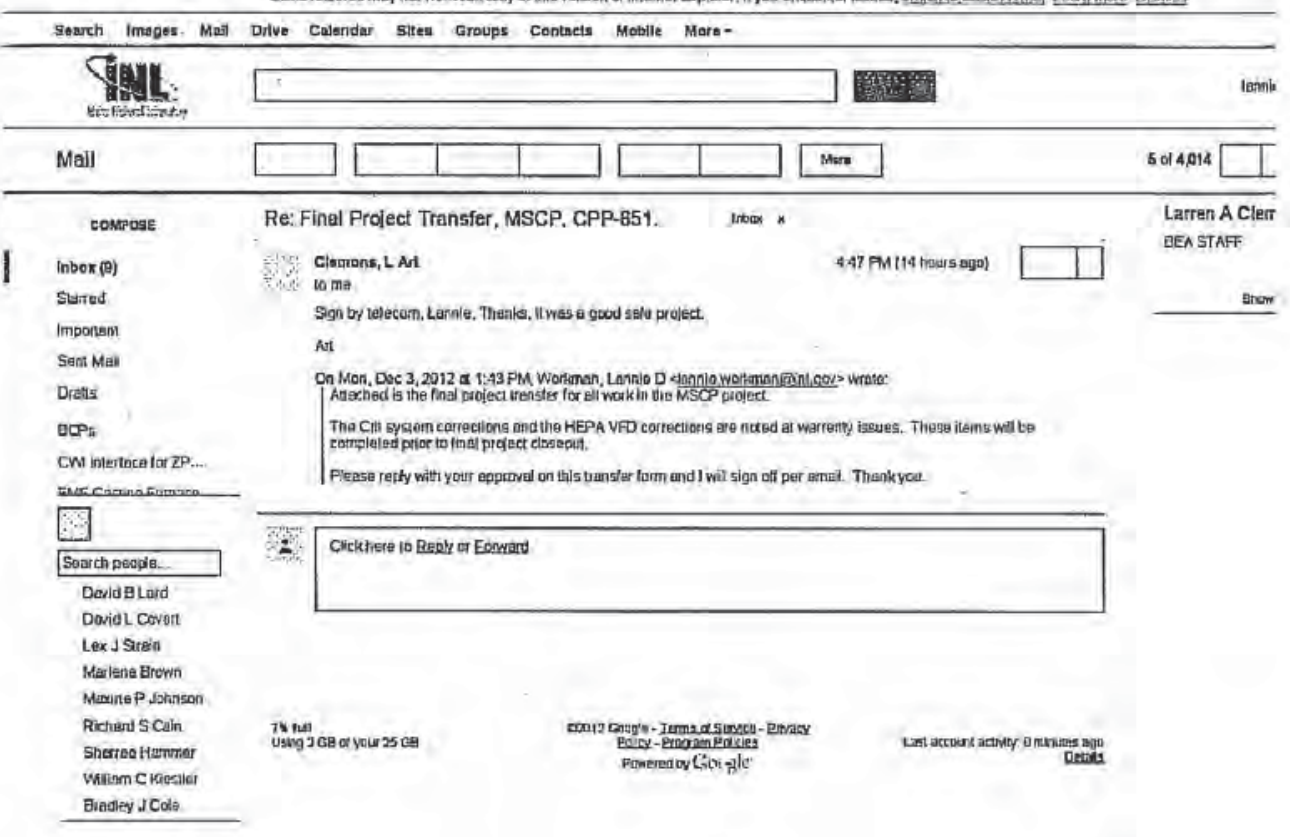

https://mail.google.com/mail/u/0/?shva=1 
Re: Final Project Transfer, MSCP, CPP-651. - lannie.workman@inl.gov - Idaho National ... Page 1 of 1

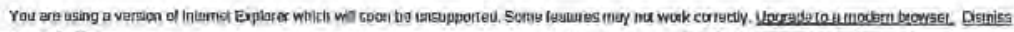

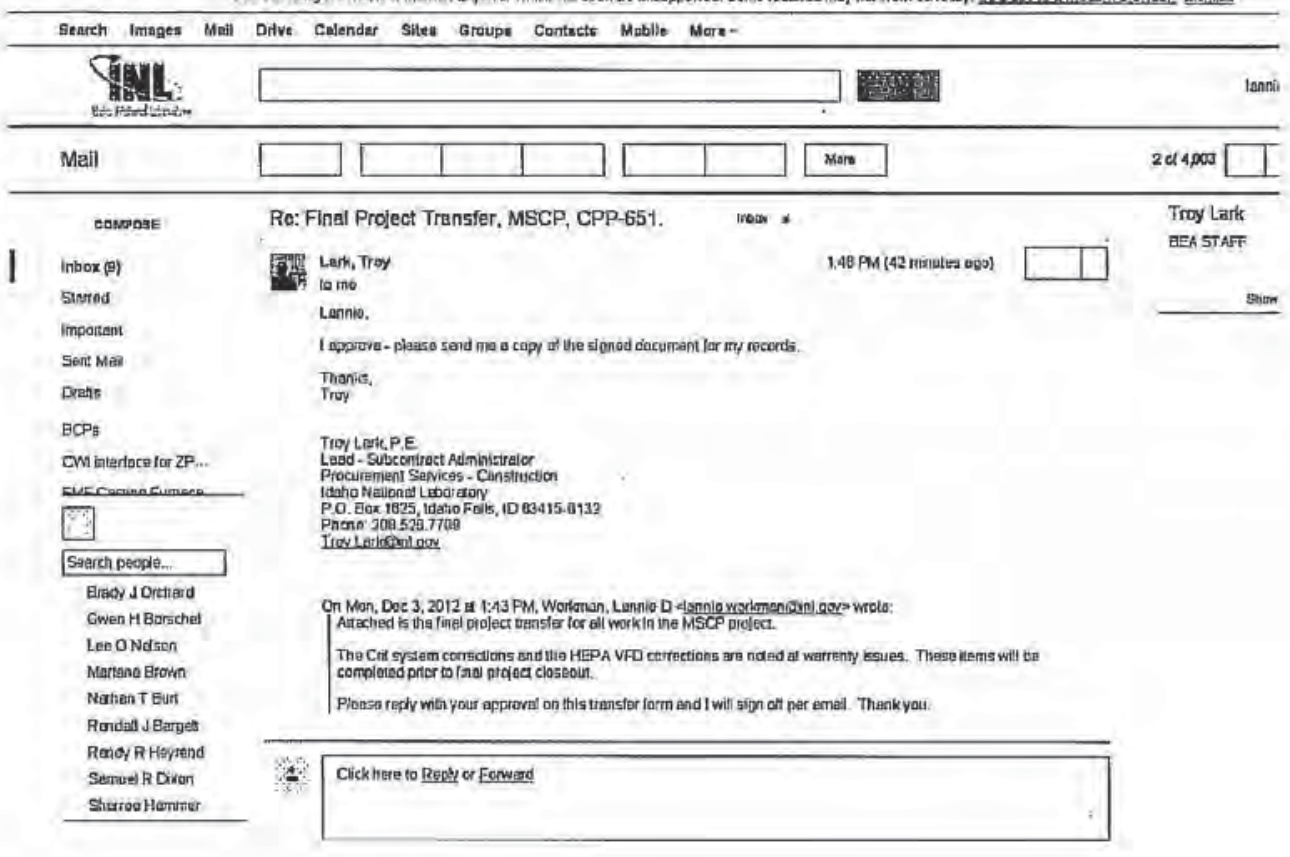


Re: Final Project Transfer, MSCP, CPP-651 - lannie.workman@inl.gov - Idaho National ... Page 1 of 1

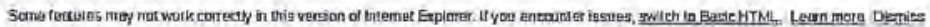

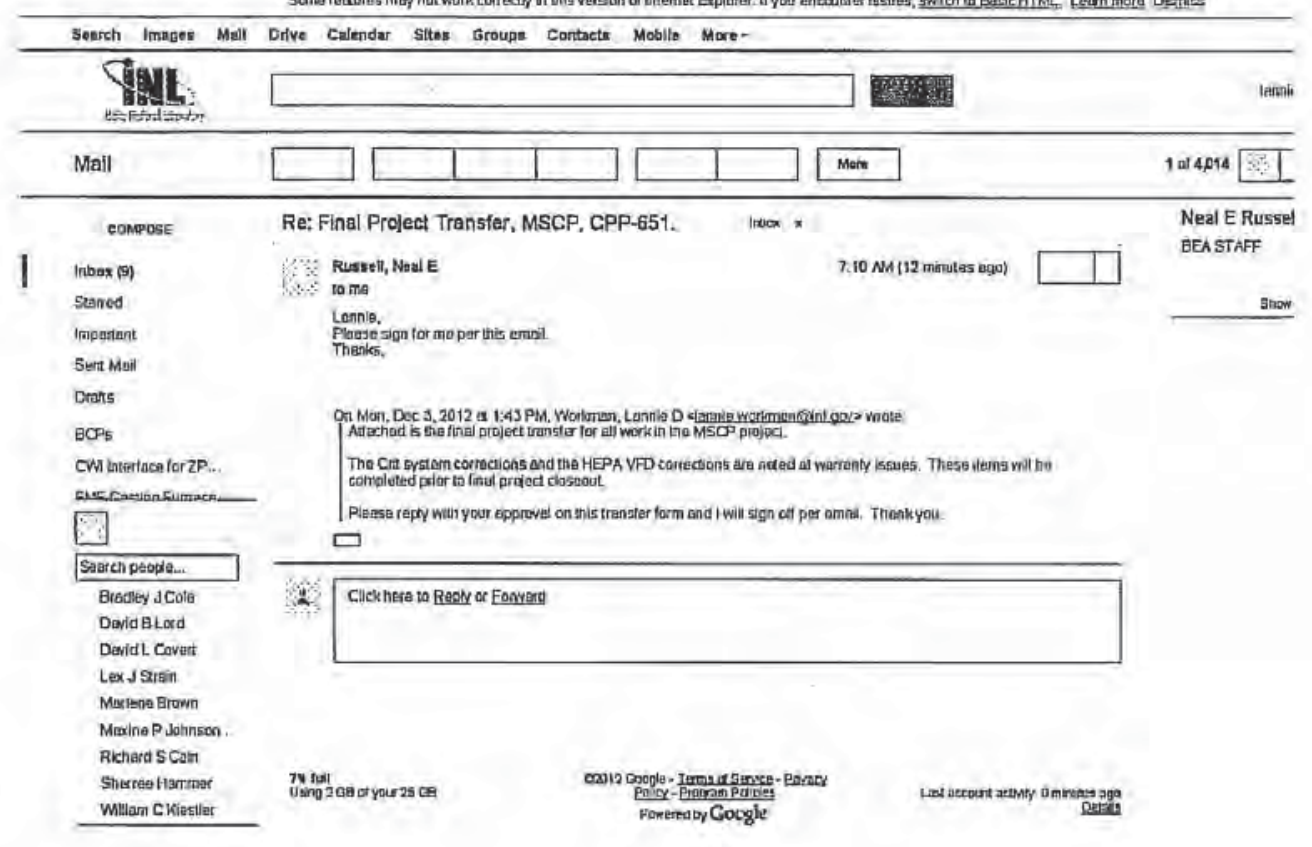

https://mail.google.com $/ \mathrm{mail} / \mathrm{u} / 0 / 7$ shva $=1$

$12 / 4 / 2012$ 


\section{Appendix F, Cost Closing Statement}

130.01

$10 / 01 / 99$

Rev. 01

\author{
PROJECT COMPLETION \& \\ COST CLOSING STATEMENT
}

To: Those Listed Below

Project: Material Security and Consolidation Project

Current PA No.: N/A B\&RC No.: $39 \mathrm{FS} 20000$

EA No:: 920124

I certify that all work required under the subject authorization, as amended, was completed on April, 2013

Battelle Energy Alliance
Battelle Energy Alliance
COST SUMMARY

Contract No's. Or Other References

Cost(s)

Oracle\# 92012409 Mat'l Security \& Consolidation

$\$ 11,151,997$

Total Costs

$\$ 11,151,997$

Demolition Costs

\$ 132,266

Addresses:

DOE-ID

Idaho Operations Office

1955 Fremont Avenue

Idaho Falls, ID 83415

\section{M\&O Contractor}

Battelle Energy Alliance, LLC

P.O. Box 1625

Idaho Falls, ID 83415-3898 